\title{
LAW AND FINANCE
}

\author{
Rafael La Porta \\ Florencio Lopez-de-Silanes \\ Andrei Shleifer \\ Robert W. Vishny
}

NBER Working Paper 5661

\section{NATIONAL BUREAU OF ECONOMIC RESEARCH 1050 Massachusetts Avenue \\ Cambridge, MA 02138 \\ July 1996}

We are grateful to Mark Chen, Steven Friedman, Magdalena Lopez-Morton, and Katya Zhuravskaya for excellent research assistance, to Robert Barro, Edward Glaeser, Zvi Griliches, Oliver Hart, Martin Hellwig, James Hines, Louis Kaplow, Raghu Rajan, Luigi Zingales, the participants of the Harvard Law School and Catholic University of Milan Law and Economics Seminars, and especially Professor Francesco DeNozza for comments, and to the NSF, the NBER and the HIID for financial support of this research. This paper is part of NBER's research program in Corporate Finance. Any opinions expressed are those of the authors and not those of the National Bureau of Economic Research.

(C) 1996 by Rafael La Porta, Florencio Lopez-de-Silanes, Andrei Shleifer and Robert W. Vishny. All rights reserved. Short sections of text, not to exceed two paragraphs, may be quoted without explicit permission provided that full credit, including $(\mathcal{C}$ notice, is given to the source. 
NBER Working Paper 5661

July 1996

\title{
LAW AND FINANCE
}

\begin{abstract}
This paper examines legal rules covering protection of corporate shareholders and creditors, the origin of these rules, and the quality of their enforcement in 49 countries. The results show that common law countries generally have the best, and French civil law countries the worst, legal protections of investors, with German and Scandinavian civil law countries located in the middle. We also find that concentration of ownership of shares in the largest public companies is negatively related to investor protections, consistent with the hypothesis that small, diversified shareholders are unlikely to be important in countries that fail to protect their rights.
\end{abstract}

Rafael La Porta

Department of Economics

Harvard University

Cambridge, MA 02138

Andrei Shleifer

Department of Economics

Littauer 315

Harvard University

Cambridge, MA 02138

and NBER
Florencio Lopez-de-Silanes

Kennedy School of Government

Harvard University

79 JFK Street

Cambridge, MA 02138

and NBER

Robert W. Vishny

Graduate School of Business

The University of Chicago

1101 East 58th Street

Chicago, IL 60637

and NBER 
1. Overview of the issues.

In traditional finance of Modigliani and Miller (1958), securities are recognized by their cash flows. For example, debt has a fixed promised stream of interest payments, whereas equity entitles its owner to receiving dividends. Recent financial research has shown that this is far from the whole story, and that the defining feature of various securities is the rights that they bring to their owners (see, e.g., Hart 1995). Thus shares typically give their owners the right to vote for directors of companies, whereas debt entitles creditors to, for example, the power to repossess collateral when the company fails to make promised payments.

The rights attached to securities become tremendously important once it is recognized that managers of companies act in their own interest. Investors' rights give them the power to extract from these managers the returns on their investment. Thus shareholders receive dividends because they can vote out the directors who do not pay them, and creditors are paid because they have the power to repossess collateral. Without these rights, investors would not be able to get paid, and therefore firms would not have the benefit of raising funds from these investors. The rights attached to securities are what managers and entrepreneurs give up to get finance.

But the view that securities are inherently characterized by some intrinsic rights is incomplete as well. It ignores the obvious point that these rights depend on the legal rules of the jurisdictions where these securities are issued. Does being a shareholder in France give an investor the same privileges as being a shareholder in the United States, India, or Mexico? Would a secured creditor in Germany fare as well when the borrower defaults as one in Taiwan or Italy, assuming that the value of the collateral is the same in all cases? Law and the quality of its enforcement are potentially important determinants of what rights security holders have and how 
well these rights are protected. Since the protection investors receive determines their readiness to finance firms, corporate finance may critically turn on these legal rules and their enforcement. Indeed, the differences in legal protections of investors might help explain why firms are financed and owned so differently in different countries. Why do Italian companies rarely go public (Pagano, Panetta and Zingales 1995)? Why does Germany have such a small stock market, but also maintains very large and powerful banks (Edwards and Fischer 1994)? Why is the voting premium -- the price of shares with high voting rights relative to that of shares with low voting rights -- small in Sweden and the United States, and much larger in Italy and Israel (Levy 1982, Rydquist 1987, Zingales 1994, 1995)? Indeed, why were Russian stocks nearly worthless immediately after privatization -- by some estimates one hundred times cheaper than Western stocks backed by comparable assets -- and why did Russian companies have virtually no access to external finance (Boycko, Shleifer and Vishny 1993)? Why is ownership of large American and British companies so widely dispersed (Berle and Means 1932)? The content of legal rules in different countries may well shed light on these corporate governance puzzles.

In recent years, economists and legal scholars have begun to examine theoretically the costs of benefits of alternative legal rules regarding investor rights (e.g., Bebchuk 1995, Bebchuk and Zingales 1995, Gromb 1993, Grossman and Hart 1988, Harris and Raviv 1988). The trouble is, there are no systematic data available on what the legal rules pertaining to corporate governance are around the world, how well these rules are enforced in different countries, and what effect these rules have. There is no systematic knowledge, for example, of whether different countries actually do have substantially different rules that might explain differences in their financing patterns. Comparative statistical analysis of the legal underpinnings of corporate finance 
-- and commerce more generally -- remains unchartered territory.

In this paper, we attempt to explore this territory. We examine empirically how laws protecting investors differ across countries, how quality of enforcement of these laws varies, and whether these variations matter for corporate ownership patterns around the world.

Our starting point is the recognition that laws in different countries are typically not written from scratch, but rather transplanted -- voluntarily or otherwise -- from a few legal families or traditions (Watson 1974). In general, commercial laws come from two broad traditions: common law and civil law. Legal rules of civil law countries are derived from Roman Law, and "are conceived as rules of conduct intimately linked to ideas of justice and morality" (David and Brierley 1985, p. 22). These rules are usually developed by legal scholars, and incorporated into commercial codes. In contrast, common law is British in origin, and was "formed primarily by judges who tried to resolve specific disputes" (David and Brierley, p. 24). Furthermore, there are only three major civil law traditions or families that modern commercial laws originate from: French, German, and Scandinavian. The French and the German civil traditions, as well as the common law tradition, have spread around the world through a combination of conquest, imperialism, outright borrowing, and more subtle imitation. The resulting laws reflect both the influence of their families and the revisions specific to individual countries. As a result of this spread of legal families and the subsequent evolution of the laws, we can compare both the individual legal rules and whole families across a large number of countries.

To this end, we have assembled a data set covering legal rules pertaining to the rights of investors, and to the quality of enforcement of these rules, in 49 countries that have publicly traded companies. For shareholders, some of the rules we examine cover voting powers, ease of 
participation in corporate voting, and legal protections against expropriation by management. For creditors, some of these rules cover the respect for security of the loan, the ability to grab assets in case of a loan default, and the inability of management to seek protection from creditors unilaterally. In effect, these rules measure the ease with which investors can exercise their powers against management. We also consider measures of the quality of enforcement of legal rules in different countries and of the quality of their accounting systems. These data allow us to tell which countries protect what types of investors, and how well they do it. We can also find out how much of the differences between national laws is explained by the legal origin of these laws.

Our analysis yields some striking results. To begin, laws differ a great deal across countries: an investor in France has very different legal rights than she does in Britain or Taiwan. Moreover, a large part of this variation is accounted for by differences in legal origin. Civil laws give investors weaker legal rights than common laws do. The most striking difference is between common law countries, which give both shareholders and creditors the -- relatively speaking -strongest protections, and French civil law countries, which protect investors the least. German civil law and Scandinavian countries fall between common law and French civil law countries in the strength of legal investor protection. The quality of law enforcement is the highest in Scandinavian and German civil law countries, next highest in common law countries, and again the lowest in French civil law countries. Finally, these results are not just a consequence of different income levels in countries with different laws. All the evidence thus suggests the weakness of the legal protections afforded investors in French civil law countries compared to those in common law countries, regardless of income levels.

But showing that law and its enforcement varies across countries and legal families is only 
the beginning of the story. The next question is how do the countries with poor laws or their enforcement cope with this problem? Do their firms get no financing at all, or do these countries have other, substitute mechanisms of corporate governance? These mechanisms may be in fact incorporated into the law, or they may lie outside the law. In addition to establishing the significant differences in investor protection across legal systems, this paper begins to examine some of the possible adaptations to the lack of investor protection.

One potential adaptation to fewer laws is strong enforcement of laws, but as we pointed out above this does not appear to be the case empirically. Another possible -- legal -- adaptation, which legal scholars sometimes refer to as "bright line" rules, is to legally introduce mandatory standards of retention and distribution of capital to investors, which limit the opportunities for managerial expropriation. Indeed, we find that French civil law countries are more likely to have such bright line legal rules, namely mandatory dividends and maintenance of legal capital reserves, than the rest of the countries.

Perhaps the most interesting adaptation to the lack of legal protections that we examine is ownership concentration. Some concentration of ownership of a firm's shares is typically efficient to provide managers with an incentive to work, and large investors with an incentive to monitor the managers (Jensen and Meckling 1976, Shleifer and Vishny 1986). However, some dispersion of ownership among small investors is also desirable to diversify risk. As argued by Shleifer and Vishny (1996), ownership concentration may actually become excessive when small investors do not have enough legal rights to secure a return on their investment, and hence avoid holding shares. When the law protects investors, they can remain small and still hope to get something back on their money. When the law does not protect them, investors have to be large and 
powerful to stand up to the management and extract payments from them.

In this paper, we examine ownership concentration in the largest publicly traded companies in the countries in our sample, and find a strong negative correlation between concentration of ownership, as measured by the combined stake of the three largest shareholders, and the quality of legal protection of investors in a country. The substitute for poor investor protection in French civil: law countries is extremely concentrated ownership, and by consequence lack of significant public equity markets. The data on ownership concentration thus confirms the idea that legal systems matter for corporate governance, and that firms have to adapt to the limitations of the legal systems that they operate in.

The next section of the paper describes the countries and their laws. Sections 3 and 4 then compare shareholder and creditor rights, respectively, in different countries and different legal traditions. Section 5 compares the quality of law enforcement and accounting standards in different countries and legal traditions. Section 6 focuses on ownership. In section 7, we examine and reject the hypothesis that poverty accounts for poor investor protection, although the quality of legal enforcement clearly improves with income. Section 8 summarizes our findings.

2. Countries, Legal Families, and Legal Rules.

Countries

Most studies of corporate governance focus on one, or a few, wealthy economies (see, e.g., Rajan and Zingales 1995, Berglof and Perotti 1994, Gorton and Schmidt 1995, Kaplan and Minton 1994). However, corporate governance in all of the three economies that scholars typically focus on -- the United States, Germany, and Japan -- is quite effective. To understand 
better the role of legal protection of investors, we need to examine a larger sample of countries. To this end, we have assembled as comprehensive a sample as possible of countries that have some non-financial firms traded on their stock exchanges. The sample covers 49 countries from Europe, North and South America, Africa, Asia, and Australia. There are no socialist or "transition" economies in the sample. A country is selected for inclusion if, based on the WorldScope sample of 15,900 firms from 33 countries and the Moody's International sample of 15,100 non-U.S. firms from 92 countries, that country had at least five domestic non-financial publicly traded firms in 1993 . We restrict attention to countries that have publicly traded firms since our primary focus is on protecting investor rights, and without public shareholders a discussion of investor rights would be limited. Having at least five non-financial firms is also essential for construction of ownership data.

\section{Legal Families}

Comparative legal scholars agree that, even though no two nations' laws are exactly alike, some national legal systems are sufficiently similar in certain critical respects to permit classification of national legal systems into major families of law. Although there is no unanimity among legal scholars on how to define legal families, "among the criteria often used for this purpose are the following: (1) historical background and development of the legal system, (2) theories and hierarchies of sources of law, (3) the working methodology of jurists within the legal systems, (4) the characteristics of legal concepts employed by the system, (5) the legal institutions of the system, and (6) the divisions of law employed within a system" (Glendon et al 1992, pp. 4-

5). Based on this approach, scholars identify two broad legal traditions that pertain to matters 
discussed in this paper: civil law and common law ${ }^{2}$.

The civil, or Romano-Germanic, legal tradition is the oldest, the most influential, and the most widely distributed tradition around the world. It originates in Roman law, uses statutes and comprehensive codes as a primary means of ordering legal material, and relies heavily on legal scholars to ascertain and formulate its rules (Merryman 1969). Legal scholars typically identify three currently common families of laws within the civil law tradition: French, German, and Scandinavian. The French Commercial Code was written under Napoleon in 1807, and brought by his armies to Belgium, the Netherlands, part of Poland, Italy, and Western regions of Germany. In the colonial era, France extended her legal influence to the Near East and Northern and SubSaharan Africa, Indochina, Oceania, and French Caribbean islands. French legal influence has been significant as well in Luxembourg, Portugal, Spain, some of the Swiss cantons, and Italy (Glendon et al. 1994). When the Spanish and Portuguese empires in Latin America dissolved in the 19 th century, it was mainly the French civil law that the lawmakers of the new nations looked to for inspiration. Our sample contains 21 countries with laws in the French civil tradition.

The German Commercial Code was written in 1897 after Bismarck's unification of Germany, and perhaps because it was produced several decades later, was not as widely adopted as the French Code. It had an important influence on the legal theory and doctrine in Austria,

\footnotetext{
${ }^{2}$ The religious traditions, such as Jewish law, Canon Law, Hindu law, and Muslim law, appear to be less relevant in matters of investor protections. "Thus the Arabian countries unquestionably belong to Islamic law as far as family and inheritance law is concerned, just as India belongs to Hindu law, but economic law of these countries (including commercial law and the law of contract and tort) is heavily impressed by the legal thinking of the colonial and mandatory powers -- the Common Law in the case of India, French law in the case of most of the Arab States" (Zweigert and Kotz 1987, p. 66). We focus on the principal secular legal traditions in this study
} 
Czechoslovakia, Greece, Hungary, Italy, Switzerland, Yugoslavia, Japan and Korea. Taiwan's laws came from China, which borrowed heavily from the German Code during its modernization. We have 6 countries from this family in our sample.

The Scandinavian family is usually viewed as part of the civil law tradition, although its law is less derivative of Roman law than the French and German families (Zweigert and Kotz 1987). Although Nordic countries had civil codes as far back as the 18th century, these codes are not used any more. Most writers describe the Scandinavian laws as similar to each other but "distinct" from others, so we keep the 4 Nordic countries in our sample as a separate family.

The family referred to as the common law tradition includes the law of England and those laws modeled on English law. The common law is formed by judges who have to resolve specific disputes. Precedents from judicial decisions, as opposed to contributions by the scholars, shape common law. Common law has spread to British colonies, including the United States, Canada, Australia, India, and many other countries. There are 18 common law countries in our sample. Zweigert and Kotz (1987) offer a colorful characterization of the differences between common and civil law: "The tradition of the English Common Law has been one of gradual development from decision to decision: historically speaking, it is case law, not enacted law. On the Continent, the development since the reception of Roman law has been quite different, from the interpretation of the Justinian's Corpus Iuris to the codification, nation by nation, of abstract rules. So common law comes from the court, Continental Law from the study; the great jurists of England were judges, on the Continent professors. On the Continent lawyers, faced with a problem, even a new and unforeseen one, ask what solution the rule provides; in England and the United States they predict how the judge would deal with the problem, given existing decisions 
These differences in style run through the whole legal system. On the Continent lawyers think abstractly, in terms of institutions; in England concretely, in terms of cases, the relationship of the parties, 'rights and duties.' On the Continent, the system is conceived as being complete and free from gaps, in England lawyers feel their way gradually from case to case. On the Continent lawyers delight in systematics, in England they are skeptical of every generalization. On the Continent lawyers operate with ideas, which often, dangerously enough, take on a life of their own; in England they think in pictures; and so one could continue."

To classify countries into legal families, we rely principally on a publication of the American Association of Law Libraries called "Foreign Law: Current Sources of Codes and Basic Legislation in Jurisdictions Around the World" (Reynolds and Flores, 1989). In most cases, such classification is uncontroversial. In some cases, however, while the basic origin of laws is clear, laws over time have been amended to incorporate the needs of the adopting country as well as influences from other families. For example, although Ecuador is a French civil law country, its company law was revised in 1977 in part to incorporate some common law rules. After World War II, the American occupying army changed some Japanese laws, although their basic German civil law structure remained. While Italian laws originate in the French tradition, over years they had some German influence. In all these -- and several other -- cases, we have classified a country based on the original structure of the laws it adopted, rather than on the revisions.

One potential difficulty for our classification is posed by the attempt to harmonize West European laws currently underway in the European Community (Andenas and Kenyon-Slade 1993, Werlauff 1993). The Community has issued several directives designed to unify European commercial laws, including some of the laws that pertain to corporate governance. Several 
countries have changed their laws to adhere to EC directives. However, in most instances, the directives are not mandatory, and the countries are given some time to change their laws. Moreover, the EC directives accommodate a great deal of diversity between countries. As of 1993-1994 -- the point in time when we examine the legal rules of the countries in our sample -EC harmonization has not generally affected the legal rules that we focus on. The one area where the EC impact has been large, namely mergers and acquisitions, is not an area that we examine in this paper (see below).

\section{Legal Rules}

In this paper, we look at a fairly narrow range of differences between laws, namely those pertaining to investor protection. To this end, we examine two types of laws: company laws and bankruptcy/ reorganization laws. Company laws exist in all countries, and are concerned with (1) the legal relations between corporate insiders (members of the corporation, i.e., shareholders, directors) and the corporation itself; and (2) the legal relations between the corporation and certain outsiders, particularly creditors. Bankruptcy/ reorganization laws apply more generally than just to companies, but deal specifically with procedures that unfold in the case of failure to pay back debt. All these laws are part of the commercial codes in civil law countries, and exist as separate laws, mainly in the form of Acts, in common law countries.

Although the focus on these two sources of law gives us a lot of data, there are several conspicuous omissions from the data set. First, this paper says little about merger and takeover rules, except indirectly by looking at voting mechanisms. These rules are spread between company laws, anti-trust laws, security laws, stock exchange regulations, and sometimes banking 
regulations as well. Moreover, these rules have changed significantly in Europe as part of EC legal harmonization. Until now, takeovers have been an important governance tool mainly in a few civil law countries, although the situation may change. We defer an analysis of these rules to a separate paper.

Second, this paper also says little about disclosure rules, which again come from many sources, including company laws, security laws, and stock exchange regulations, and are also intended for harmonization across the European Community. One important caveat here is that we do look at the quality of accounting standards, which to a significant extent is a consequence of the disclosure rules.

Third, we do not in this paper use any information from regulations imposed by security exchanges. One instance where this is relevant is exchange-imposed restrictions on the voting rights for the shares that companies can issue if these shares are to be traded on the exchange.

Finally, a potentially important set of rules that we do not deal with here is banking and financial institution regulations, which might take the form of restricting bank ownership, for example. Much has been made of these regulations in the United States by Roe (1994). Again, we defer their codification and examination to future work.

An inspection of company and bankruptcy laws suggests numerous potentially measurable differences among countries. Here we focus only on some of the most basic rules that observers of corporate governance around the world (e.g., Paul Vishny 1994, Investor Responsibility Research Center 1994, Institutional Shareholder Services 1994, White 1993, American Bar Association 1989 and 1993) believe to be critical to the quality of shareholder and creditor legal rights. Moreover, we focus on variables that prima facie are interpretable as either pro-investor 
or pro-management, since this is the dimension along which we are trying to assess countries and legal families. There are obvious differences in rules between countries, such as for example tier structures of boards of directors, that we do not examine because we cannot ascertain which of these rules are more sympathetic to shareholders. Investor rights, as well as the other variables we use in this paper, are summarized in Table 1. We discuss individual variables in more detail in the sections where they are analyzed. The Appendix summarizes by country the data sources that were used to construct the data set ${ }^{3}$.

\section{Some Conceptual Issues}

The goal of our research, as we already mentioned, is to establish whether laws pertaining to investor protection differ across countries and whether these differences have consequences for corporate finance. This research design immediately poses some conceptual problems. To begin, some scholars, such as Easterbrook and Fischel (1991), are skeptical that legal rules are binding in most instances, since often firms can opt out of these rules in their corporate charters, which effectively serve as contracts between entrepreneurs and investors. Indeed, in many countries, firms can opt out of some of the rules we examine. As a practical matter, however, it may be costly for firms to opt out of standard legal rules since investors might have difficulty accepting non-standard contracts and, more importantly, judges might fail to understand or enforce them. Perhaps for this reason, standard legal rules appear to have some bite. Even more important, the

${ }^{3}$ The data collected for this paper come from multiple sources, ranging from publicly and commercially available data sets, to respective countries' laws and commentaries on these laws. We have been able to obtain nearly complete data for over 45 countries, and taken some care to assure their accuracy. The tables in this paper present all the data on legal rights and their enforcement that we use in the analysis. 
question of whether legal rules matter is fundamentally empirical: if opting out were cheap and simple, we would not find that legal rules matter for patterns of corporate ownership and finance

Even if we were to find that legal rules matter, it would be possible to argue that these rules endogenously adjust to economic reality, and hence the differences in rules and outcomes simply reflect the differences in some other, exogenous conditions across countries. Perhaps some countries chose to have only bank finance of firms for political reasons, and then adjusted their laws accordingly to protect banks and discourage shareholders. For some individual rules, this is surely the case. However, this is where our focus on the legal origin becomes crucial. Countries typically adopted their legal systems involuntarily (through conquest or colonization), and even when they chose a legal system freely, as in the case of former Spanish colonies, the crucial consideration was language and the broad political stance of the law rather than the treatment of investor protections. The legal family can therefore be treated as exogenous to a country's structure of corporate ownership and finance. If we find that legal rules differ substantially across legal families, and that so do financing and ownership patterns, we have a strong case that legal families, as expressed in the legal rules, actually affect outcomes.

Finally, this paper takes the rather standard point of view that investor protections contribute to external financing of firms, and hence to economic efficiency. This need not necessarily be the case. A country might develop and grow with limited legal protections of outside investors, and with only internal and state finance of firms. Our paper does not address this theoretical issue; it rather relies on the existing research (surveyed, e.g., by Shleifer and Vishny 1996) to presume that investor protections are good for economic efficiency. 
3. Shareholder rights.

We begin by considering shareholder rights from company laws. Because shareholders exercise their power by voting for directors, experts focus on voting procedures in evaluating shareholder rights. These include: voting rights attached to shares, rights that support the voting mechanism against interference by the insiders, and what we call remedial rights. To begin, investors may be better protected when dividend rights are tightly linked to voting rights, i.e. companies in a country are subject to one-share-one-vote rules (Grossman and Hart 1988, Harris and Raviv 1988) ${ }^{4}$. The idea is that, when votes are tied to dividends, insiders cannot appropriate cash flows to themselves by controlling only a small share of the company's cash flows but still maintaining voting control. There are many ways out of the one-share-one-vote principle that laws in different countries accommodate. Companies can issue non-voting shares, low and highvoting shares, founders' shares with extremely high voting rights, or shares whose votes increase when they are held longer, as in France. Companies can also restrict the total number of votes that any given shareholder can exercise at a shareholders' meeting, regardless of how many votes he controls. We say that a country has one-share one-vote if none of these practices is allowed by law. In our sample, only 11 countries impose genuine one-share one-vote rules.

The next five rights are much more straightforward, and essentially describe how easy it is for shareholders to exercise their voting rights. Because these rights measure how strongly the legal system favors shareholders (against managers) in the voting process, we refer to them as anti-director rights. First, in some countries, shareholders must show up in person, or send an

${ }^{4}$ One of the European Community directives recommends the adoption of one-share-onevote rules throughout the Community. It does not appear that this directive is being incorporated into national laws too rapidly. 
authorized representative, to a shareholders' meeting to be able to vote. In other countries, in contrast, they can vote by mail, which makes it easier for them to cast their votes. In Japan, for example, about 80 percent of companies hold their annual meeting on the same week, and voting by mail is not allowed, which makes it difficult for shareholders to exercise their votes unless they go through a legal procedure of designating their proxies at the meetings.

Second, in some countries, law requires that shareholders deposit their shares with the company or a financial intermediary several days prior to a shareholder meeting. The shares are then kept in custody until a few days after the meeting. This practice prevents shareholders from selling their shares for several days around the time of the meeting, and keeps shareholders who do not bother to go through this exercise from voting.

Third, some countries allow cumulative voting for directors, which in principle gives more power for minority shareholders to put their representatives on boards of directors.

Fourth, some countries give minority shareholders legal mechanisms to be used against perceived oppression by directors. These mechanisms may include the right to sue directors (as in the American derivative suits) or the right to force the company to purchase shares of the shareholders who object to certain fundamental changes, such as mergers or asset sales.

Fifth, we look at the percentage of share capital needed to call an extraordinary shareholders' meeting. Presumably, the higher this percentage is, the harder it is for minority shareholders to organize a meeting to challenge or oust the management. This percentage varies around the world from 1 percent in some U.S. states to 33 percent of share capital in Mexico.

Finally, we combine these five anti-director rights into an aggregate anti-director rights measure described in Table 1. 
The last shareholder rights measure, which we treat a bit differently from others, is the right to a mandatory dividend. In some countries, companies are mandated by law to pay out a certain fraction of their declared earnings as dividends. Earnings of course can be misrepresented within the limits allowed by the accounting system, so this measure is not as tough as it looks, but at least it prevents declarations of high earnings, which might be needed to raise additional funds, without dividend payouts. The mandatory dividend right may be needed when other rights of shareholders are too weak to induce them to invest. We test this hypothesis in Section 5.

Table 2 presents the data on shareholder rights, where the values of all variables are listed by country, and countries are organized by legal origin. Columns in Table 2 generally correspond to particular legal provisions concerning shareholder rights, and the values in the tables are dummies indicating whether a country has the particular legal provision. Table 2 also presents equality of means tests for all the variables by origin.

An examination of world means of the variables in Tables 2 suggests that relatively few countries have legal rules favoring outside shareholders. Only 22 percent of the countries have one share one vote, only 16 percent allow cumulative voting, only 22 percent allow voting by mail, and only 53 percent protect oppressed minorities. One could argue that other -- private -mechanisms facilitate external equity finance, such as the managerial reputations (Gomes 1996). The point here is only that shareholder protections do not very often come from legal rules.

The other clear result in Table 2 is that, for many variables, the origin of laws matters. Although we present more formal statistical tests of this proposition later in this section, Table 2 shows that the means of shareholder rights variables are statistically significantly different between origins. Two variables where most origins are similar are one-share-one-vote, which is an 
uncommon restriction everywhere (and never happens in Scandinavia, which is therefore different), and cumulative voting, which is also uncommon everywhere (and never happens in Scandinavia, which is therefore different). With other variables, the differences in shareholder rights between legal origins are more substantial.

Specifically, two major facts emerge from Table 2. First, along a variety of dimensions, common law countries afford the best legal protections to shareholders. They most frequently (39\%) allow shareholders to vote by mail, they never block shares for shareholder meetings, they have the highest (92\%) incidence of laws protecting oppressed minorities, and they generally require relatively few shares (9\%) to call an extraordinary shareholder meeting. Not surprisingly, they also have the highest of all legal families aggregate anti-director rights score (3.39), including the only perfect 5 for the United States. Many of these differences between common law and civil law countries are statistically significant. In short, relative to the rest of the world, common law countries have a better package of laws protecting shareholders.

Second, along a broad range of dimensions, French civil law countries afford the worst legal protections to shareholders. Although they look average on one-share-one-vote $(24 \%)$ and cumulative voting (19\%), they have the lowest $(9 \%)$ incidence of allowing voting by mail, a high (43\%, though not as high as German civil law countries) incidence of blocking shares for shareholder meetings, a low (33\%, though not as low as Nordic countries) incidence of laws protecting oppressed minorities, and the highest (14\%) percentage of share capital needed to call an extraordinary shareholders' meeting. On the aggregate anti-director rights measure, French civil law countries look the worst (1.76). The differences between French civil law and common law are large and statistically significant, although other civil law families are not evidently more 
protective of shareholders than the French civil law countries are. Interestingly, even France itself, except for allowing proxies by mail, does not have good legal protections of shareholders. These results suggest that shareholders in the two most widely-spread legal regimes: common law and French civil law, operate in very different legal environments.

The German civil law countries are in general located between the two extremes, but closer to the French family. They have a relatively high frequency of one-share one-vote rules (because of East Asia) and require relatively few votes to call an extraordinary meeting, but they also typically block shares for shareholder meetings and rarely allow voting by mail. The average anti-director score for this family is 2.00 -- closer to the French family than to the common law family. Scandinavia presents a mixed picture, with an aggregate anti-director score of 2.50 . For example, only Denmark appears to have oppressed minority protections, and only Norway allows voting by mail.

The one remedial measure in Table 2, namely mandatory dividend, shows that mandatory dividends are used only in French civil law countries. This result is broadly consistent with the rest of our evidence, and suggests that mandatory dividends are indeed a remedial legal protection for shareholders who have relatively few other legal rights.

The final task of this section is to ask whether, in a statistical sense, once we consider all the legal rules at once, legal origin matters. In addressing this question, we must examine shareholder and creditor rights together, even though we discuss the results on creditor rights in the next section. We can also deal with another potential concern (addressed in more detail in section 7), namely that differences in legal origin just reflect differences in per capita income levels. Accordingly, we estimate a stacked regression using all the variables from Table 2 (other 
than the aggregate anti-director variable) plus the five creditor rights (described in Table 3 and the next section) as dependent variables, and origin dummies and levels of GNP per capita in each country as independent variables. Because within a country specific laws are correlated with each other, the appropriate estimation method is Seemingly Unrelated Regression. We can then perform F-tests of the hypothesis that origin matters for shareholder rights. The results of the regressions are presented in Table 4, and the F-tests in Table 5.

The results in Table 4 confirm the findings of Table 2 that civil law, and especially French civil law, countries have inferior protections of shareholders to those of the common law countries. Controlling for per capita income does not change this result (we return to per capita income in section 7). The tests in Panel A of Table 5 furthermore show that, even controlling for per capita income levels, legal origin matters for laws protecting shareholders. With reasonable confidence, we can reject the hypothesis that any given origin has the same laws as the rest of the world. Moreover, the table shows that the two origins that are most different from the others are French civil law and common law. We can also reject the hypotheses that the laws in the German family are the same as those in either the French or the common law families.

These formal tests are consistent with the principal finding of this section, namely that common law countries have the relatively better protections of shareholders, and the French civil law countries have the worst ones ${ }^{5}$. A minority shareholder in Australia or South Africa can vote

\footnotetext{
${ }^{5}$ Some European legal scholars have objected to this conclusion on the grounds that our selection of variables was biased toward finding common law countries more protective of investors. One variable that these scholars objected to our not using is the mandatory preemptive right to buy new shares given by many European countries to the existing shareholders.

Originally, this right did not appear to us to be critical, which is why we did not include it. After this criticism, we have analyzed the data on this right, although we did not include the results in the basic tables since this right was selected to favor civil law countries. As it happens, 56
} 
by mail, can trade his shares during a shareholders' meeting, is protected from certain expropriations by directors, and needs to have only $5 \%$ of share capital to call an extraordinary meeting. A minority shareholder in Italy or Belgium, in contrast, cannot vote by mail, has his shares blocked during the shareholder meeting, is not protected from expropriation by directors and needs to have $20 \%$ of share capital to call for an extraordinary meeting. The differences between legal origins come out loud and clear from this analysis of shareholder rights.

\section{Creditor Rights.}

Conceptually, creditor rights are more complex than shareholder rights. The reason is that creditors exercise their power in several ways. Perhaps the most basic creditor right is the right to repossess -- and then liquidate or keep -- collateral when a loan is in default (see Hart 1995). For collateralized loans, the power of creditors against borrowers depends largely on the ease of repossessing collateral. In some countries, law makes it difficult for the lenders to repossess collateral, in part because such repossession leads to liquidation of firms that is viewed as socially undesirable. In these countries, lenders may still have some powers against borrowers, namely their votes in the decisions for how to reorganize the company and pay off the creditors. The creditor rights that experts consider to be essential for debt finance are the rights to repossess collateral and to have a say in reorganization (see Paul Vishny 1994, Aghion, Hart, and Moore

percent of common law countries have this rule, compared to 76 percent of French civil law countries $(t=1.36), 50$ percent of German civil law countries $(t=.23$ in the comparison to common law), and 100 percent of Scandinavian countries $(t=-3.69$ in the comparison to common law). Thus the principal comparison of common law to French, and even German, civil law families is not materially affected by the inclusion of this variable. We have also checked all our further results and none are affected by the inclusion of this measure of preemptive shareholder rights. 
1992, Baird 1995, White 1993).

We use five creditor rights variables in this analysis. First, in some countries, the reorganization procedure imposes an automatic stay on the assets, thereby preventing secured creditors from getting possession of loan collateral. This rule obviously protects managers and unsecured creditors against secured creditors and prevents automatic liquidation. In Greece, for example, secured creditors have the right for foreclose on their property when their claim matures and not when the borrower defaults (Guide to Insolvency in Europe 1989, p. 112). In other countries, in contrast, secured creditors can pull collateral from firms being reorganized without waiting for completion of reorganization.

Second, some countries do not assure the secured creditors the right to collateral in reorganization. In these, admittedly rare, countries, secured creditors are in line behind the Government and workers, who have absolute priority over them. To use Mexico as an example, various social constituencies need to be repaid before the secured creditors, often leaving the latter with no assets to back up their claims.

Third, with respect to reorganization, management in some countries can seek protection from creditors unilaterally by filing for reorganization, without creditor consent. Such protection is called Chapter 11 in the United States, and gives management a great deal of power against creditors, since at best creditors can get their money or collateral only with a delay. In other countries, in contrast, creditor consent is needed to file for reorganization, and hence managers cannot so easily escape creditor demands.

Finally, in some countries, management stays pending the resolution of the reorganization procedure, whereas in other countries, such as Malaysia, management is replaced by a party 
appointed by the court or the creditors. This threat of dismissal may enhance creditors' power.

As with shareholder rights, we use one remedial creditor rights measure, namely the existence of a legal reserve requirement. This requirement forces firms to maintain a certain level of capital to avoid automatic liquidation. It protects creditors when they have few other powers in that it forces an automatic liquidation before all the capital is stolen or wasted by the insiders.

The results on creditor rights are presented in Table 3, which is organized in the same way as Table 2. In general, the protections of creditor rights analyzed here are more common than the protections of shareholder rights. Over half the countries restrict the managers' right to seek protection from creditors unilaterally, 85 percent pay secured creditors first, nearly half do not have automatic stay on assets, and 43 percent remove management in reorganization proceedings. As in Table 2, we see that, for many creditor rights, the legal origin matters (again we defer the Ftests to the end of this section). Moreover, the ranking of origins by the extent of investor protection is similar for creditors to what it is for shareholders.

Common law countries offer creditors better legal protections against managers. They most frequently ( $71 \%$, roughly tied with Scandinavia) preclude managers from unilaterally seeking court protection from creditors; they have the lowest (29\%) incidence of allowing automatic stay on assets; with one exception, they guarantee that secured creditors are paid first (as do German civil law and Scandinavian families); and they have far and away the lowest (24\%) incidence of managers staying on the job in reorganization proceedings. The United States is actually one of the most anti-creditor common law countries: it allows unimpeded petition for reorganization, permits automatic stay on assets, and lets managers keep their jobs in reorganization.

Creditor rights results also resemble those for shareholder rights in that the French civil 
law countries offer creditors the weakest protections. Few of them (42\% -- still more than German civil law countries) place restrictions on managers seeking court protection from creditors, many ( $74 \%$, tied with Scandinavia) allow the automatic stay on assets, relatively few $(68 \%)$ assure that secured creditors are paid first, and the vast majority $(74 \%$, though not as many as in Scandinavia) allow managers to stay on the job in reorganization proceedings.

On some measures, countries in the German civil law family are strongly pro-creditor. For instance, relatively few (33\%) of them allow automatic stay and secured creditors in all of them are paid first. On the other hand, relatively few of these countries (33\%) prevent managers from getting protection from creditors unilaterally, and most (67\%) allow managers to stay in reorganization. One view of this evidence is that the German civil law countries are very responsive to secured creditors by not allowing automatic stay and by letting them pull collateral. As a consequence of making liquidation easy, these countries rely less on reorganization of defaulting firms, and hence being soft on such firms by letting managers stay may not be a big problem. Scandinavia, as before, has some pro-management and some pro-creditor laws. The main differences, as with shareholders, are between common law and French civil law countries.

The evidence on the one remedial pro-creditor legal rule in the sample, namely the legal reserve requirement, is consistent with the rest of our findings. Specifically, these requirements almost never exist in common law countries, where other investor protections presumably suffice. On the other hand, these requirements are more common in all civil law countries. Since legal reserve requirements are likely to protect unsecured creditors in particular, it is not surprising that they are relatively common in the German civil law countries, which tend to be as bad as the French civil law countries in treating unsecured creditors. Remedial rights, then, are used when 
other investor powers are insufficient to enable them to earn returns on their investments.

From this analysis, it appears that the ranking of origins is roughly the same for creditor and shareholder protections. Some legal families -- relatively speaking -- protect all investors, and others protect none. It does not appear that some legal families protect shareholders and others protect creditors. We can ask this question more formally by looking at the correlations, across countries, between shareholder and creditor rights measures. This is done in Table 6 . The results do not support the hypothesis that countries protect either shareholders or creditors, and if anything, suggest the reverse. For example, the correlation of oppressed minority rights is .08 with restrictions on managers unilaterally seeking protection from creditors, -.23 with having an automatic stay on assets, .18 with having secured creditors first in line, and -.33 with managers staying in reorganization. In short, we have no systematic evidence that legal rules discriminate between investor types, except that German civil law countries are partial to secured creditors.

Next, we return to Tables 4 and 5 and formally ask the question whether origin matters for creditor rights. Table 4 confirms the results in Table 3 that, for several creditor rights, origin matters, even after controlling for per capita income. The formal tests show even more strongly than for shareholder rights that origin matters. Every family of laws (other than Nordic) is statistically different from the rest of the world, and common law countries are different from civil law countries. We can reject the hypothesis that French civil law countries have the same creditor rights as German civil law countries. The last panel of Table 5 pulls shareholder and creditor rights together and confirms the result that laws in different families are different. With all the data pulled together, we actually reject the hypothesis that any two families of laws are the same ${ }^{6}$. 
To summarize, our results on shareholder and creditor rights paint a very straightforward picture. Laws differ a great deal across countries, and in particular they differ because they come from different legal families. Relatively speaking, common law countries protect investors the most, and French civil law countries protect them the least. German civil law countries are in the middle, though probably closer to the civil law group. The one exception is the strong protections that German civil law countries afford secured creditors. Scandinavian countries have some strong and some weak protections of investors. The statistical evidence indicates that these results are not a consequence of different income levels of countries with different laws.

These results raise some questions. If poor investor protections are actually costly to companies in terms of their ability to raise funds, then do countries compensate for these shortcomings in other ways? We have already shown that French civil law countries have a higher incidence of remedial or bright line legal protections, such as mandatory dividends and legal reserves. But there may be other strategies to compensate, at least in part, for investorunfriendly laws. One of them -- examined in the next section -- is strict and effective enforcement of the laws that do exist. The other -- examined in section 6 -- is concentrated ownership.

Although we try to examine all the components of the legal system, the superiority of common law, and inferiority of the French civil law, in protecting investors is a key finding of our paper.

\section{Enforcement.}

${ }^{6}$ We have also conducted these tests controlling for geography, dividing the world into Australia, Europe, Africa, Asia, and America. In the combined comparison of shareholder and creditor rights, only the difference between Scandinavia and the rest of the world loses significance; all the remaining differences remain highly statistically significant. 
Legal rules are only one element of investor protection; the enforcement of these rules may be equally, or even more, important. A strong system of legal enforcement could even substitute for weak rules, since active and well-functioning courts can step in and rescue investors abused by the management. To address these issues, in addition to measures of investors' legal rights, this paper examines proxies for the quality of enforcement of these rights, namely estimates of "law and order" in different countries compiled by credit risk agencies. These measures are collected by private firms for the use of foreign investors interested in doing business in the respective countries. We use five of these measures: efficiency of the judicial system, rule of law, comuption, risk of expropriation -- meaning outright confiscation or forced nationalization -- by the government, and likelihood of contract repudiation by the government. The first two of these measures obviously pertain to law enforcement proper; the last three deal more generally with the government's stance toward business. Some of these measures have been previously shown to affect national growth rates (Keefer and Knack 1995).

In addition to these rule of law variables, this study uses an estimate of the quality of a country's accounting standards. Accounting plays a potentially critical role in corporate governance. For investors to know anything about the companies they invest in, some basic accounting standards are needed to render company disclosures interpretable. Even more important, contracts between managers and investors typically rely on some measures of firms' income or assets being verifiable in court. If a bond covenant stipulates immediate repayment when income falls below a certain level, this level of income must be verifiable for the bond contract to be even in principle enforceable in court. Accounting standards might then be necessary for financial contracting, especially if investor rights are weak (Hay, Shleifer and Vishny 
1996). The measure of accounting standards we use, like the rule of law measures, is a privately constructed index based on examination of company reports from different countries.

Unfortunately, it is available for only 44 countries, 41 of which are in our sample ${ }^{7}$.

Table 7 examines country scores on the various rule of law measures, as well as on their accounting standards. As before, it arranges countries by legal origin, and presents tests of equality of means between families. The table suggests that quality of law enforcement differs across legal families. However, the picture is different from that for the legal rules.

In law enforcement, Scandinavian countries are clearly on top, with German civil law countries close behind. These families have the highest scores of any group on the efficiency of the judicial system, the rule of law, corruption, risk of expropriation, and risk of contract repudiation by the government. On all the measures of rule of law, common law countries are behind the leaders, but ahead of the French civil law countries. The statistical significance of these results varies from variable to variable. The French civil law countries are behind all others on the quality of law enforcement just as they were on the quality of legal protections of investors.

With quality of accounting, the results are somewhat different. Scandinavia still comes out on top, though common law countries are second, (statistically significantly) ahead of the German civil law countries. As with all the other measures, the French family has the weakest quality of accounting. Thus, although with these enforcement variables common law and German civil law countries are closer together than they were with the legal rights variables, the French

${ }^{7}$ The measure of accounting standards we use was published in 1991. At around the same time, European countries began to harmonize their accounting standards under the pressure from the EC. Over time, accounting standards may converge in Europe. However, for the purposes of our analysis of country differences, and of determinants of ownership, historical differences in the quality of standards are obviously more important than the future convergence. 
civil law countries retain their last place.

These results do not support the conclusion that the quality of law enforcement compensates for the quality of laws. An investor in a French civil law country is poorly protected by both the laws and the system that enforces them. The converse is true for an investor in a common law country, on average.

An inspection Table 7 suggests that, for the enforcement measures, the level of per capita income may have a more important confounding effect than it did for the laws themselves. In Table 8, we investigate whether quality of enforcement is different in different legal families through regression analysis across countries. In the regressions, we control for each country's level of per capita income. The omitted dummy in the regressions is for common law countries.

By every single measure, richer countries have higher quality of law enforcement. Nonetheless, even controlling for per capita income, the legal family matters for the quality of enforcement and the accounting standards. A great deal of the cross-sectional variance in these rule of law scores is explained by per capita income and the legal origin. In some cases, these variables together explain around 80 percent of the cross-sectional variation in rule of law scores, with the lion's share of the explanatory power coming from per capita income.

Once income is controlled for, the conclusions change somewhat. French civil law countries still score lower on every single measure, and statistically significantly lower for almost all measures, than the common law countries do. However, once per capita income is controlled for, German civil law countries tend to score lower than the common law countries on all measures other than repudiation of contracts by government, although the effect is significant only for the efficiency of the judiciary and the accounting standards. Scandinavian countries are 
similar to common law countries in rule of law measures. The regression results thus continue to show that legal families with investor-friendlier laws are also the ones with stronger enforcement of laws. Poor enforcement and accounting standards aggravate, rather than cure, the difficulties faced by investors in the French civil law countries.

As a final step in this section, we examine more closely the two remedial legal rules that protect investors -- mandatory dividend and legal reserve requirements. We can now examine the hypothesis that these rules are an adaptation to weak laws protecting investors as well as to poor enforcement of laws. In Table 9, we examine how per capita income, efficiency of the judiciary, quality of the accounting standards, and legal origin determine the likelihood that a country resorts to these remedial legal rules. The three regressions we present use mandatory dividend, legal reserve, and an aggregate indicator (remedy dummy) equal to one if a country has either a mandatory dividend or a legal reserve requirement.

The results in Table 9 point to some substitution between different investor protection measures. The results are weak for mandatory dividends in that no variable enters the regression with statistical significance. The results are stronger for the legal reserves requirement, and very strong (with an adjusted R-squared of .77 ) for the combined dummy as a dependent variable.

The results on per capita income are mixed, except we have an interesting finding that having at least one of the remedial rules is more likely in a richer country. The law cnforcement variables enter with the expected signs in all regressions, but are most significant in the "any remedy" regression. Countries with poor efficiency of the judicial system or with poor accounting standards are more likely to adopt remedial legal measures, consistent with the substitution hypothesis. This result also supports our earlier conjecture that the implementation of some of 
the more elaborate legal rules, such as protections of oppressed minorities, might require sophisticated accounting standards, so that, in the absence of such standards, a legal system may need to resort to remedial measures. Finally, the results show quite clearly that, relative to common law countries, remedial rules are more likely to exist in civil law countries. Consistent with our earlier findings, these results point to the need for remedial laws in countries where other laws protect investors the least. In sum, the results in Table 9 are consistent with the hypothesis that remedial laws are an adaptation to poor laws protecting investors and to poor enforcement of laws, including poor accounting standards.

\section{Ownership.}

In this section, we explore the hypothesis that companies in countries with poor protections of investors adapt through concentrated ownership of their shares. The idea is that, when investors have relatively few legal rights, then managers can be induced to return the money to these investors is if one, or a very small number, of investors own the majority of shares. Moreover, it is unattractive to be a small investor in such a company, since one is bound to be expropriated by either the managers or the large investors, including the banks, themselves. In contrast, when legal protections are stronger, it is possible for ownership to be more dispersed and for small investors to expect a return on their capital. It may still be desirable to have some ownership concentration, since large shareholders might monitor managers and thus increase the value of the firm (Shleifer and Vishny 1986). With stronger legal protections, however, small investors can expect to benefit from these efforts by large shareholders, and hence some ownership dispersion is possible. This tradeoff between legal protections and ownership 
concentration, stressed by Shleifer and Vishny (1996), is tested below.

To this end, we have assembled a data base of up to 10 largest by market capitalization non-financial (i.e., no banks) domestic (i.e., no foreign multinationals) publicly traded (i.e., not $100 \%$ privately or government held) companies in each country in our sample. In countries where the largest publicly traded companies had some government ownership, we tried in addition to find at least 10 companies with no government ownership. This changed the list substantially in a few countries (Brazil, Austria, Egypt). For some countries, including Egypt, India, Nigeria, Philippines, and Zimbabwe, we could not find 10 such companies and settled for at least five.

For each company, we collected data on its three largest shareholders, and computed the combined (cash flow) ownership stake of these three shareholders. We did not correct for the possibility that some of the large shareholders are affiliated with each other, or that the company itself owns the shares of its shareholders (both of these corrections would raise effective concentration). Nor could we distinguish empirically between large shareholders who are the management, affiliated with the management, or separate from the management. It is not clear that a conceptual line between management and, say, a 40 percent shareholder can be drawn.

Subject to these caveats, it is possible to construct measures of ownership concentration. For each country, we took the average and the median ownership stake of the three largest shareholders among its 10 largest publicly traded companies. This measure resembles measures of ownership concentration used for American companies by Demsetz and Lehn (1985), Shleifer and Vishny (1986), and Morck, Shleifer and Vishny (1988), although concentration of ownership in the world turns out to be very different from that in the United States.

Table 10 begins by presenting our ownership data, as usual by legal origin. Recall that we 
are getting the concentration variable from up to 10 most valuable publicly traded companies in each country, and have a separate variable for ownership concentration using all owners, using private owners only, and using private owners in the largest companies that have no government ownership. As in turns out, government ownership of shares in publicly traded companies is not that common, and hence the results are not particularly affected by the corrections for government ownership. We therefore discuss the results for the companies with no government ownership. Note finally that we have been able to obtain ownership data for 45 out of our 49 countries.

Table 10 contains perhaps the single most surprising finding of our paper. In the world as a whole, even if we focus on the largest publicly traded companies, the average ownership of the three largest shareholders is 46 percent, with the median of 45 percent. Dispersed ownership in large public companies is simply a myth. Even in the United States, the average for the 10 most valuable companies is 20 percent (which is partly explained by the fact that Microsoft, Walmart, Coca-Cola, and Intel are on the list and all have significant ownership concentration), and the median is 12 percent. The average concentration measure we use is under 30 percent only for the United States, Australia, United Kingdom, Taiwan, Japan, Korea and Sweden. Presumably, if we looked at smaller companies, the numbers we would get for ownership concentration would be even larger. The finance textbook model of management faced by multitudes of dispersed shareholders is an exception and not the rule.

Table 10 also shows that ownership concentration varies by legal origin. By far the highest concentration of ownership is found in the French civil law countries, with the average ownership by the three largest shareholders of a whopping 54 percent for the 10 largest nongovernment firms. The lowest concentration is in the German civil law countries, and is equal to 
34 percent. Interestingly, this low concentration comes from East Asia rather than from Germany, Austria, or Switzerland. Scandinavian countries are also relatively low, with 37 percent concentration. Finally common law countries are in the middle, with 43 percent average ownership concentration. The differences between the French civil law countries and other legal families are statistically significant, although other differences are not. In sum, these data indicate that the French civil law countries have unusually high ownership concentration, just like they have unusually poor legal protections of investors and enforcement of laws. These results are at least suggestive that concentration of ownership is a response to poor legal protection.

In Table 11, we examine empirically the determinants of ownership concentration, in two steps. First, we regress ownership concentration on legal origin dummies and several control variables, to see whether origin matters. The controls we use are: (the logarithm of) GNP per capita on the theory that richer countries may have different ownership patterns; (the logarithm of) total GNP on the theory that larger economies have larger firms which might therefore have lower ownership concentration; and the Gini coefficient for a country's income on the theory -suggested to us by several readers -- that more unequal societies have higher ownership concentration. Second, we add to the first regression several measures of legal protections, including accounting standards, enforcement quality, shareholder rights, creditor rights, and the remedial rights. Given the large number of variables collected for this paper, we cannot estimate all the possible regressions, and we need to make some choices. We pick "rule of law" as our measure of quality of enforcement, and several creditor and shareholder rights from Tables 2 and 3. The results we present are representative of other specifications.

Table 11 presents the results. The first regression, with all 45 observations, has an 
adjusted R-squared of 49 percent, which is high for a cross-country specification. It shows that larger countries have lower ownership concentration, and more unequal countries have higher ownership concentration, consistent with the conjectured effects of these controls. In addition, the basic regression, consistent with the results in Table 10, shows a higher concentration of ownership in the French civil law countries.

The second regression in Table 11 addresses this question. The regression has only 39 observations because, as before, data on accounting standards are incomplete. Still, an adjusted R-squared rises to 58 percent. The coefficients on controls remain significant, and in fact the coefficient on per capita income becomes significant and positive. The coefficient on the French origin dummy turns negative but completely insignficiant, which suggests that our measures of investor protections actually capture the limitations of the French civil law system. Several of the measures of investor protection actually help determine ownership concentration. Countries with better accounting standards and rule of law have a statistically significantly lower concentration of ownership. A 20 point increase in the accounting score (the distance between the common law and French civil law averages) reduces average ownership concentration by 9 percentage points, whereas a .4 point increase in the rule of law score (again, the distance between the common law and French civil law averages) reduces average ownership by almost 1 percentage point.

Furthermore, countries with better shareholders' antidirector rights, as measured by our aggregate variable, also have a statistically significantly lower concentration of ownership. A 1.6 points increase in the anti-director rights score (again, the distance between common law and French civil law averages) reduces ownership concentration by 8 percentage points. In contrast, the one-share-one-vote variable is not significant. 
The measures of creditor rights are not significant. Theoretically, the effect of creditor rights on ownership concentration is ambiguous. One could argue that when creditor rights are good, bank borrowing becomes pervasive, and small shareholders can free ride on the monitoring by banks, making dispersed ownership possible. On the other hand, one could also argue that, when creditor rights are good, bank borrowing is easier, and therefore firms will finance their investment through debt rather than equity, leading to higher ownership concentration in equilibrium. The lack of empirical association between creditor rights and ownership concentration is consistent with this theoretical ambiguity.

A word of caution is in order in interpreting these results. Some of our independent variables, but particularly accounting standards, might be endogenous. Countries that for some reason have heavily concentrated ownership and small stock markets might have little use for good accounting standards, and so fail to develop them. The causality in this case would be from ownership concentration to accounting standards, rather than the other way around. Since we have no instruments that we believe determine accounting but not ownership concentration, we cannot reject this hypothesis, although we do not find it as plausible as ours. Of course, the legal rules that we use as our independent variables, and the legal origins that shape these rules, are more likely to be exogenous to ownership concentration.

In sum, the message of Table 11 is that the quality of legal protection of shareholders, as well as the extent of protection of the voting process against manipulation by directors, are significant determinants of ownership concentration. Moreover, between them, these variables account for the higher concentration of ownership in the French civil law countries. The results support the idea that heavily concentrated ownership results from, and perhaps substitutes for, 
poor protection of investors in a corporate governance system. The evidence indicates that poor laws actually make a difference and may have costs. One of these costs of heavily concentrated ownership in large firms is that their core investors are not diversified. The other cost is that these firms probably face difficulty raising equity finance, since minority investors fear expropriation by managers and concentrated owners.

\section{Per capita income.}

In the previous sections, we have presented results in which we controlled for per capita income in assessing the differences between the legal families. We have established that per capita income is not the whole story. In this section, we focus on per capita income itself as a determinant of a country's law and its enforcement. Do poor countries have systematically worse legal protections than rich countries do? If this were the case, then the possibility would exist that poor countries are stuck in a bad equilibrium of inadequate legal protection and scarce external finance, which would stunt growth and therefore keep them poor and with inadequate legal protection. On the other hand, if per capita income is not a critical determinant of effective legal protection, then even if poor laws slow down financing and investment, countries can still grow out of the trap. In this section, we attempt to shed some light on these issues.

In Table 12, we sort countries by per capita income into the bottom quartile, middle 50 percent, and the top quartile. We then compare the means of some of our variables across per capita income groups. Shareholder rights do not systematically depend on the level of per capita income. Table 12 shows this for the aggregate quality of shareholder rights variable, but the result holds for individual rights as well. The unimportance of per capita income as a determinant 
of shareholder rights is apparent from the regressions in Table 4, which control for legal origin.

Table 12 also suggests that some of the creditor rights, such as the restriction on managers' right to unilaterally seek protection from creditors, no automatic stay on assets, and the replacement of managers in bankruptcy proceedings, actually get weaker in richer countries Some of these results, in weaker form, appear in the regressions in Table 4 , which control for legal origin. Interestingly, the one measure that rises most clearly with income is management staying in reorganization. It is possible that the relative anti-management stance of poor countries' bankruptcy laws is dictated by efficiency: unless creditors get their hands on the assets fast, these assets are likely to disappear. It is also possible that, in richer countries, management lobbying has succeeded in emasculating creditor rights. The aggressive pro-management stance of the U.S bankruptcy law is consistent with both of these interpretations. In any event, there is no evidence that poor countries have weaker creditor rights.

As we already reported in Table 8, however, the efficiency of the judicial system and rule of law both increase substantially with the level of income. In fact, per capita GNP alone explains over half of the variation in enforcement measures. The quality of the accounting standards also rises sharply with per capita income, although we have very few observations for the poorer countries. The picture is thus very different for law enforcement than it is for legal rules.

In summary, the data provide no evidence of a legal trap: systematically weaker laws protecting investors in poorer countries. There is no systematic correlation between income and shareholder rights, and, if anything, some creditor rights are weaker in richer countries. What this means is that some countries -- such as Italy and France -- have managed to get rich despite having few laws that protect investors. On the other hand, richer countries have a clearly higher 
quality of law enforcement. The failure of poor countries to consistently enforce basic investor protections may well help keep them poor.

\section{Conclusions.}

In this paper, we have examined laws governing investor protection, the quality of enforcement of these laws, and ownership concentration in 49 countries around the world. The analysis suggests three broad conclusions.

First, laws differ markedly around the world, though in most places they tend to give investors a rather limited bundle of rights. In particular, countries whose legal rules originate in the common law tradition tend to protect investors considerably better than do the countries whose laws originate in the civil law, and especially the French civil law, tradition. The German civil law and the Scandinavian countries take an intermediate stance toward investor protections. There is no clear evidence that different countries favor different types of investors; the evidence rather points to a relatively stronger stance favoring all investors in common law countries. This evidence confirms our basic hypothesis that being a shareholder, or a creditor, in different legal jurisdictions entitles an investor to very different bundles of rights. These rights are determined by laws; they are not inherent in securities themselves.

Second, law enforcement differs a great deal around the world. German civil law and Scandinavian countries have the best quality of law enforcement, although this reflects to some extent their higher average income levels. Law enforcement is strong in common law countries as well, whereas it is the weakest in the French civil law countries. These rankings also hold for one critical input into law enforcement in the area of investor protections: the accounting standards. 
These standards are ranked the lowest in the French civil law countries, where an investor is generally protected neither by the laws nor by high quality law enforcement. The quality of law enforcement, unlike the legal rights themselves, improves sharply with the level of income.

Third, we have examined the concentration of ownership in publicly traded companies around the world, and investigated the hypothesis that highly concentrated ownership is an adaptive response to poọr investor protection in a corporate governance system. To begin, we have shown that ownership concentration is extremely high around the world, consistent with our evidence that laws, on average, are not terribly protective of investors. In an average country, close to half the equity in a publicly traded company is owned by the three largest shareholders. Good accounting standards, rule of law, and shareholder protection measures are highly negatively correlated with the concentration of ownership. These results suggest that inadequate protection of investors may be costly. Specifically, if small investors are not protected, companies would not be able to raise capital from them, and entrepreneurs would not be able to diversify their holdings. High ownership concentration, then, may be a symptom of a poorly functioning capital market.

These findings leave us with a puzzle. The most widely spread legal family, that originating in the French civil law, appears to have the worst efficiency properties from the perspective of corporate governance. While this system was often not adopted voluntarily, it was chosen by at least some governments, and has survived for decades around the world. How can it be so popular if, as our results suggest, it is so bad? One possible answer is that, when countries adopt a legal system, their leaders are more focused on its revolutionary spirit and on the more basic rights than those of investors. The legal reformers borrow the legal systems 
wholesale, without excessive focus on whether shareholders can vote by mail. Another possible answer -- related to arguments made in Easterbrook and Fischel (1991) -- is that the legal system does not matter very much, and that investors can generally contract around the limitations of the legal system. This answer, however, does not square with our evidence on ownership if one believes that extreme ownership concentration is costly. Even if one gives some credence to these arguments, the survival and spread of rules that appear so inferior remains puzzling. The ultimate question that needs to be answered to deal with this puzzle, of course, is whether countries with poor investor protections -- either laws or their enforcement -- actually do suffer. Do such countries, especially the French civil law countries, have smaller capital markets? Are their banking systems less developed? Are companies in these countries incapable of getting external finance? We defer this analysis to our follow-up paper, and for now leave the puzzle open. 
References.

Aghion, Philippe, Oliver Hart and John Moore (1992), "The Economics of Bankruptcy Reform," Journal of Law, Economics, and Organization 8, 523-546.

American Bar Association (1989 and 1993), Multinational Commercial Insolvency, Wisconsin: MG Publishing.

Andenas, Mads and Stephen Kenyon-Slade, eds. (1993), E.C. Financial Market Regulation and Company Law, London, U.K.: Sweet and Maxwell.

Baird, Douglas (1995), "The Hidden Virtues of Chapter 11: an Overview of the Law and Economics of Financially Distressed Firms," manuscript, Univ. of Chicago Law School.

Bebchuk, Lucian (1994), "Efficient and Inefficient Sales of Corporate Control," Quarterly Journal of Economics 109, 957-994.

Bebchuk, Lucian and Luigi Zingales (1995), "Corporate Ownership Structures: Private vs. Social Optimality," Working Paper, University of Chicago.

Berglof, Erik and Enrico Perotti (1994), "The Governance Structure of Japanese Financial Keretsu," Journal of Financial Economics 36, 259-284.

Berle, Adolf and Gardiner Means (1932), The Modern Corporation and Private Property, New York: Macmillan.

Boycko, Maxim, Andrei Shleifer and Robert W. Vishny (1993), Privatizing Russia, Brookings Papers on Economic Activity, 139-192.

David, Rene and John Brierley (1985), Major Legal Systems in the World Today, London: Stevens and Sons.

Deininger, Klaus and Lyn Squire (1996), "Measuring Income Inequality: a New Data-Base", 
mimeo, World Bank.

Demsetz, Harold and Kenneth Lehn (1985), "The Structure of Corporate Ownership: Causes and Consequences," Journal of Political Economy 93, 1155-77.

Easterbrook, Frank and Daniel Fischel (1991), The Economic Structure of Corporate Law, Cambridge: Harvard University Press.

Edwards, Jeremy and Klaus Fischer (1994), Banks, Finance and Investment in West Germany Since 1970, Cambridge, UK: Cambridge University Press.

Glendon, Mary Ann, Michael Gordon and Christopher Osakwe (1992), Comparative Legal Traditions in a Nutshell, St. Paul: West Publishing Company.

Gomes, Armando (1996), "The Dynamics of Stock Prices, Manager Ownership, and Private Benefits of Control," Manuscript, Harvard University.

Gorton, Gary and Frank Schmid (1996), "Universal Banking and the Performance of German Firms, " NBER Working Paper \#5453.

Gromb, Denis (1993), "Is One-share-One-vote Optimal?" Working Paper, LSE.

Grossman, Sanford and Oliver Hart (1988), "One-share-one-vote and the Market for Corporate Control," Journal of Financial Economics 20, 175-202.

Harris, Milton and Artur Raviv (1988), "Corporate Governance: Voting Rights and Majority Rules," Journal of Financial Economics 20, 203-236.

Hart, Oliver (1995), Firms, Contracts, and Financial Structure, London: Oxford University Press.

Hay, Jonathan, Andrei Shleifer, and Robert W. Vishny (1996), "Toward a Theory of Legal Reform," European Economic Review, forthcoming. 
Institutional Shareholder Services, Inc. (1994 and 1995), Proxy Voting Guidelines, several countries, ISS Global Proxy Services.

Investor Responsibility Research Center (1994, 1995), Proxy Voting Guide, Global Shareholder Service, Washington, DC: I.R.R.C.

Jensen, Michael and William Meckling (1976), "Theory of the Firm: Managerial Behavior, Agency Costs, and Ownership Structure," Journal of Financial Economics 3, 305-360. Kaplan, Steven and Bernadette Minton (1994), "Appointments of Outsiders to Japanese Boards: Determinants and Implications for Managers," Journal of Financial Economics 36, 225 257.

Keefer, Philip and Stephen Knack (1995), "Institutions and Economic Performance: CrossCountry Tests Using Alternative Institutional Measures," Economics and Politics. Levy, Haim (1982), "Economic Valuation of Voting Power of Common Stock," Journal of Finance 38, 79-93.

Merryman, John (1969), The Civil Law Tradition, Standord: University Pres.

Modigliani, Franco and Merton Miller (1958), "The Cost of Capital, Corporation Finance, and the Theory of Investment," American Economic Review 48, 261-297.

Morck, Randall, Andrei Shleifer and Robert W. Vishny, "Management Ownership and Market Valuation: an Empirical Analysis," Journal of Financial Economics 20, 293-315.

Pagano, Marco, F. Panetta, and Luigi Zingales (1995), "Why Do Companies Go Public: an Empirical Analysis," manuscript, University of Chicago.

Rajan, Raghuram and Luigi Zingales (1995), "What do we Know about Capital Structure: some Evidence from International Data," Journal of Finance 50, 1421-1460. 
Reynolds, Thomas and Arturo Flores (1989), Foreign Law: Current Sources of Basic Legislation in Jurisdictions of the World, Littleton, CO: Rothman and Co.

Roe, Mark (1994), Strong Managers, Weak Owners: the Political Roots of American Corporate Finance, Princeton, N.J.: Princeton University Press.

Rydquist, Kristian (1987), "Empirical Investigation of the Voting Premium," Northwestern University Working Paper \#35, Evanston, IL.

Shleifer, Andrei and Robert W. Vishny (1986), "Large Shareholders and Corporate Control," Journal of Political Economy 94, 461-488.

Shleifer, Andrei and Robert W. Vishny (1996), "A Survey of Corporate Governance," Journal of Finance, forthcoming.

Vishny, Paul (1994), Guide to International Commerce Law, New York: McGraw-Hill.

Watson, Alan (1974), Legal Transplants, Charlotsville, VA: University of Virginia Press.

Werlauff, Erik (1993), EC Company Law, Copenhagen: Jurist- og Okonomforbundets Forlag. White, Michelle (1993), "The Costs of Corporate Bankruptcy: the U.S. - European Comparison," manuscript, University of Michigan.

World Bank (1993), World Development Report, Washington, D.C.: Oxford University Press. World Bank (1993), Social Indicators of Development 1991-1992, Baltimore: Johns Hopkins University Press.

Zingales, Luigi (1994), "The Value of the Voting Right: a Study of the Milan Stock Exchange Experience," The Review of Financial Studies 7, 125-148.

Zingales, Luigi (1995), "What Determines the Value of Corporate Votes?" Quarterly Journal of Economics 110, 1075-1110. 
Zweigert, Konrad and Hein Kotz (1987), Introduction to Comparative Law, Oxford: Clarendon Press. 


\section{TABLE 1 : The Variables}

This table describes the variables collected for the 49 countries included in our study. The first column gives the name of the variable. The second column describes the variable and gives the range of possible values. The third column provides the sources from which the variable was collected.

\begin{tabular}{|c|c|c|}
\hline Variable & Description & Sources \\
\hline Origin & $\begin{array}{l}\text { Identifies the legal origin of the Company Law or Commercial Code of each country. } \\
\text { Equals } 1 \text { if the origin is English Common Law; } 2 \text { if the origin is the French Commercial } \\
\text { Code; and } 3 \text { if the origin is the German Commercial Code. }\end{array}$ & $\begin{array}{l}\text { Foreign Law Encyclopedia } \\
\text { Commercial Laws of the } \\
\text { World. }\end{array}$ \\
\hline One Share-One Vote & $\begin{array}{l}\text { Equals one if the Company Law or Commercial Code of the country requires that } \\
\text { ordinary shares carry one vote per share, and } 0 \text { otherwise. Equivalently, this variable } \\
\text { equals one when the law prohibits the existence of both multiple-voting and non-voting } \\
\text { ordinary shares and does not allow firms to set a maximum number of votes per } \\
\text { shareholder irrespective of the number of shares she owns, and } 0 \text { otherwise. }\end{array}$ & $\begin{array}{l}\text { Company Law or } \\
\text { Commercial Code }\end{array}$ \\
\hline Proxy by mail & $\begin{array}{l}\text { Equals one if the Company Law or Commercial Code allows shareholders to mail their } \\
\text { proxy vote, and } 0 \text { otherwise. }\end{array}$ & $\begin{array}{l}\text { Company Law or } \\
\text { Commercial Code }\end{array}$ \\
\hline $\begin{array}{l}\text { Shares blocked before } \\
\text { meeting }\end{array}$ & $\begin{array}{l}\text { Equals one if the Company Law or Commercial Code allows firms to require that } \\
\text { shareholders deposit their shares prior to a General Shareholders Meeting thus } \\
\text { preventing them from selling those shares for a number of days, and } 0 \text { otherwise. }\end{array}$ & $\begin{array}{l}\text { Company Law or } \\
\text { Commercial Code }\end{array}$ \\
\hline Cumulative voting & $\begin{array}{l}\text { Equals one if the Company Law or Commercial Code allows shareholders to cast all of } \\
\text { their votes for one candidate standing for election to the board of directors, and } 0 \\
\text { otherwise. }\end{array}$ & $\begin{array}{l}\text { Company Law or } \\
\text { Commercial Code }\end{array}$ \\
\hline $\begin{array}{l}\text { Oppressed minorities } \\
\text { mechanism }\end{array}$ & $\begin{array}{l}\text { Equals one if the Company Law or Commercial Code grants minority shareholders } \\
\text { either a judicial venue to challenge the management decisions or the right to step out of } \\
\text { the company by requiring the company to purchase their shares when they object to } \\
\text { certain fundamental changes, such as mergers, assets dispositions and changes in the } \\
\text { articles of incorporation. The variable equals } 0 \text { otherwise. }\end{array}$ & $\begin{array}{l}\text { Company Law or } \\
\text { Commercial Code }\end{array}$ \\
\hline $\begin{array}{l}\text { Percentage of Share } \\
\text { Capital to Call an } \\
\text { Extraordinary } \\
\text { Shareholders' Meeting }\end{array}$ & $\begin{array}{l}\text { It is the minimum percentage of ownership of share capital that entitles a shareholder to } \\
\text { call for an Extraordinary Shareholders' Meeting. It ranges from one to } 33 \text { percent. }\end{array}$ & $\begin{array}{l}\text { Company Law or } \\
\text { Commercial Code }\end{array}$ \\
\hline Antidirectors Rights & $\begin{array}{l}\text { An index aggregating the shareholder rights which we labeled as "anti-director rights." } \\
\text { The index is formed by adding } 1 \text { when: (1) the country allows shareholders to mail their } \\
\text { proxy vote; (2) shareholders are not required to deposit their shares prior to the General } \\
\text { Shareholders' Meeting; (3) cumulative voting is allowed; (4) an oppressed minorities } \\
\text { mechanism is in place; or (5) when the minimum percentage of share capital that entitles } \\
\text { a shareholder to call for an Extraordinary Shareholders' Meeting is less than or equal to } \\
10 \% \text { (the sample median). The index ranges from } 0 \text { to } 5 \text {. }\end{array}$ & $\begin{array}{l}\text { Company Law or } \\
\text { Commercial Code }\end{array}$ \\
\hline Mandatory Dividend & $\begin{array}{l}\text { Equals the percentage of net income that the Company Law or Commercial Code } \\
\text { requires firms to distribute as dividends among ordinary stockholders. It takes a value of } \\
0 \text { for countries without such restriction. }\end{array}$ & $\begin{array}{l}\text { Company Law or } \\
\text { Commercial Code }\end{array}$ \\
\hline $\begin{array}{l}\text { Restrictions on filing a } \\
\text { Reorganization petition }\end{array}$ & $\begin{array}{l}\text { Equals one if the reorganization procedure imposes restrictions, such as creditors' } \\
\text { consent, to file for reorganization. It equals } 0 \text { if there are no such restrictions. }\end{array}$ & $\begin{array}{l}\text { Bankruptcy and } \\
\text { Reorganization Laws }\end{array}$ \\
\hline $\begin{array}{l}\text { Automatic Stay on } \\
\text { Secured Assets }\end{array}$ & $\begin{array}{l}\text { Equals one if the reorganization procedure imposes an automatic stay on the assets of the } \\
\text { firm upon filing the reorganization petition. This restriction prevents secured creditors } \\
\text { to gain possession of their security. It equal } 0 \text { if such restriction does not exist in the } \\
\text { law. }\end{array}$ & $\begin{array}{l}\text { Bankruptcy and } \\
\text { Reorganization Laws }\end{array}$ \\
\hline Secured Creditors First & $\begin{array}{l}\text { Equals one if secured creditors are ranked first in the distribution of the proceeds that } \\
\text { result from the disposition of the assets of a bankrupt firm. Equals zero if non-secured } \\
\text { creditors, such as the Government and workers, are given absolute priority. }\end{array}$ & $\begin{array}{l}\text { Bankruptcy and } \\
\text { Reorganization Laws }\end{array}$ \\
\hline Management Stays & $\begin{array}{l}\text { Equals one if the debtor keeps the administration of its property pending the resolution } \\
\text { of the reorganization process, and zero otherwise. Equivantly, this variable equals zero } \\
\text { when an official appointed by the court, or by the creditors, is responsible for the } \\
\text { operation of the business during reorganization. }\end{array}$ & $\begin{array}{l}\text { Bankruptcy and } \\
\text { Reorganization Laws }\end{array}$ \\
\hline
\end{tabular}




\begin{tabular}{|c|c|c|}
\hline Variable & Description & Sources \\
\hline Legal Reserve & $\begin{array}{l}\text { It is the percentage of total share capital mandated by Corporate Law to avoid the } \\
\text { dissolution of an existing firm. It takes a value of zero for countries without such } \\
\text { restriction. }\end{array}$ & $\begin{array}{l}\text { Company Law or } \\
\text { Commercial Code }\end{array}$ \\
\hline $\begin{array}{l}\text { Efficiency of Judicial } \\
\text { System }\end{array}$ & $\begin{array}{l}\text { Assessment of the "efficiency and integrity of the legal environment as it affects } \\
\text { business, particularly foreign fims"produced by the country-risk rating agency Business } \\
\text { International Corpation. It "may be taken to represent investors' assessments of } \\
\text { conditions in the country in question". Average between 1980-1983. Scale from } 0 \text { to } \\
\text { 10, with lower scores lower efficiency levels. }\end{array}$ & $\begin{array}{l}\text { Business International } \\
\text { Corporation. }\end{array}$ \\
\hline Rule of Law & $\begin{array}{l}\text { Assessment of the law and order tradition in the country produced by the country-risk } \\
\text { rating agency International Country Risk (ICR). Average of the months of April and } \\
\text { October of the monthly index between } 1982 \text { and } 1995 \text {. Scale from } 0 \text { to } 10 \text {, with lower } \\
\text { scores for less tradition for law and order.(We changed the scale of this variable from its } \\
\text { original range going from } 0 \text { to } 6 \text { ). }\end{array}$ & $\begin{array}{l}\text { International Country Risk } \\
\text { Guide }\end{array}$ \\
\hline Corruption & $\begin{array}{l}\text { ICR's assessment of the corruption in government. Lower scores indicate "high } \\
\text { government officials are likely to demand special payments" and "illegal payments are } \\
\text { generally expected throughout lower levels of government" in the form of "bribes } \\
\text { connected with import and export licenses, exchange controls, tax assessment, policy } \\
\text { protection, or loans". Average of the months of April and October of the monthly index } \\
\text { between } 1982 \text { and } 1995 \text {. Scale from } 0 \text { to } 10 \text {, with lower scores for higher levels of } \\
\text { corruption. (We changed the scale of this variable from its original range from } 0 \text { to 6). }\end{array}$ & $\begin{array}{l}\text { International Country Risk } \\
\text { Guide }\end{array}$ \\
\hline Risk of Expropriation & $\begin{array}{l}\text { ICR's assessment of the risk of "outright confiscation" or "forced nationalization", } \\
\text { Average of the months of April and October of the monthly index between } 1982 \text { and } \\
\text { 1995. Scale from } 0 \text { to } 10 \text {, with lower scores for higher risks }\end{array}$ & $\begin{array}{l}\text { Intemational Country Risk } \\
\text { Guide }\end{array}$ \\
\hline $\begin{array}{l}\text { Repudiation of } \\
\text { Contracts by } \\
\text { Govemment }\end{array}$ & $\begin{array}{l}\text { ICR's assessment of the "risk of a modification in a contract taking the form of a } \\
\text { repudiation, postponement, or scaling down" due to "budget cutbacks, indigenization } \\
\text { pressure, a change in government, or a change in government economic and social } \\
\text { priorities." Average of the months of April and October of the monthly index between } \\
1982 \text { and } 1995 \text {. Scale from } 0 \text { to } 10 \text {, with lower scores for higher risks. }\end{array}$ & $\begin{array}{l}\text { International Country Risk } \\
\text { Guide }\end{array}$ \\
\hline Accounting Standards & $\begin{array}{l}\text { Index created by examining and rating companies' } 1990 \text { annual reports on their } \\
\text { inclusion or omission of } 90 \text { items. These items fall into } 7 \text { categories (general } \\
\text { information, income statements, balance sheets, funds flow statement, accounting } \\
\text { standards, stock data and special items). A minimum of } 3 \text { companies in each country } \\
\text { were studied. The companies represent a cross-section of various industry groups where } \\
\text { industrial companies numbered } 70 \% \text { while financial companies represented the } \\
\text { remaining } 30 \% \text {. }\end{array}$ & $\begin{array}{l}\text { International Accounting } \\
\text { and Auditing Trends, } \\
\text { Center for International } \\
\text { Financial Analysis \& } \\
\text { Research, Inc. }\end{array}$ \\
\hline $\begin{array}{l}\text { Ownership, } 10 \text { largest } \\
\text { fims }\end{array}$ & $\begin{array}{l}\text { The average percentage of common shares owned by the three largest shareholders in the } \\
\text { ten largest non-financial domestic firms in a given country. }\end{array}$ & $\begin{array}{l}\text { Moodys International, } \\
\text { CIFAR, EXTEL, } \\
\text { WorldScope, 20-Fs, Price- } \\
\text { Waterhouse and various } \\
\text { country sources. }\end{array}$ \\
\hline $\begin{array}{l}\text { Ownership, } 10 \text { largest } \\
\text { private firms }\end{array}$ & $\begin{array}{l}\text { The average percentage of common shares owned by the three largest shareholders in the } \\
\text { ten largest non-financial, privately-owned domestic firms in a given country. A firm is } \\
\text { considered privately owned if the State is not a known shareholder in it. }\end{array}$ & $\begin{array}{l}\text { Moodys International, } \\
\text { CIFAR, EXTEL, } \\
\text { WorldScope, 20-Fs, Price- } \\
\text { Waterhouse and various } \\
\text { country sources. }\end{array}$ \\
\hline $\begin{array}{l}\text { GNP and GNP per } \\
\text { capita }\end{array}$ & $\begin{array}{l}\text { Gross National Product and Gross National Product per capita expressed in constant } \\
\text { dollars of } 1994 \text {. }\end{array}$ & World Bank and IMF \\
\hline Gini Coefficient & $\begin{array}{l}\text { Gini Coefficient for income inequality in each country. When the } 1990 \text { coefficient is } \\
\text { not available, we use the most recent available. }\end{array}$ & $\begin{array}{l}\text { Deininger and Squire } \\
\text { (1996); World Bank }\end{array}$ \\
\hline
\end{tabular}


Table 2: Shareholder Rights around the World

This table classifies countries by legal origin and shows the shareholders' rights for each country. Exact definitions of each shareholders' right can be found in Table 1. Panel $B$ gives the test of means for the different legal origins.

\begin{tabular}{|c|c|c|c|c|c|c|c|c|}
\hline \multirow[b]{2}{*}{ COUNTRY } & \multicolumn{8}{|c|}{ Panel A SHAREHOLDERS' RIGHTS ( $\mathrm{l}=$ exists in the law) } \\
\hline & $\begin{array}{l}\text { One share - } \\
\text { One vote }\end{array}$ & $\begin{array}{c}\text { Proxy by mail } \\
\text { allowed }\end{array}$ & $\begin{array}{l}\text { Shares blocked } \\
\text { before Meeting }\end{array}$ & $\begin{array}{c}\text { Cumulative } \\
\text { Voting for dirs. }\end{array}$ & $\begin{array}{l}\text { Oppressed } \\
\text { Minority }\end{array}$ & $\begin{array}{l}\% \text { of Share Capital } \\
\text { to call an ESM }\end{array}$ & $\begin{array}{c}\text { Antidirector } \\
\text { Rights }\end{array}$ & $\begin{array}{c}\text { Mandatory } \\
\text { Dividend }\end{array}$ \\
\hline Australia & 0 & 1 & 0 & 0 & 1 & $0.05^{d}$ & 4 & 0.00 \\
\hline Canada & 0 & 1 & 0 & 0 & 1 & 0.10 & 4 & 0.00 \\
\hline Hong Kong & 1 & 1 & 0 & 0 & 1 & 0.05 & 4 & 0.00 \\
\hline India & 0 & 0 & 0 & 0 & 0 & 0.10 & 2 & 0.00 \\
\hline Ireland & 0 & 0 & 0 & 0 & 1 & 0.10 & 3 & 0.00 \\
\hline Israel & 0 & 0 & 0 & 0 & 1 & 0.10 & 3 & 0.00 \\
\hline Kenya & 0 & 0 & 0 & 0 & 1 & 0.10 & 3 & 0.00 \\
\hline Malaysia & 1 & 0 & 0 & 0 & 1 & 0.10 & 3 & 0.00 \\
\hline New Zealand & 0 & $\mathbf{I}$ & 0 & 0 & 1 & 0.10 & 4 & 0.00 \\
\hline Nigeria & 0 & 0 & 0 & 0 & 1 & 0.10 & 3 & 0.00 \\
\hline Pakistan & I & 0 & 0 & 1 & 1 & 0.10 & 4 & 0.00 \\
\hline Singapore & 1 & 0 & 0 & 0 & 1 & 0.10 & 3 & 0.00 \\
\hline South Africa & 0 & 1 & 0 & 0 & 1 & 0.05 & 4 & 0.00 \\
\hline Sri Lankn & 0 & 0 & 0 & 0 & 0 & 0.10 & 2 & 0.00 \\
\hline Thailand & 0 & 0 & 0 & 1 & 1 & $0.20^{\circ}$ & 3 & 0.00 \\
\hline UK & $\mathbf{0}$ & 1 & 0 & 0 & 1 & 0.10 & 4 & 0.00 \\
\hline US & $\mathbf{0}$ & 1 & 0 & 1 & 1 & 0.01 & 5 & 0.00 \\
\hline Zimbabwe & o: & 0 & 0 & 0 & 1 & 0.10 & 3 & 0.00 \\
\hline Ave Engllah origin & 0.22 & 0.39 & 0.00 & 0.17 & 0.92 & 0.09 & 3.39 & 0.00 \\
\hline Argentina & 0 & 1 & 1 & 1 & 1 & 0.05 & 4 & 0.00 \\
\hline Belgium & 0 & 0 & 1 & 0 & 0 & 0.20 & 0 & 0.00 \\
\hline Brazil & I & 0 & 0 & 0 & 1 & 0.05 & 3 & 0.50 \\
\hline Chile & I & 0 & 0 & 0 & 1 & 0.01 & 3 & 0.30 \\
\hline Colombia & 0 & 0 & 0 & 0 & 0 & 0.25 & I & 0.00 \\
\hline Ecuador & 0 & 0 & 0 & 0 & 1 & 0.25 & 2 & 0.50 \\
\hline Egypt & 0 & 0 & 0 & 0 & 0 & 0.10 & 2 & 0.00 \\
\hline France & 0 & 1 & 1 & 0 & 0 & 0.10 & 2 & 0.00 \\
\hline Greece & 1 & 0 & 1 & 0 & 0 & 0.05 & 1 & 0.35 \\
\hline Indonesia & 0 & 0 & 0 & 0 & 0 & 0.10 & 2 & 0.00 \\
\hline Italy & 0 & 0 & 1 & 0 & 0 & 0.20 & 0 & 0.00 \\
\hline Jordan & 0 & 0 & 0 & 0 & 0 & 0.15 & 1 & 0.00 \\
\hline Mexico & 0 & 0 & 1 & 0 & 0 & 0.33 & 0 & 0.00 \\
\hline Netherlands & 0 & 0 & 1 & I & 0 & 0.10 & 2 & 0.00 \\
\hline Peru & 1 & $\mathbf{0}$ & 0 & I & 0 & 0.20 & 2 & 0.00 \\
\hline Philippines & 0 & 0 & 0 & 1 & 1 & 0.10 & 4 & 0.50 \\
\hline Portugal & 0 & 0 & 0 & 0 & 0 & 0.05 & 2 & 0.50 \\
\hline Spain & 0 & 0 & 1 & 0 & 1 & 0.05 & 2 & 0.00 \\
\hline Turkey & 0 & 0 & 0 & 0 & $\mathbf{0}$ & 0.10 & 2 & 0.00 \\
\hline Uruguay & 1 & 0 & 1 & 0 & 1 & 0.20 & 1 & 0.20 \\
\hline Venezuela & 0 & 0 & 0 & 0 & 0 & 0.20 & 1 & 0.00 \\
\hline Ave- French origin & 0.24 & 0.09 & 0.43 & 0.19 & 0.33 & 0.14 & 1.76 & 0.14 \\
\hline Austria & 0 & 1 & 1 & 0 & 0 & 0.05 & 2 & 0.00 \\
\hline Germany & 0 & 0 & i & 0 & 0 & 0.05 & 1 & 0.00 \\
\hline Japan & 1 & 0 & $\mathbf{0}$ & 0 & 1 & 0.03 & 3 & 0.00 \\
\hline South Korea & 1 & 0 & 0 & 0 & $\mathbf{0}$ & 0.05 & 2 & 0.00 \\
\hline Switzerland & 0 & 0 & 1 & 0 & 0 & 0.10 & 1 & 0.00 \\
\hline Taiwan & 0 & 0 & 1 & 1 & 1 & 0.03 & 3 & 0.00 \\
\hline Avg. German origin & 0.33 & 0.17 & 0.67 & 0.17 & 0.33 & 0.05 & 2.00 & 0.00 \\
\hline Denmark & 0 & 0 & 0 & 0 & I & 0.10 & 3 & 0.00 \\
\hline Finland & 0 & 0 & 0 & 0 & 0 & 0.10 & 2 & 0.00 \\
\hline Norway & 0 & I & 0 & 0 & 0 & 0.10 & 3 & 0.00 \\
\hline Sweden & 0 & 0 & 0 & 0 & 0 & $0.10^{\mathrm{c}}$ & 2 & 0.00 \\
\hline Avg Scandimavian origin & 0.00 & 0.25 & 0.00 & 0.00 & 0.25 & 0.10 & 2.50 & 0.00 \\
\hline \multirow[t]{2}{*}{ Total Avernge } & 0.22 & 0.22 & 0.27 & 0.16 & 0.53 & 0.11 & 2.44 & 0.06 \\
\hline & \multicolumn{8}{|c|}{ Panel B Tests of Means (t-statistic) } \\
\hline Common vs. Civil Law & -0.03 & $2.16^{b}$ & $-4.65 !$ & 0.05 & 4.48 “ & -1.14 & $5.24^{\cdot}$ & $2.82^{\circ}$ \\
\hline England vs. France & -0.11 & $2.25^{\circ}$ & $-3.87^{\bullet}$ & -0.19 & $4.14^{\circ}$ & $-1.98^{b}$ & $5.13^{*}$ & $2.99^{\circ}$ \\
\hline England vs. Germany & -0.52 & 0.98 & $-3.16^{b}$ & 0.00 & $3.13^{\circ}$ & $2.42^{\mathrm{C}}$ & $3.66^{\star}$ & 0.00 \\
\hline England vs. Scandinavia & $2.20^{\circ}$ & 0.50 & 0.00 & $1.84^{\mathrm{c}}$ & $3.25^{\circ}$ & -0.87 & $2.14^{b}$ & 0.00 \\
\hline France vs. Germany & -0.45 & -0.47 & -1.01 & 0.13 & 0.00 & $2.34^{b}$ & -0.47 & $2.99^{*}$ \\
\hline France vs. Scandinavia & $2.50^{\mathrm{b}}$ & -0.85 & $3.51^{\circ}$ & $2.17^{\mathrm{b}}$ & 0.31 & $1.90^{\mathrm{c}}$ & -1.25 & $2.99^{\circ}$ \\
\hline Germany vs. Scandinavia & 1.58 & -0.29 & $3.16^{\circ}$ & 1.00 & 0.25 & $-4.62:$ & -0.98 & 0.00 \\
\hline
\end{tabular}


Table 3: Creditor Rights around the World

This table classifies countries by legal origin and shows the creditors' rights for each country. Exact definitions for each creditors' right can be found in Table 1 . Panel $B$ gives the tests of means for the different legal origins.

\begin{tabular}{|c|c|c|c|c|c|}
\hline \multirow{2}{*}{ COUNTRY } & \multicolumn{5}{|c|}{ Panel A CREDITORS' RIGHTS ( 1 = exists in the law) } \\
\hline & $\begin{array}{c}\text { Restrictions for } \\
\text { going into reorganization }\end{array}$ & $\begin{array}{c}\text { Automatic } \\
\text { Stay on assets }\end{array}$ & $\begin{array}{c}\text { Secured Creditors } \\
\text { first paid }\end{array}$ & $\begin{array}{c}\text { Management } \\
\text { stays in reorganization }\end{array}$ & $\begin{array}{l}\text { Legal Reserve required } \\
\text { as a } \% \text { of capital }\end{array}$ \\
\hline Australia & $\mathbf{0}$ & 1 & 1 & $\mathbf{I}$ & 0.00 \\
\hline Canads & $\mathbf{0}$ & 1 & 1 & $\mathbf{I}$ & 0.00 \\
\hline Hongkong & 1 & 0 & 1 & 0 & 0.00 \\
\hline India & 1 & 0 & 1 & 0 & 0.00 \\
\hline Ireland & $\mathbf{0}$ & 1 & I & 1 & 0.00 \\
\hline Imael & I & 0 & 1 & 0 & 0.00 \\
\hline Kenya & 1 & 0 & I & 0 & 0.00 \\
\hline Malaysia & 1 & 0 & 1 & $\mathbf{0}$ & 0.00 \\
\hline New Zealand & 1 & 0 & 0 & 0 & 0.00 \\
\hline Nigeria & 1 & 0 & $\mathbf{I}$ & 0 & 0.00 \\
\hline Pakistan & I & $\mathbf{0}$ & 1 & 0 & 0.00 \\
\hline Singapore & 1 & 0 & 1 & 0 & 0.00 \\
\hline South Africa & 1 & 1 & 1 & 0 & 0.00 \\
\hline Sri Lenka & na & na & na & $\mathbf{n a}$ & 0.00 \\
\hline Thailand & 0 & 0 & 1 & 0 & 0.10 \\
\hline UK & 1 & 0 & 1 & 0 & 0.00 \\
\hline US & 0 & 1 & 1 & 1 & 0.00 \\
\hline Zimbabwe & 1 & $\mathbf{0}$ & 1 & 0 & 0.00 \\
\hline Ave. Engllsh origin & 0.71 & 0.29 & 0.94 & 0.24 & 0.01 \\
\hline Argenting & 0 & 1 & 1 & 1 & 0.20 \\
\hline Belgium & 0 & 0 & 1 & 1 & 0.10 \\
\hline Brazil & 1 & 1 & 0 & 1 & 0.20 \\
\hline Chile & 1 & 1 & 1 & 1 & 0.20 \\
\hline Colombia & 0 & 1 & $\mathbf{0}$ & 1 & 0.50 \\
\hline Ecusdor & 1 & 0 & 1 & 0 & 0.50 \\
\hline Egypt & 1 & 0 & 1 & 0 & 0.50 \\
\hline France & 0 & I & 0 & 1 & 0.10 \\
\hline Greece & 0 & 1 & 0 & 0 & 0.33 \\
\hline Indonesia & 1 & 0 & 1 & 0 & 0.00 \\
\hline Italy & 1 & 1 & 1 & 1 & 0.20 \\
\hline Jordan & $\mathbf{n a}$ & na & na & na & 0.00 \\
\hline Mexico & 0 & 1 & 0 & 1 & 0.20 \\
\hline Netherlands & 1 & 1 & 1 & 1 & 0.00 \\
\hline Peru & 0 & 1 & 0 & 1 & 0.20 \\
\hline Philippines & $\mathbf{0}$ & 1 & 0 & 1 & 0.00 \\
\hline Portugal & 0 & 1 & 1 & 1 & 0.20 \\
\hline Spain & 0 & $\mathbf{0}$ & 1 & 1 & 0.20 \\
\hline Turkey & 1 & 1 & 1 & 1 & 0.20 \\
\hline Uruguay & $\mathbf{0}$ & 1 & 1 & 0 & 0.20 \\
\hline Venezuela & $\mathbf{n a}$ & na & 1 & na & 0.10 \\
\hline Avg. French origin & 0.42 & 0.74 & 0.68 & 0.74 & 0.20 \\
\hline Austria & 1 & 0 & I & 1 & 0.10 \\
\hline Germany & 1 & 0 & 1 & I & 0.10 \\
\hline Japan & 0 & 1 & 1 & 0 & 0.25 \\
\hline South Korea & 0 & $\mathbf{0}$ & I & $\mathbf{0}$ & 0.50 \\
\hline Switerland & 0 & 1 & 1 & 1 & 0.50 \\
\hline Taiwan & 0 & 0 & 1 & 1 & 0.20 \\
\hline AvE. German origin & 0.33 & 0.33 & 1.00 & 0.67 & 0.28 \\
\hline Denmark & 1 & 0 & 1 & 1 & 0.25 \\
\hline Finland & $\mathbf{0}$ & 1 & I & 1 & 0.00 \\
\hline Norway & 1 & 1 & 1 & 1 & 0.20 \\
\hline Sweden & 1 & 1 & 1 & 1 & 0.20 \\
\hline Avg. Seandinavinn origin & 0.75 & 0.75 & 1.00 & 1.00 & 0.16 \\
\hline \multirow[t]{2}{*}{ Total Average } & 0.54 & 0.52 & 0.85 & $\mathbf{0 . 5 7}$ & 0.13 \\
\hline & \multicolumn{5}{|c|}{ Panel B Table of Means (t-statistics) } \\
\hline Common Law vs. Civil Law & $1.71^{\mathrm{c}}$ & $-2.47^{\prime}$ & 1.59 & $-4.05^{\prime}$ & $-5.47^{\star}$ \\
\hline England vs. France & $1.74^{\circ}$ & $-2.888^{\prime}$ & $2.34^{6}$ & $-3.54^{\circ}$ & $-5.19^{\bullet}$ \\
\hline England vs. Germany & 1.63 & -0.17 & -1.00 & $-1.99^{c}$ & $-6.35^{\circ}$ \\
\hline England vs. Scandinavia & -0.17 & $-1.73^{c}$ & -1.00 & $-7.21^{\circ}$ & $-5.90^{\circ}$ \\
\hline France vs. Germany & 0.37 & $1.84^{\mathrm{C}}$ & $-3.24^{*}$ & 0.39 & -1.05 \\
\hline France vs. Scandinavia & -1.18 & -0.05 & $-3.24^{*}$ & $-2.52^{b}$ & 0.42 \\
\hline Germany vs. Scandinavia & -1.26 & -1.26 & 0.00 & -1.58 & 1.09 \\
\hline
\end{tabular}


Table 4: Investors Rights, Legal Origin and GNP Regressions

Seemingly Unrelated Regressions (SURE) of the cross section of 49 countries around the world. The dependent variables are: (1) one share-one vote ; (2) proxy by mail; (3) shares blocked before meeting; (4) cumulative voting; (5) oppressed minorities mechanism (6) percentage of share capital to call an extraordinary shareholders' meeting (ESM); (7) mandatory dividend; (8) restrictions on reorganization; (9) automatic stay on assets (10) secured creditors' first (11) management stays in reorganization; (12) legal reserve. The independent variables are (1) the log of GNP per capita and the set of "legal origins" dummies which include (a) "French Origin"; (b) "German Origin"; (c). "Scandinavian Origin"; and a Constant.

\begin{tabular}{|c|c|c|c|c|c|c|}
\hline \multirow[b]{2}{*}{ DEPENDENT VARS. } & \multicolumn{6}{|c|}{ Independent Variables } \\
\hline & $\begin{array}{l}\text { Log of GNP } \\
\text { per Capita }\end{array}$ & $\begin{array}{l}\text { French } \\
\text { Origin } \\
\end{array}$ & $\begin{array}{l}\text { German } \\
\text { Origin } \\
\end{array}$ & $\begin{array}{l}\text { Scandinavian } \\
\text { Origin } \\
\end{array}$ & Constant & \\
\hline \multicolumn{7}{|l|}{ Shareholders' Rights } \\
\hline One Share -One Vote & $\begin{array}{l}-0.0111 \\
(0.0502)\end{array}$ & $\begin{array}{c}0.0284 \\
(0.1481)\end{array}$ & $\begin{array}{c}0.1156 \\
(0.2250)\end{array}$ & $\begin{array}{c}0.2152 \\
(0.2626)\end{array}$ & $\begin{array}{c}0.3271 \\
(0.4293)\end{array}$ & $\begin{array}{l}\text { Num.of Obs }=46 \\
" R^{2 *}=.0362\end{array}$ \\
\hline Proxy by Mail & $\begin{array}{l}0.1459 \\
(0.0426)\end{array}$ & $\begin{array}{l}-0.31355^{4} \\
(0.1259)\end{array}$ & $\begin{array}{l}-0.4758^{2} \\
(0.1913)\end{array}$ & $\begin{array}{l}-0.4251^{c} \\
(0.2232)\end{array}$ & $\begin{array}{l}-0.7964^{b} \\
(0.3648)\end{array}$ & $\begin{array}{l}\text { Num.of Obs }=46 \\
" R^{2 "}=.3037\end{array}$ \\
\hline $\begin{array}{l}\text { Shares Blocked } \\
\text { before Meeting }\end{array}$ & $\begin{array}{r}0.1160^{2} \\
(0.0396)\end{array}$ & $\begin{array}{l}0.4681^{\AA} \\
(0.1168)\end{array}$ & $\begin{array}{l}0.4832^{\circ} \\
(0.1775)\end{array}$ & $\begin{array}{l}-0.2094 \\
(0.2071)\end{array}$ & $\begin{array}{l}-0.9609^{\circ} \\
(0.3386)\end{array}$ & $\begin{array}{l}\text { Num.of Obs }=46 \\
" R^{2=}=.4619\end{array}$ \\
\hline Cumulative Voting & $\begin{array}{l}-0.0261 \\
(0.0447)\end{array}$ & $\begin{array}{c}0.0353 \\
(0.1320)\end{array}$ & $\begin{array}{c}0.0316 \\
(0.2006)\end{array}$ & $\begin{array}{l}-0.1291 \\
(0.2340)\end{array}$ & $\begin{array}{c}0.3933 \\
(0.3826)\end{array}$ & $\begin{array}{l}\text { Num.of Obs }=46 \\
" R^{2 n}=.0303\end{array}$ \\
\hline $\begin{array}{l}\text { Oppressed Minorities } \\
\text { Mechanism }\end{array}$ & $\begin{array}{l}-0.0103 \\
(0.0482)\end{array}$ & $\begin{array}{l}-0.57333^{4} \\
(0.1422)\end{array}$ & $\begin{array}{l}-0.6241^{4} \\
(0.2161)\end{array}$ & $\begin{array}{l}-0.7097^{\circ} \\
(0.2522)\end{array}$ & $\begin{array}{c}0.8562^{b} \\
(0.4121)\end{array}$ & $\begin{array}{l}\text { Num. of Obs }=46 \\
" R^{2^{n}}=.3421\end{array}$ \\
\hline $\begin{array}{l}\text { Percentage of Share } \\
\text { Capital to call an } \\
\text { ESM }\end{array}$ & $\begin{array}{l}-0.0079 \\
(0.0071)\end{array}$ & $\begin{array}{r}0.0396^{c} \\
(0.0211)\end{array}$ & $\begin{array}{l}-0.0276 \\
(0.0320)\end{array}$ & $\begin{array}{c}0.0225 \\
(0.0373)\end{array}$ & $\begin{array}{c}0.1573^{b} \\
(0.0610)\end{array}$ & $\begin{array}{l}\text { Num. of Obs }=46 \\
“ R^{2 *}=.1883\end{array}$ \\
\hline Mandatory Dividends & $\begin{array}{l}-0.0138 \\
(0.0159)\end{array}$ & $\begin{array}{c}0.1507 \\
(0.0469)\end{array}$ & $\begin{array}{c}0.0219 \\
(0.0713)\end{array}$ & $\begin{array}{c}0.0249 \\
(0.0832)\end{array}$ & $\begin{array}{c}0.1146 \\
(0.1360)\end{array}$ & $\begin{array}{l}\text { Num. of } O b s=46 \\
" R^{2 *}=.2471\end{array}$ \\
\hline \multicolumn{7}{|l|}{ Creditors' Rights } \\
\hline $\begin{array}{l}\text { Restrictions on } \\
\text { Reorganization }\end{array}$ & $\begin{array}{l}-0.0952^{c} \\
(0.0545)\end{array}$ & $\begin{array}{l}-0.2802^{c} \\
(0.1610)\end{array}$ & $\begin{array}{l}-0.2219 \\
(0.2447)\end{array}$ & $\begin{array}{l}0.2160 \\
(0.2855)\end{array}$ & $\begin{array}{c}1.4945^{\circ} \\
(0.4667)\end{array}$ & $\begin{array}{l}\text { Num.of Obs }=46 \\
" R^{2 "}=.1645\end{array}$ \\
\hline $\begin{array}{l}\text { Automatic Stay on } \\
\text { Assets. }\end{array}$ & $\begin{array}{l}0.1129^{b} \\
(0.0509)\end{array}$ & $\begin{array}{l}0.4373^{\circ} \\
(0.1502)\end{array}$ & $\begin{array}{l}-0.1393 \\
(0.2283)\end{array}$ & $\begin{array}{l}0.2520 \\
(0.2663)\end{array}$ & $\begin{array}{l}-0.6410 \\
(0.4354)\end{array}$ & $\begin{array}{l}\text { Num.of } O b s=46 \\
" R^{2^{*}}=.2768\end{array}$ \\
\hline $\begin{array}{l}\text { Secured Creditors } \\
\text { First }\end{array}$ & $\begin{array}{c}0.0094 \\
(0.0408)\end{array}$ & $\begin{array}{l}-0.3101 \\
(0.1207)\end{array}$ & $\begin{array}{l}0.0438 \\
(0.1833)\end{array}$ & $\begin{array}{l}0.0417 \\
(0.2139)\end{array}$ & $\begin{array}{l}0.8625^{4} \\
(0.3497)\end{array}$ & $\begin{array}{l}\text { Num. of } \mathrm{Obs}=46 \\
{ }^{\prime R^{2^{*}}}=.1897\end{array}$ \\
\hline $\begin{array}{l}\text { Management Stays in } \\
\text { Reorganization }\end{array}$ & $\begin{array}{r}0.1389^{\circ} \\
(0.0452)\end{array}$ & $\begin{array}{l}0.4948^{2} \\
(0.1336)\end{array}$ & $\begin{array}{l}0.2116 \\
(0.2031)\end{array}$ & $\begin{array}{l}0.5138^{\circ} \\
(0.2369)\end{array}$ & $\begin{array}{l}-0.9154^{\mathrm{b}} \\
(0.3873)\end{array}$ & $\begin{array}{l}\text { Num.of Obs }=46 \\
" R^{2^{*}}=.4190\end{array}$ \\
\hline Legal Reserve & $\begin{array}{l}-0.0165 \\
(0.0138)\end{array}$ & $\begin{array}{l}0.2070^{\circ} \\
(0.0409)\end{array}$ & $\begin{array}{l}0.2951^{\mathrm{a}} \\
(0.0623) \\
\end{array}$ & $\begin{array}{l}0.1863^{\circ} \\
(0.0726) \\
\end{array}$ & $\begin{array}{c}0.1424 \\
(0.1188) \\
\end{array}$ & $\begin{array}{l}\text { Num. of Obs }=46 \\
{ }^{\prime R^{2 "}}=.4651\end{array}$ \\
\hline
\end{tabular}

$a=$ Significant at $1 \%$ level; $b=$ Significant at $5 \%$ level; $c=$ Significant at $10 \%$ level. 
TABLE 5: Legal Origin, Shareholder and Creditor Rights

The following table reports F-tests based on a SURE regression model. The dependent variable is the stack of shareholder and creditor rights by country and the independent variables are the log of GNP per capita and the set of dummies for the different legal origins. The four legal origins are: (1) English; (2) French; (3) German; and (4) Scandinavian. Panel A reports F-tests on the significance of legal origins for the set of shareholders' rights. Panel B reports F-tests on the significance of legal origins for the set of creditors' rights. Finally, panel C reports F-tests on the significance of legal origins for both sets of shareholder and creditor rights together. F-statistics are reported with their associated probability underneath in parenthesis.

PANEL A: Shareholder Rights

\begin{tabular}{|c|c|c|c|c|c|}
\hline \multicolumn{2}{|l|}{ Mother } & \multirow{2}{*}{$\frac{\text { France }}{\left(\begin{array}{c}11.66 \\
(0.0000)\end{array}\right.}$} & \multirow{2}{*}{$\begin{array}{c}\text { Germany } \\
\begin{array}{c}4.65 \\
(0.0007)\end{array}\end{array}$} & \multirow{2}{*}{$\begin{array}{c}\text { Scandinavia } \\
2.25 \\
(0.0496)\end{array}$} & \multirow{2}{*}{$\begin{array}{c}\begin{array}{c}\text { Mother "I" against the } \\
\text { world }(=0)\end{array} \\
\begin{array}{c}10.07 \\
(0.0000)\end{array}\end{array}$} \\
\hline England & $\begin{array}{l}\text { F statistic } \\
\text { (Prob }>\text { F) }\end{array}$ & & & & \\
\hline France & $\begin{array}{l}\text { F statistic } \\
(\text { Prob }>\text { F) }\end{array}$ & & $\begin{array}{c}1.97 \\
(0.0829)\end{array}$ & $\begin{array}{c}3.19 \\
(0.0086)\end{array}$ & $\begin{array}{c}7.75 \\
(0.0000)\end{array}$ \\
\hline Germany & $\begin{array}{l}\text { F statistic } \\
\text { (Prob }>\text { F) }\end{array}$ & & & $\begin{array}{l}2.41 \\
(0.0369)\end{array}$ & $\begin{array}{l}2.15 \\
(0.0588)\end{array}$ \\
\hline Scandinavia & $\begin{array}{l}\text { F statistic } \\
(\text { Prob }>\text { F) }\end{array}$ & & & & $\begin{array}{l}2.06 \\
(0.0688)\end{array}$ \\
\hline $\begin{array}{l}\text { All mothers are equal to each } \\
\text { other }\end{array}$ & $\begin{array}{l}\text { F statistic } \\
(\text { Prob }>\text { F) }\end{array}$ & & & & $\begin{array}{c}5.32 \\
(0.0000)\end{array}$ \\
\hline
\end{tabular}

PANEL B: Creditor Rights

\begin{tabular}{|c|c|c|c|c|c|}
\hline \multicolumn{2}{|l|}{ Mother } & \multirow{2}{*}{$\begin{array}{c}\text { France } \\
\begin{array}{c}11.36 \\
(0.0000)\end{array}\end{array}$} & \multirow{2}{*}{$\begin{array}{c}\text { Germany } \\
\begin{array}{c}6.18 \\
(0.0002)\end{array}\end{array}$} & \multirow{2}{*}{$\begin{array}{c}\text { Scandinavia } \\
\begin{array}{c}3.87 \\
(0.0058)\end{array}\end{array}$} & \multirow{2}{*}{$\begin{array}{c}\begin{array}{c}\text { Mother "I" against the } \\
\text { world (=0) }\end{array} \\
\begin{array}{c}13.17 \\
(\mathbf{0 . 0 0 0 0 )}\end{array}\end{array}$} \\
\hline England & $\begin{array}{l}\text { F statistic } \\
(\text { Prob }>\text { F })\end{array}$ & & & & \\
\hline France & $\begin{array}{l}\text { F statistic } \\
\text { (Prob > F) }\end{array}$ & & $\begin{array}{c}2.28 \\
(0.0643)\end{array}$ & $\begin{array}{c}1.03 \\
(0.4153)\end{array}$ & $\begin{array}{c}5.73 \\
(0.0004)\end{array}$ \\
\hline Germany & $\begin{array}{l}\text { F statistic } \\
(\text { Prob }>\text { F })\end{array}$ & & & $\begin{array}{c}1.58 \\
(0.1881)\end{array}$ & $\begin{array}{c}2.79 \\
(0.0288)\end{array}$ \\
\hline Scandinavia & $\begin{array}{l}\text { F statistic } \\
\text { (Prob > F) }\end{array}$ & & & & $\begin{array}{c}1.22 \\
(0.3157)\end{array}$ \\
\hline $\begin{array}{l}\text { All mothers are equal to each } \\
\text { other }\end{array}$ & $\begin{array}{l}\text { F statistic } \\
(\text { Prob }>\text { F) }\end{array}$ & & & & $\begin{array}{c}5.30 \\
(0.0000)\end{array}$ \\
\hline
\end{tabular}

PANEL C: Shareholder and Creditor Rights

\begin{tabular}{||ll|c|c|c|c||}
\hline \multicolumn{1}{|c|}{ Mother } & France & Germany & Scandinavia & $\begin{array}{c}\text { Mother "l" against the } \\
\text { world (=) }\end{array}$ \\
\hline \hline England & $\begin{array}{l}\text { F statistic } \\
\text { (Prob > F) }\end{array}$ & $\begin{array}{c}12.95 \\
(0.0000)\end{array}$ & $\begin{array}{c}7.27 \\
(0.0000)\end{array}$ & $\begin{array}{c}2.71 \\
(0.0086)\end{array}$ & $\begin{array}{c}12.51 \\
(0.0000)\end{array}$ \\
\hline France & $\begin{array}{l}\text { F statistic } \\
\text { (Prob > F) }\end{array}$ & & $\begin{array}{c}2.24 \\
(0.0272)\end{array}$ & $\begin{array}{c}2.17 \\
(0.0325)\end{array}$ & $\begin{array}{c}5.93 \\
(0.0000)\end{array}$ \\
\hline Germany & $\begin{array}{c}\text { F statistic } \\
\text { (Prob > F) }\end{array}$ & & & $\begin{array}{c}2.55 \\
(0.0128)\end{array}$ & $\begin{array}{c}2.91 \\
(0.0050)\end{array}$ \\
\hline Scandinavia & $\begin{array}{l}\text { F statistic } \\
\text { (Prob > F) }\end{array}$ & & & $\begin{array}{c}2.01 \\
(0.0567)\end{array}$ \\
\hline $\begin{array}{l}\text { All mothers are equal to each } \\
\text { other }\end{array}$ & $\begin{array}{l}\text { F statistic } \\
\text { (Prob > F) }\end{array}$ & & & & $\begin{array}{c}6.05 \\
(0.0000)\end{array}$ \\
\hline
\end{tabular}




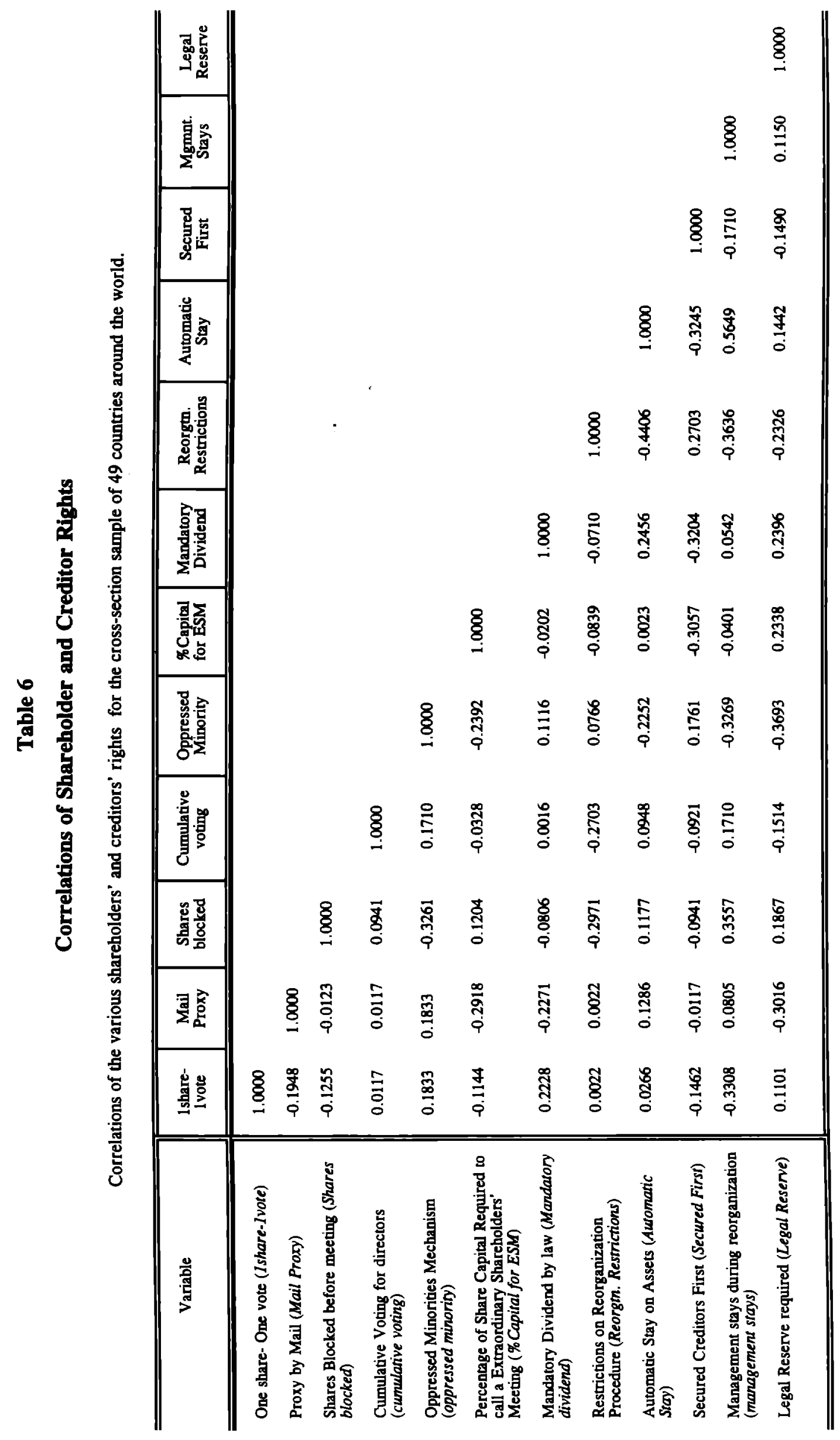


Table 7: Rule of Law

This table classifies countries by legal origin and shows the political variables for each country. Exact definitions for each of the variables can be found in Table 1. Panel B gives the tests of means for the different legal origins.

\begin{tabular}{|c|c|c|c|c|c|c|c|}
\hline \multirow[b]{2}{*}{ COUNTRY } & \multirow{2}{*}{$\begin{array}{l}\text { Panel A } \\
\text { Efficiency of } \\
\text { judicial system }\end{array}$} & \multirow[b]{2}{*}{ Rule of Law } & \multicolumn{3}{|c|}{ ENFORCEMENT VARIABLES } & \multirow{2}{*}{$\begin{array}{l}\text { ACCOUNTING } \\
\text { Rating on Accounting } \\
\text { Standards } \\
\end{array}$} & \multirow{2}{*}{$\begin{array}{l}\text { GNP PER } \\
\text { CAPITA } \\
\text { (U.S. \$) }\end{array}$} \\
\hline & & & Corruption & $\begin{array}{c}\text { Risk of } \\
\text { Expropriation }\end{array}$ & $\begin{array}{c}\begin{array}{c}\text { Risk of Contract } \\
\text { Repudiation }\end{array} \\
\end{array}$ & & \\
\hline $\begin{array}{l}\text { Australia } \\
\text { Canada } \\
\text { Hong Kong } \\
\text { India } \\
\text { Ireland } \\
\text { Israel } \\
\text { Kenya } \\
\text { Malaysia } \\
\text { New Zealand } \\
\text { Nigeria } \\
\text { Pakistan } \\
\text { Singapore } \\
\text { South Africa } \\
\text { Sri Lanka } \\
\text { Thailand } \\
\text { UK } \\
\text { US } \\
\text { Zimbabwe } \\
\text { Avg. English origin }\end{array}$ & $\begin{array}{l}10.00 \\
9.25 \\
10.00 \\
8.00 \\
8.75 \\
10.00 \\
5.75 \\
9.00 \\
10.00 \\
7.25 \\
5.00 \\
10.00 \\
6.00 \\
7.00 \\
3.25 \\
10.00 \\
10.00 \\
7.50 \\
8.15\end{array}$ & $\begin{array}{l}10.00 \\
10.00 \\
8.22 \\
4.17 \\
7.80 \\
4.82 \\
5.42 \\
6.78 \\
10.00 \\
2.73 \\
3.03 \\
8.57 \\
4.42 \\
1.90 \\
6.25 \\
8.57 \\
10.00 \\
3.68 \\
6.46\end{array}$ & $\begin{array}{c}8.52 \\
10.00 \\
8.52 \\
4.58 \\
8.52 \\
8.33 \\
4.82 \\
7.38 \\
10.00 \\
3.03 \\
2.98 \\
8.22 \\
8.92 \\
5.00 \\
5.18 \\
9.10 \\
8.63 \\
5.42 \\
7.06\end{array}$ & $\begin{array}{l}9.27 \\
9.67 \\
8.29 \\
7.75 \\
9.67 \\
8.25 \\
5.98 \\
7.95 \\
9.69 \\
5.33 \\
5.62 \\
9.30 \\
6.88 \\
6.05 \\
7.42 \\
9.71 \\
9.98 \\
5.61 \\
7.91\end{array}$ & $\begin{array}{l}8.71 \\
8.96 \\
8.82 \\
6.11 \\
8.96 \\
7.54 \\
5.66 \\
7.43 \\
9.29 \\
4.36 \\
4.87 \\
8.86 \\
7.27 \\
5.25 \\
7.57 \\
9.63 \\
9.00 \\
5.04 \\
7.41\end{array}$ & $\begin{array}{l}75 \\
74 \\
69 \\
57 \\
\text { na } \\
64 \\
\text { na } \\
76 \\
70 \\
59 \\
\text { na } \\
78 \\
70 \\
\text { na } \\
64 \\
78 \\
71 \\
\text { na } \\
\mathbf{6 9 . 6 2}\end{array}$ & $\begin{array}{r}17,500 \\
19,970 \\
18,060 \\
300 \\
13,000 \\
13,920 \\
270 \\
3,140 \\
12,600 \\
300 \\
430 \\
19,850 \\
2,980 \\
600 \\
2,110 \\
18,060 \\
24,740 \\
520 \\
9,353\end{array}$ \\
\hline $\begin{array}{l}\text { Argentina } \\
\text { Belgium } \\
\text { Brazil } \\
\text { Chile } \\
\text { Colombia } \\
\text { Ecuador } \\
\text { Egypt } \\
\text { France } \\
\text { Greece } \\
\text { Indonesia } \\
\text { Italy } \\
\text { Jordan } \\
\text { Mexico } \\
\text { Netherlands } \\
\text { Peru } \\
\text { Phillippines } \\
\text { Portugal } \\
\text { Spain } \\
\text { Turkey } \\
\text { Uruguay } \\
\text { Venezuela } \\
\text { Avg. French origin }\end{array}$ & $\begin{array}{l}6.00 \\
9.50 \\
5.75 \\
7.25 \\
7.25 \\
6.25 \\
6.50 \\
8.00 \\
7.00 \\
2.50 \\
6.75 \\
8.66 \\
6.00 \\
10.00 \\
6.75 \\
4.75 \\
5.50 \\
6.25 \\
4.00 \\
6.50 \\
6.50 \\
6.56\end{array}$ & $\begin{array}{l}5.35 \\
10.00 \\
6.32 \\
7.02 \\
2.08 \\
6.67 \\
4.17 \\
8.98 \\
6.18 \\
3.98 \\
8.33 \\
4.35 \\
5.35 \\
10.00 \\
2.50 \\
2.73 \\
8.68 \\
7.80 \\
5.18 \\
5.00 \\
6.37 \\
6.05\end{array}$ & $\begin{array}{l}6.02 \\
8.82 \\
6.32 \\
5.30 \\
5.00 \\
5.18 \\
3.87 \\
9.05 \\
7.27 \\
2.15 \\
6.13 \\
5.48 \\
4.77 \\
10.00 \\
4.70 \\
2.92 \\
7.38 \\
7.38 \\
5.18 \\
5.00 \\
4.70 \\
5.84\end{array}$ & $\begin{array}{l}5.91 \\
9.63 \\
7.62 \\
7.50 \\
6.95 \\
6.57 \\
6.30 \\
9.65 \\
7.12 \\
7.16 \\
9.35 \\
6.07 \\
7.29 \\
9.98 \\
5.54 \\
5.22 \\
8.90 \\
9.52 \\
7.00 \\
6.58 \\
6.89 \\
7.46\end{array}$ & $\begin{array}{l}4.91 \\
9.48 \\
6.30 \\
6.80 \\
7.02 \\
5.18 \\
6.05 \\
9.19 \\
6.62 \\
6.09 \\
9.17 \\
4.86 \\
6.55 \\
9.35 \\
4.68 \\
4.80 \\
8.57 \\
8.40 \\
5.95 \\
7.29 \\
6.30 \\
6.84\end{array}$ & $\begin{array}{l}45 \\
61 \\
54 \\
52 \\
50 \\
\text { na } \\
24 \\
69 \\
55 \\
\text { na } \\
62 \\
\text { na } \\
60 \\
64 \\
38 \\
65 \\
36 \\
64 \\
51 \\
31 \\
40 \\
51.17\end{array}$ & $\begin{array}{r}7,220 \\
21,650 \\
2,930 \\
3,170 \\
1,400 \\
1,200 \\
660 \\
22,490 \\
7,390 \\
740 \\
19,840 \\
1,190 \\
3,610 \\
20,950 \\
1,490 \\
850 \\
9,130 \\
13,590 \\
2,970 \\
3,830 \\
2,840 \\
7,102\end{array}$ \\
\hline $\begin{array}{l}\text { Austria } \\
\text { Germany } \\
\text { Japan } \\
\text { South Korea } \\
\text { Switzerdand } \\
\text { Taiwan } \\
\text { Avg. German origin }\end{array}$ & $\begin{array}{l}9.50 \\
9.00 \\
10.00 \\
6.00 \\
10.00 \\
6.75 \\
8.54\end{array}$ & $\begin{array}{l}10.00 \\
9.23 \\
8.98 \\
5.35 \\
10.00 \\
8.52 \\
8.68\end{array}$ & $\begin{array}{l}8.57 \\
8.93 \\
8.52 \\
5.30 \\
10.00 \\
6.85 \\
8.03\end{array}$ & $\begin{array}{l}9.69 \\
9.90 \\
9.67 \\
8.31 \\
9.98 \\
9.12 \\
9.45\end{array}$ & $\begin{array}{l}9.60 \\
9.77 \\
9.69 \\
8.59 \\
9.98 \\
9.16 \\
9.47\end{array}$ & $\begin{array}{l}54 \\
62 \\
65 \\
62 \\
68 \\
65 \\
62.67\end{array}$ & $\begin{array}{r}23,510 \\
23,560 \\
31,490 \\
7,660 \\
35,760 \\
10,425 \\
22,067\end{array}$ \\
\hline $\begin{array}{l}\text { Denmark } \\
\text { Finland } \\
\text { Norway } \\
\text { Sweden } \\
\text { Avg. Scandinavian origin }\end{array}$ & $\begin{array}{l}10.00 \\
10.00 \\
10.00 \\
10.00 \\
10.00\end{array}$ & $\begin{array}{l}10.00 \\
10.00 \\
10.00 \\
10.00 \\
10.00\end{array}$ & $\begin{array}{l}10.00 \\
10.00 \\
10.00 \\
10.00 \\
10.00\end{array}$ & $\begin{array}{l}9.67 \\
9.67 \\
9.88 \\
9.40 \\
9.66\end{array}$ & $\begin{array}{l}9.31 \\
9.15 \\
9.71 \\
9.58 \\
9.44\end{array}$ & $\begin{array}{c}62 \\
77 \\
74 \\
83 \\
\mathbf{7 4 . 0 0}\end{array}$ & $\begin{array}{l}26,730 \\
19,300 \\
25,970 \\
24,740 \\
24,185\end{array}$ \\
\hline Total Average & 7.67 & 6.85 & 6.90 & 8.05 & 7.58 & 60.93 & 11,156 \\
\hline Comman ys Civil & 127 & -0.77 & $\begin{array}{l}\text { Panel B: } \\
0.39\end{array}$ & $\begin{array}{c}\text { Tests of Mean } \\
-0.46\end{array}$ & ns (t-statistics) & $3.12^{\prime}$ & -0.94 \\
\hline England vs. France & $2.65^{\circ}$ & 0.51 & $1.79^{\circ}$ & 0.90 & 1.06 & $4.66^{\prime}$ & 0.85 \\
\hline England vs. Germany & -0.41 & $-1.82^{e}$ & -0.93 & $-2.19^{b}$ & $-2.79^{\circ}$ & $2.22^{\mathrm{b}}$ & $-2.86^{\bullet}$ \\
\hline England vs. Scandinavia & $-3.78^{\bullet}$ & -15.57 & $-5.38^{c}$ & $-2.06^{b}$ & $-2.26^{b}$ & -1.05 & $-3.24^{*}$ \\
\hline France vs. Germany & $-2.53^{\circ}$ & $-2.55^{\prime}$ & $-2.49^{\prime}$ & $-3.20^{\prime}$ & $-3.90^{*}$ & $-2.10^{b}$ & $-3.79^{\bullet}$ \\
\hline France vs. Scandinavia & $-9.34^{*}$ & $-20.80^{\circ}$ & $-9.77^{\bullet}$ & $-2.94^{\star}$ & $-3.17^{\bullet}$ & $-3.32^{\bullet}$ & $-4.28 \cdot$ \\
\hline Germany vs. Scandinavia & $-2.06^{\mathrm{C}}$ & $-11.29^{4}$ & $-2.88^{\circ}$ & -0.63 & 0.10 & $-2.66^{b}$ & -0.36 \\
\hline
\end{tabular}

$a=$ Significant at $1 \%$ level; $b=$ Significant at $5 \%$ level; $c=$ Significant at $10 \%$ level 
Ordinary least square regressions of the cross-section of 49 countries around the world. The dependent variables are: (1) efficiency of the judiciary system; (2) rule of law; (3) corruption; (4) risk of expropriation; (5) repudiation of contracts by government; and (6) accounting standards in each country. The independent variables for the first regression in each panel are the log of GNP per capita and the set of "legal origin" dummies (French, German, Scandinavian and the omitted dummy being English). The second regression in the panel of each dependent variable includes the log of GNP per capita and a dummy variable "Civil Law" which takes a value equal to 1 when the country belongs to the civil law tradition (i.e. all French, German and Scandinavian Codes), and 0 when the country belongs to the "Common Law" tradition (i.e. English Common Law). White (1980) standard errors are given in parentheses.

\begin{tabular}{|c|c|c|c|c|c|c|c|}
\hline \multirow[b]{2}{*}{ DEPENDENT VARS. } & \multirow[b]{2}{*}{$\begin{array}{l}\text { Log of GNP } \\
\text { per Capita }\end{array}$} & \multirow[b]{2}{*}{$\begin{array}{l}\text { Civil Law } \\
\text { dummy }\end{array}$} & \multirow[b]{2}{*}{$\begin{array}{l}\text { French } \\
\text { Origin }\end{array}$} & \multicolumn{2}{|c|}{ Independent Variables } & \multirow[b]{2}{*}{ Intercept } & \\
\hline & & & & $\begin{array}{l}\text { German } \\
\text { Origin }\end{array}$ & $\begin{array}{l}\text { Scandinavian } \\
\text { Origin }\end{array}$ & & \\
\hline $\begin{array}{l}\text { Efficiency of the } \\
\text { Judiciary System }\end{array}$ & $\begin{array}{c}0.8421 \\
(0.1374)\end{array}$ & ------ & $\begin{array}{l}-1.6609^{2} \\
(0.4544)\end{array}$ & $\begin{array}{l}-1.0305^{c} \\
(0.5717)\end{array}$ & $\begin{array}{c}0.2392 \\
(0.3364)\end{array}$ & $\begin{array}{c}1.2677 \\
(1.2185)\end{array}$ & $\begin{array}{l}\text { Num.of Obs }=49 \\
\text { Adjusted } R^{2}=.5330\end{array}$ \\
\hline $\begin{array}{l}\text { Eficiency of the } \\
\text { Judiciary System }\end{array}$ & $\begin{array}{l}0.9763 \\
(0.1312)\end{array}$ & $\begin{array}{l}-1.3774 \\
(0.4103)\end{array}$ & ------ & ------ & ------- & $\begin{array}{c}0.1702 \\
(1.2462)\end{array}$ & $\begin{array}{l}\text { Num. of Obs }=49 \\
\text { Adjusted } R^{2}=.4975\end{array}$ \\
\hline Rule of Law & $\begin{array}{l}1.4761^{\prime} \\
(0.1502)\end{array}$ & ------ & $\begin{array}{l}-0.5250 \\
(0.4325)\end{array}$ & $\begin{array}{l}-0.2715 \\
(0.5981)\end{array}$ & $\begin{array}{c}0.7174 \\
(0.4436)\end{array}$ & $\begin{array}{l}-5.6050^{\circ} \\
(1.2887)\end{array}$ & $\begin{array}{l}\text { Num.of Obs }=49 \\
\text { Adjusted } R^{2}=.7538\end{array}$ \\
\hline Rule of Law & $\begin{array}{c}1.5541^{\circ} \\
(0.1336)\end{array}$ & $\begin{array}{l}-0.3642 \\
(0.4156)\end{array}$ & ------ & ------ & ------ & $\begin{array}{l}-6.2421^{\bullet} \\
(1.1711)\end{array}$ & $\begin{array}{l}\text { Num.of Obs }=49 \\
\text { Adjusted } R^{2}=.7501\end{array}$ \\
\hline Corruption & $\begin{array}{l}1.30888^{\circ} \\
(0.1076)\end{array}$ & ------ & $\begin{array}{l}-1.3236^{4} \\
(0.3023)\end{array}$ & $\begin{array}{l}-1.2422^{2} \\
(0.4500)\end{array}$ & $\begin{array}{r}0.4369 \\
(0.2986)\end{array}$ & $\begin{array}{l}-3.6367^{a} \\
(0.9363)\end{array}$ & $\begin{array}{l}\text { Num.of Obs }=49 \\
\text { Adjusted } R^{2}=.7183\end{array}$ \\
\hline Corruption & $\begin{array}{c}1.40200^{\circ} \\
(0.0962)\end{array}$ & $\begin{array}{l}-1.1388 \\
(0.2929)\end{array}$ & ------- & ------ & ------- & $\begin{array}{l}-4.3986 \\
(0.8440)\end{array}$ & $\begin{array}{l}\text { Num. of Obs }=49 \\
\text { Adjusted } R^{2}=.6853\end{array}$ \\
\hline Risk of Expropriation & $\begin{array}{c}0.9098 \cdot \\
(0.0883)\end{array}$ & & $\begin{array}{l}-0.5164^{b} \\
(0.2386)\end{array}$ & $\begin{array}{l}-0.0009 \\
(0.1987)\end{array}$ & $\begin{array}{c}0.0054 \\
(0.2124)\end{array}$ & $\begin{array}{c}0.4732 \\
(0.7989)\end{array}$ & $\begin{array}{l}\text { Num.of Obs }=49 \\
\text { Adjusted } R^{2}=.7949\end{array}$ \\
\hline Risk of Expropriation & $\begin{array}{c}0.9679^{\circ} \\
(0.0747)\end{array}$ & $\begin{array}{l}-0.3855^{c} \\
(0.2066)\end{array}$ & -------- & -.--..-- & ------ & $\begin{array}{l}-0.0018 \\
(0.6958)\end{array}$ & $\begin{array}{l}\text { Num. of Obs }=49 \\
\text { Adjusted } R^{2}=.7911\end{array}$ \\
\hline $\begin{array}{l}\text { Repudiation of } \\
\text { Contracts by Govmnt. }\end{array}$ & $\begin{array}{c}0.9951 \\
(0.0788)\end{array}$ & ------ & $\begin{array}{l}-0.6459^{\circ} \\
(0.2388)\end{array}$ & $\begin{array}{l}0.3803^{b} \\
(0.1844)\end{array}$ & $\begin{array}{l}0.1300 \\
(0.1985)\end{array}$ & $\begin{array}{l}-0.7290 \\
(0.6870)\end{array}$ & $\begin{array}{l}\text { Num.of Obs }=49 \\
\text { Adjusted } R^{2}=.8326\end{array}$ \\
\hline $\begin{array}{l}\text { Repudiation of } \\
\text { Contracts by Govmnt. }\end{array}$ & $\begin{array}{r}1.0976^{2} \\
(0.0710)\end{array}$ & $\begin{array}{l}-0.4111^{c} \\
(0.2158)\end{array}$ & ------ & ----- & ------ & $\begin{array}{l}-1.5671^{*} \\
(0.6291)\end{array}$ & $\begin{array}{l}\text { Num. of Obs }=49 \\
\text { Adjusted } R^{2}=.8066\end{array}$ \\
\hline Accounting Standards & $\begin{array}{l}4.3348 \\
(1.1669)\end{array}$ & ------- & $\begin{array}{l}-17.366^{\star} \\
(2.7591)\end{array}$ & $\begin{array}{l}-11.890^{\circ} \\
(2.7271)\end{array}$ & $\begin{array}{l}-1.5272 \\
(4.4562)\end{array}$ & $\begin{array}{l}31.807^{\circledR} \\
(10.161)\end{array}$ & $\begin{array}{l}\text { Num.of Obs }=41 \\
\text { Adjusted } R^{2}=.5694\end{array}$ \\
\hline Accounting Standards & $\begin{array}{c}5.774^{\star} \\
(1.2426)\end{array}$ & $\begin{array}{l}-14.331^{\circ} \\
(2.6385)\end{array}$ & ------ & ------ & ---.- & $\begin{array}{l}19.249^{c} \\
(11.015)\end{array}$ & $\begin{array}{l}\text { Num.of Obs }=41 \\
\text { Adjusted } R^{2}=.4875\end{array}$ \\
\hline
\end{tabular}

$a=$ Significant at $1 \%$ level; $b=$ Significant at $5 \%$ level; $c=$ Significant at $10 \%$ level. 
Ordinary Least Square regressions of the cross-section of 49 countries around the world. The dependent variables are: (1) a "Mandatory Dividends" dummy which is equal to 1 if the law requires a mandatory dividend, and 0 otherwise; (2) a "Legal Reserves" dummy variable equal to 1 if the law requires the existence of a legal reserve, and 0 otherwise; and (3) a "Remedial Rights" dummy variable equal to 1 if the law requires either the existence of a mandatory dividend or the existence of a legal reserve. The independent variables are: (1) the log of GNP per capita which comes from; (2) the efficiency of the judiciary system; (3) the index of quality of accounting standards in the country; and (4) the set of "legal origin" dummies (French, German., Scandinavian, and the omitted dummy for English origin). White (1980) corrected standard errors are shown in parenthesis.

\begin{tabular}{|c|c|c|c|}
\hline \multirow[b]{2}{*}{ Independent Variables } & \multicolumn{3}{|c|}{ Dependent Variables } \\
\hline & Mandatory Dividends & Legal Reserves & Remedial Rights \\
\hline $\begin{array}{l}\text { Log of GNP } \\
\text { per capita }\end{array}$ & $\begin{array}{c}-0.0033 \\
(0.0336)\end{array}$ & $\begin{array}{c}-0.0040 \\
(0.0214)\end{array}$ & $\begin{array}{c}0.0651^{\mathrm{b}} \\
(0.0278)\end{array}$ \\
\hline Efficiency of the Judiciary & $\begin{array}{l}-0.0166 \\
(0.0157)\end{array}$ & $\begin{array}{c}-0.0071 \\
(0.0124)\end{array}$ & $\begin{array}{l}-0.1050^{\mathrm{a}} \\
(0.0383)\end{array}$ \\
\hline Accounting & $\begin{array}{l}-0.0004 \\
(0.0038)\end{array}$ & $\begin{array}{c}-0.0032 \\
(0.0023)\end{array}$ & $\begin{array}{l}-0.0049^{c} \\
(0.0029)\end{array}$ \\
\hline French Origin & $\begin{array}{c}0.1057 \\
(0.0864)\end{array}$ & $\begin{array}{l}0.1194^{b} \\
(0.0580)\end{array}$ & $\begin{array}{c}0.5826^{2} \\
(0.1563)\end{array}$ \\
\hline German Origin & $\begin{array}{c}0.0050 \\
(0.0658)\end{array}$ & $\begin{array}{c}0.2486^{4} \\
(0.0782)\end{array}$ & $\begin{array}{c}0.8004^{4} \\
(0.0938)\end{array}$ \\
\hline Scandinavian Origin & $\begin{array}{c}0.0244 \\
(0.0252)\end{array}$ & $\begin{array}{l}0.1838^{2} \\
(0.0495)\end{array}$ & $\begin{array}{l}0.7454^{4} \\
(0.2169)\end{array}$ \\
\hline Intercept & $\begin{array}{c}0.1389 \\
(0.1333)\end{array}$ & $\begin{array}{l}0.3286^{b} \\
(0.1452)\end{array}$ & $\begin{array}{c}0.7659^{b} \\
(0.3220)\end{array}$ \\
\hline Number of Observations & 41 & 41 & 41 \\
\hline Adjusted $\mathbf{R}^{2}$ & 0.0994 & 0.4159 & 0.7687 \\
\hline
\end{tabular}


Table 10: Large Shareholders around the World

The following table provides ownership of firms by large shareholders in the cross-section of 49 countries. The first column gives the average percentage of common shares owned by the 3 largest shareholders in the 10 largest domestic firms in the non-financial sector in each country. The second column provides the average percentage of common stock owned by the 3 largest shareholders excluding the government, that is, when the government was one of the largest shareholders it was substituted with the next largest shareholder. The third column shows the average percentage of common shares owned by the 3 largest shareholders in the ten largest non-financial, privatelyoumed-domestic firms in a given country. A firm is considered privately owned if the State is not a known shareholder in it. The fourth column gives the median ownership of the 3 largest shareholders in the 10 largest non-financial privately-owned-domestic firms. The last two columns provide average market capital of the 10 firms in each of the two samples of firms respectively.

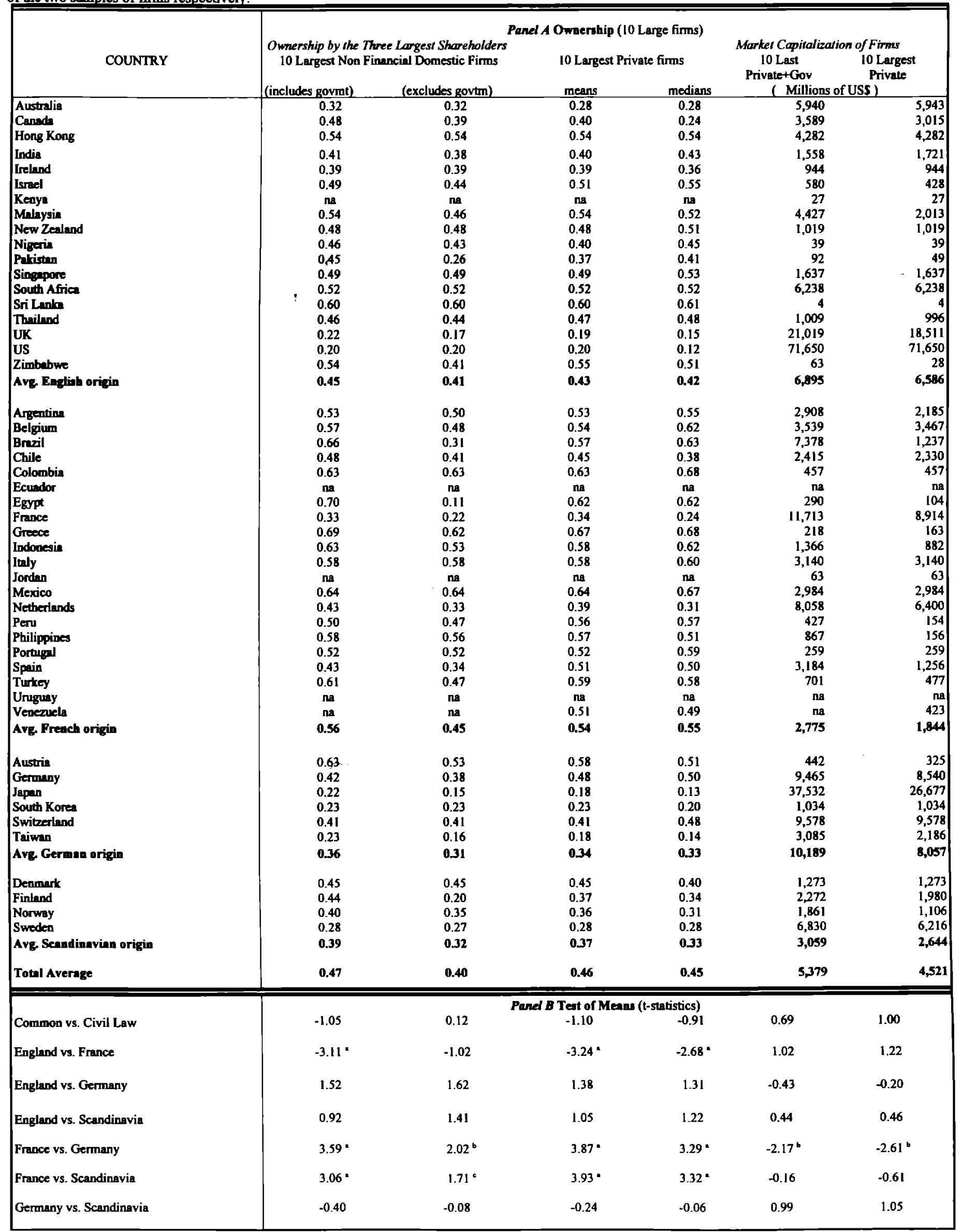




\section{TABLE 11: OWNERSHIP REGRESSIONS}

Ordinary least squares regressions of the cross section of 49 countries around the world. The dependent variable is "Ownership" which is the average percentage of common shares owned by the three largest shareholders in the ten largest privately-owned-domestic firms given in a given country. A firm is considered privately owned if the state is not a known shareholder in it. The independent variables are (1) log of GNP per capita; (2) log of GNP; (3) Gini Coefficient; (4) the rule of law in the country which refers to an index of law and order tradition in the country; (5) the index for accounting standards in the country; (6) French legal origin; (7) German legal origin; (8) Scandinavian legal origin; (9) the antidirectors shareholders' rights index (calculated as indicated in Table 1); (10) "one share-one vote" that equals one if the Company Law or Commercial Code of the country requires that ordinary shares carry one vote per share, and 0 otherwise; (11) mandatory dividend which equals the percentage of net income that the Company Law or the Commercial Code of the country requires firms to distribute as dividend among ordinary stockholders; (12) "secured creditors first" which equals 1 if secured creditors are ranked first in the distribution of the proceeds that result from the disposition of the assets of a bankrupt firm; (13) "automatic stay on assets" of the firm upon filing the reorganization petition and; (14) the legal reserve requirement which is the minimum percentage of total share capital mandated by Company Law or the Commercial Code of the country to avoid the dissolution of an existing firm. White (1980) corrected standard errors are shown in parenthesis.

\begin{tabular}{|c|c|c|}
\hline \multirow[b]{2}{*}{ Independent Variables } & \multirow[b]{2}{*}{ Basic Regression } & \multirow[b]{2}{*}{ Shareholder \& Creditor Rights } \\
\hline & & \\
\hline $\begin{array}{l}\text { Log of GNP } \\
\text { per capita }\end{array}$ & $\begin{array}{r}0.0077 \\
(0.0097)\end{array}$ & $\begin{array}{c}0.0611^{\prime} \\
(0.0185)\end{array}$ \\
\hline Log of GNP & $\begin{array}{l}-0.0442^{2} \\
(0.0119)\end{array}$ & $\begin{array}{l}-0.0321^{2} \\
(0.0099)\end{array}$ \\
\hline Gin Coefficient & $\begin{array}{l}0.0024^{\mathrm{c}} \\
(0.0014)\end{array}$ & $\begin{array}{c}0.0052 \\
(0.0017)\end{array}$ \\
\hline Rule of Law & & $\begin{array}{l}-0.0187^{b} \\
(0.0093)\end{array}$ \\
\hline Accounting & & $\begin{array}{l}-0.0044^{b} \\
(0.0020)\end{array}$ \\
\hline French Origin & $\begin{array}{l}0.1296^{2} \\
(0.0261)\end{array}$ & $\begin{array}{l}-0.0089 \\
(0.0634)\end{array}$ \\
\hline German Origin & $\begin{array}{l}-0.0113 \\
(0.0666)\end{array}$ & $\begin{array}{l}-0.1060 \\
(0.0691)\end{array}$ \\
\hline Scandinavian Origin & $\begin{array}{l}-0.0496 \\
(0.0371)\end{array}$ & $\begin{array}{r}-0.0432 \\
(0.0465)\end{array}$ \\
\hline $\begin{array}{l}\text { Antidirectors Shareholders } \\
\text { Rights }\end{array}$ & & $\begin{array}{l}-0.0517^{2} \\
(0.0131)\end{array}$ \\
\hline One Share-One Vote & & $\begin{array}{l}-0.0278 \\
(0.0293)\end{array}$ \\
\hline Mandatory Dividend & & $\begin{array}{c}0.1202 \\
(0.1265)\end{array}$ \\
\hline Secured Creditor First & & $\begin{array}{l}-0.0232 \\
(0.0337)\end{array}$ \\
\hline Automatic Stay on Assets & & $\begin{array}{l}-0.0473 \\
(0.0346)\end{array}$ \\
\hline Legal Reserve Required & & $\begin{array}{l}-0.1839 \\
(0.1141)\end{array}$ \\
\hline Intercept & $\begin{array}{l}0.7785^{a} \\
(0.1505)\end{array}$ & $\begin{array}{l}0.7382^{2} \\
(0.2107)\end{array}$ \\
\hline Number of Observations & 45 & 39 \\
\hline Adjusted $\mathbf{R}^{2}$ & 0.4885 & 0.5805 \\
\hline
\end{tabular}




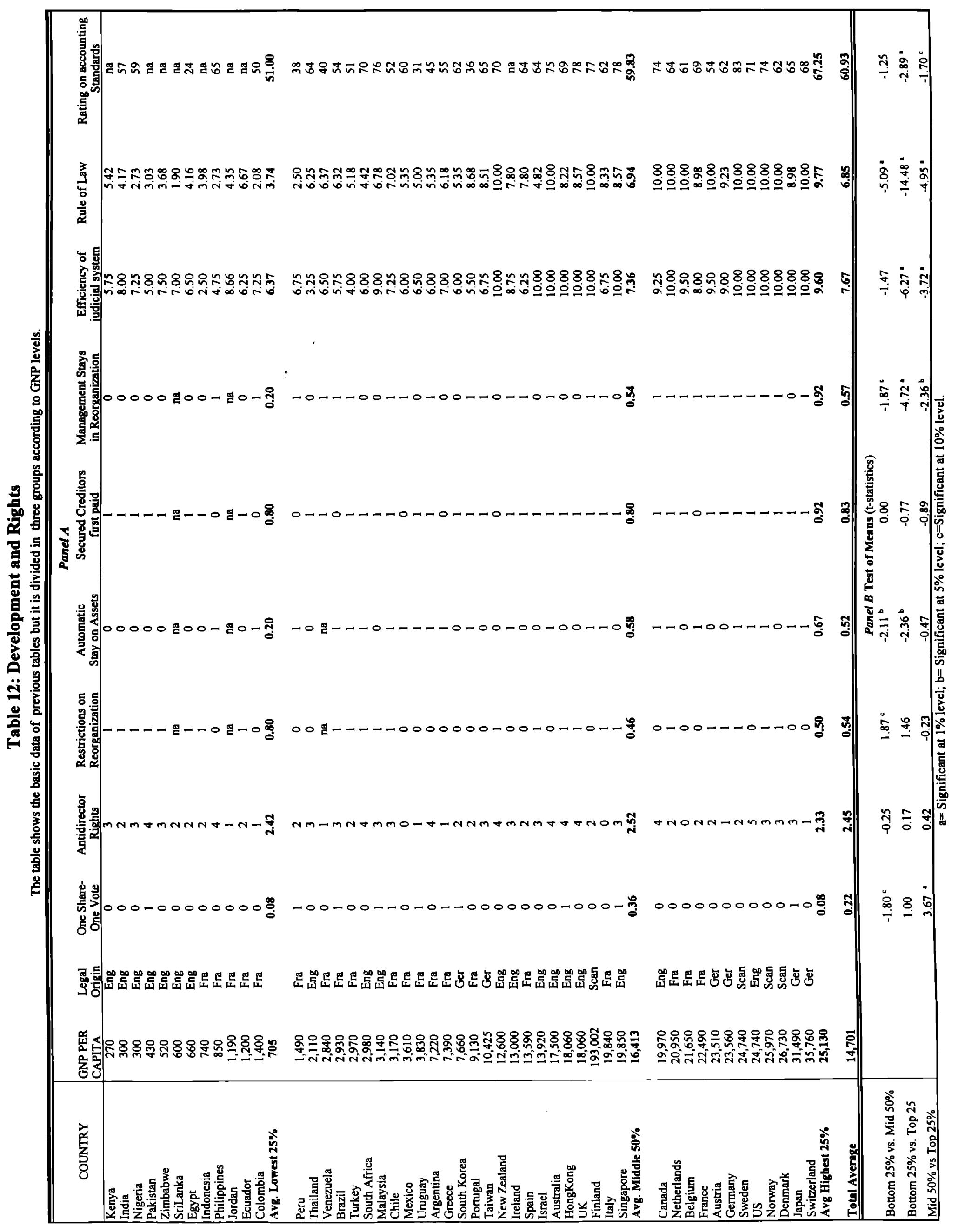


DATA APPENDIX

\begin{tabular}{|c|c|}
\hline COUNTRY & SOURCE \\
\hline \multicolumn{2}{|l|}{ ARGENTINA } \\
\hline CREDITORS & $\begin{array}{l}\text { Corporate Insolvency and Rescue:The International Dimension, Campbell and Collins, Kluwer Law and Taxation Publishers, } \\
1993 \\
\text { Cross- Border Insolvency : Comparative Dimensions, Ed. Ian F. Fletcher, UK National Committee of Comparative Law, UK } 199 \\
\text { Current Development in Intemational and Comparative Corporate Law, J.Ziegel, Ed. Oxford, Clarendon Press, } 1994 \\
\text { Division for Professional Education, American Bar Association, USA } 1987 \\
\text { Intemational Loan Workouts and Bankruptcies, Sponsored by Section of Corporate, Banking and Business Law and the } \\
\text { Division for Professional Education, American Bar Association, USA } 1987 \\
\text { Multinational Commercial Insolvency, American Bar Association 1993 } \\
\text { Questionnaire on Ceditors'Rights Against Business Debtors, Bianchi, Allende \& Brea, Buenos Aires, Argentina }\end{array}$ \\
\hline OWNERSHIP & $\begin{array}{l}\text { Argentina Company Handbook, 1995/96 Edition, IMF Editora Ltda., Buenos Aires, Republica Argentina. } \\
\text { Directory of Corporate Affiliations, National Register Pub. Co., New Jersey } 1995 \\
\text { Latin American Companies Database, Intemational Company Handbook, } 1995 \\
\text { Moody's Intemational Company Data, Moody's Investor's Service, } 1994 \text { Version, New York, USA } \\
\text { World Scope Global, Disclosure Inc. } 1996\end{array}$ \\
\hline \multicolumn{2}{|l|}{ AUSTRALIA } \\
\hline SHAREHOLDERS & $\begin{array}{l}\text { Several ADRs of different companies } \\
\text { Company Survey of Securities Law } \\
\text { Corporations Law in Australia, Tomasic, The Federation Press 1995, Sydney, Australia } \\
\text { Digest of Commercial Laws of the Commonwealth of Australia, Oceana Publications, Inc., April } 1995 \\
\text { Director of shareholders rights } \\
\text { Doing Business in Australia, The Price Waterhouse } 1993 \\
\text { FFO, The Economist Intelligence Unit, June } 1994 \\
\text { Guide to Companies Act 1993, Hickey, The Law book Co. Ltd, Sydney, Australia } \\
\text { ILS, The Economist Intelligence Unit, May } 1994 \\
\text { International Society of Securities Administrators 1994, Union Bank of Swizerland, Zurich Switzerland } \\
\text { IRRC, Global Shareholder Service, Proxy Voting Guide, Investor Responsibility Research Center, } 1995 \\
\text { Legal Aspects of Doing Business in Australia, William T. Mckay } \\
\text { Shareholders Rights Abroad, Stephen M. Davis, Investor Responsibility Research Center } \\
\text { The New Corporations Law, P. Gilles, 2nd Edition, The Federation Press, Sydney, Australia } 1992 \\
\text { The Price Watetrhouse European Companies Handbook 1992/1993 }\end{array}$ \\
\hline CREDITORS & $\begin{array}{l}\text { Cross- Border Insolvency : Comparative Dimensions, Ed. Ian F. Fletcher, UK National Committee of Comparative Law, UK } 199 \\
\text { Multinational Commercial Insolvency, American Bar Association } 1993 \\
\text { Corporate Insolvency and Rescue, Campbell, Denis and Anthony Collins, Ed. Boston, Kluwer and Taxation Publisher, } 1993 \\
\text { Current Development in International and Comparative Corporate Law, J.Ziegel, Ed. Oxford, Clarendon Press, } 1994 \\
\text { Cross-Border Insolvency: National and Comparative Studies, I. Fletcher, JCB Mohr, } 1992 \\
\text { Corporate Insolvency and Rescue: The Intemational Dimension, Cambell and Collins, Kluwer Law and Taxation Publishers } 199\end{array}$ \\
\hline OWNERSHIP & $\begin{array}{l}\text { Extel Financial Ltd., } 1995 \\
\text { Directory of Corporate Affiliations, National Register Pub. Co., New Jersey } 1995 \\
\text { The New Zealand Company Register 1994/95, 33th Edition, Mercantile Gazette Marketing Ltd., Bishopdale, Christchurch. } \\
\text { World Scope Global, Disclosure Inc. } 1996\end{array}$ \\
\hline
\end{tabular}




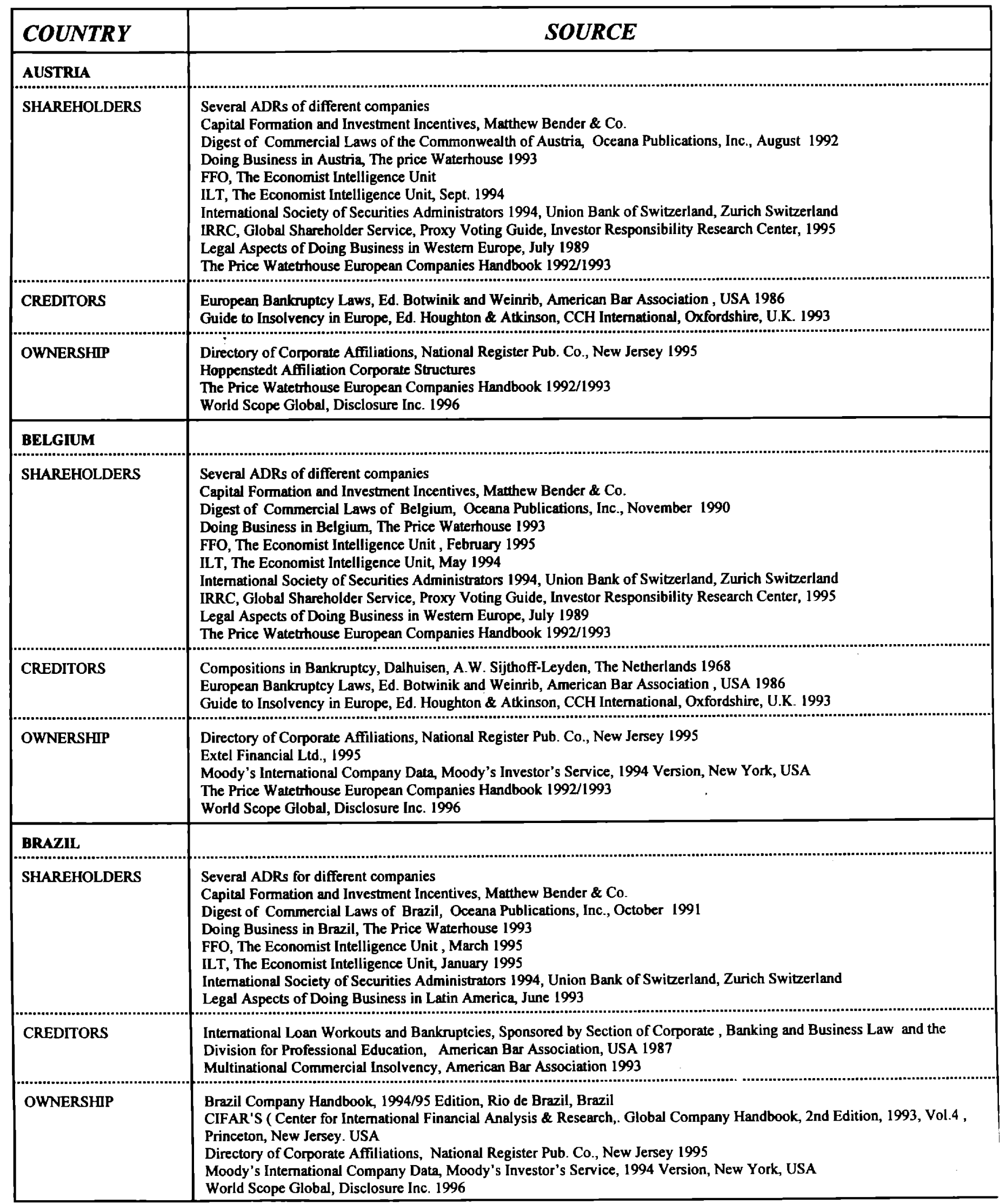




\begin{tabular}{|c|c|}
\hline COUNTRY & SOURCE \\
\hline \multicolumn{2}{|l|}{ CANADA } \\
\hline SHAREHOLDERS & $\begin{array}{l}\text { Several ADRs of different companies } \\
\text { Capital Formation and Investment Incentives, Matthew Bender \& Co. } \\
\text { Digest of Commercial Laws of Saskatchewan Canada, Oceana Publications, Inc.January } 1996 \\
\text { Digest of Commercial Laws of Quebec, Oceana Publications, Inc. August } 1992 \\
\text { Directory of Shareholders' Rights } \\
\text { Doing Business in Canada, The Price Waterhouse } 1993 \\
\text { FFO, The Economist Intelligence Unit, May } 1994 \\
\text { ILT, The Economist Intelligence Unit, October } 1994 \\
\text { International Society of Securities Administrators 1994, Union Bank of Switzerland, Zurich Switzerland } \\
\text { IRRC, Global Shareholder Service, Proxy Voting Guide, Investor Responsibility Research Center, } 1995 \\
\text { Legal Aspects of Doing Business in North America, June } 1993 \\
\text { Shareholders Rights Abroad, Stephen M. Davis, Investor Responsibility Research Center }\end{array}$ \\
\hline CREDITORS & $\begin{array}{l}\text { Cross- Border Insolvency : Comparative Dimensions, Ed. Ian F. Fletcher, UK National Committee of Comparative Law, UK } 199 \\
\text { International Loan Workouts and Bankruptcies, Sponsored by Section of Corporate, Banking and Business Law and the } \\
\text { Division for Professional Education, American Bar Association, USA } 1987 \\
\text { Multinational Commercial Insolvency, American Bar Association } 1993\end{array}$ \\
\hline OWNERSHIP & $\begin{array}{l}\text { Directory of Corporate Affiliations, National Register Pub. Co., New Jersey } 1995 \\
\text { Extel Financial Ltd., } 1995 \\
\text { Moody's Intemational Company Data, Moody's Investor's Service, } 1994 \text { Version, New York, USA } \\
\text { Survey of Industrials 1994, 68th Edition, The Financial Post Datagroup, Toronto, Canada }\end{array}$ \\
\hline \multicolumn{2}{|l|}{ CHILE } \\
\hline SHAREHOLDERS & $\begin{array}{l}\text { Several ADRs of different companies } \\
\text { Capital Formation and Investment Incentives, Matthew Bender \& Co. } \\
\text { Commercial Laws of Chile } \\
\text { Digest of Commercial Laws of Chile, Oceana Publications, Inc.,June } 1994 \\
\text { Doing Business in Chile, The Price Waterhouse } 1993 \\
\text { FFO, The Economist Intelligence Unit, January } 1995 \\
\text { ILT, The Economist Intelligence Unit, February } 1995 \\
\text { Intemational Society of Securities Administrators 1994, Union Bank of Switzerland, Zurich Switzerland } \\
\text { IRRC, Global Shareholder Service, Proxy Voting Guide, Investor Responsibility Research Center, } 1995 \\
\text { Legal Aspects of Doing Business in Latin America, July } 1993\end{array}$ \\
\hline CREDITORS & $\begin{array}{l}\text { Commercial Laws of Chile } \\
\text { Doing Business in Chile, The Price Waterhouse } 1993 \\
\text { Ley de Quiebras, Gonzalez, Ed. Publiley, Santiago, Chile } 1995 \\
\text { Manual de Derecho Commercial, R. Sandoval, Editorial Juridica Chile } 1990\end{array}$ \\
\hline OWNERSHIP & $\begin{array}{l}\text { CIFAR'S ( Center for Intemational Financial Analysis \& Research,. Global Company Handbook, 2nd Edition, 1993, Vol.4, } \\
\text { Princeton, New Jersey. USA } \\
\text { Extel Financial Lid., 1995 } \\
\text { Moody's International Company Data, Moody's Investor's Service, } 1994 \text { Version, New York, USA } \\
\text { World Scope Global, Disclosure Inc. } 1996\end{array}$ \\
\hline \multicolumn{2}{|l|}{ COLOMBIA } \\
\hline SHAREHOLDERS & $\begin{array}{l}\text { Several ADRs of different companies } \\
\text { Capital Formation and Investment Incentives, Matthew Bender \& Co. } \\
\text { Commercial Laws of Colombia } \\
\text { Digest of Commercial Laws of Colombia, Oceana Publications, Inc.,June } 1994 \\
\text { Doing Business in Colombia, The Price Waterouse, } 1993 \\
\text { FFO, The Economist Intelligence Unit, April } 1995 \\
\text { ILT, The Economist Intelligence Unit, January 1995 } \\
\text { Intemational Society of Securities Administrators 1994, Union Bank of Switzerland, Zurich Switzerland } \\
\text { Legal Aspects of Doing Business in Latin America, July } 1993 \\
\text { Sociedades Comerciales , Pinzon, Ed. Temis, Bogota, Colombia, } 1982\end{array}$ \\
\hline CREDITORS & $\begin{array}{l}\text { Commercial Laws of Colombia } \\
\text { Legal Aspects of Doing Business in Latin America, July } 1993\end{array}$ \\
\hline
\end{tabular}




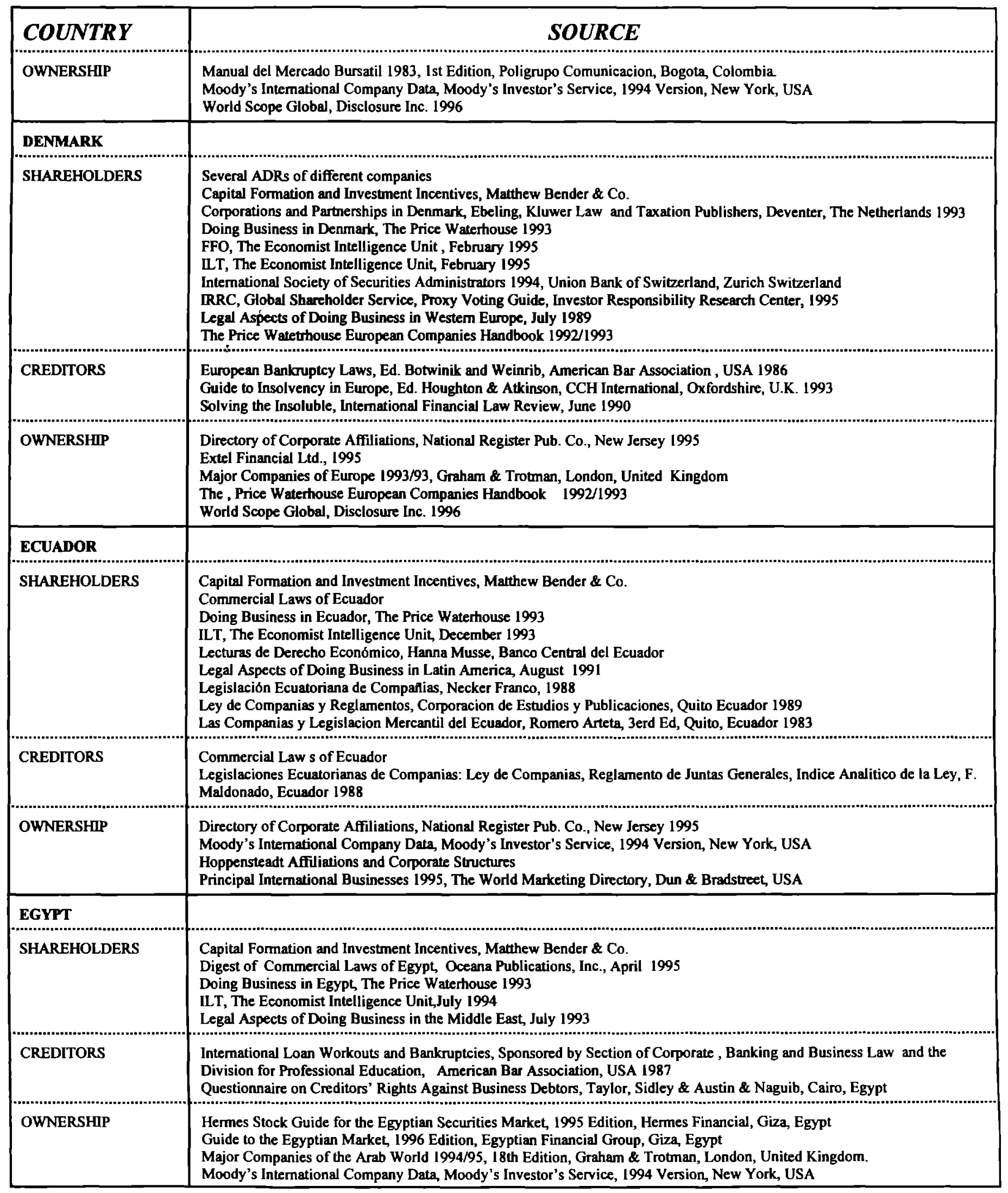




\begin{tabular}{|c|c|}
\hline COUNTRY & SOURCE \\
\hline \multicolumn{2}{|l|}{ FINLAND } \\
\hline SHAREHOLDERS & $\begin{array}{l}\text { Several ADRs of different companies } \\
\text { A Legal Guide to Scandinavian and Balhi Countries } \\
\text { Capital Formation and Investment Incentives, Matthew Bender \& Co. } \\
\text { Digest of Commercial Laws of Finland, Oceana Publications, Inc., April } 1994 \\
\text { Doing Business in Finland, The Price Waterhouse } 1993 \\
\text { ILT, The Economist Intelligence Unit, February } 1994 \\
\text { International Society of Securities Administrators 1994, Union Bank of Switzerland, Zurich Switzerland } \\
\text { IRRC, Global Shareholder Service, Proxy Voting Guide, Investor Responsibility Research Center, } 1995 \\
\text { Legal Aspects of Doing Business in Westem Europe, July } 1989 \\
\text { The Price Watethouse European Comapanies Handbook } 1992 / 1993\end{array}$ \\
\hline CREDITORS & Corporate Insolvency and Rescue: The International Dimension, Campbell \& Collins, Kluwer Law and Taxation Publishers, 199 \\
\hline OWNERSHIP & $\begin{array}{l}\text { CLFAR'S ( Center for International Financial Analysis \& Research,. Global Company Handbook, 2nd Edition, 1993, Vol.4, } \\
\text { Princeton, New Jersey. USA } \\
\text { Directory of Corporate Affiliations, National Register Pub. Co., New Jersey } 1995 \\
\text { The Price Waterhouse European Companies Handbook 1992/1993 } \\
\text { Extel Financial Ltd., } 1995 \\
\text { Major Companies of Europe 1993/93, Graham \& Trotman, London, United Kingdom } \\
\text { Capital Links in German Companies, 18th Edition, 1994, Commerzbank, Frankfurt, Germany } \\
\text { World Scope Global, Disclosure Inc. 1996 }\end{array}$ \\
\hline \multicolumn{2}{|l|}{ FRANCE } \\
\hline SHAREHOLDERS & $\begin{array}{l}\text { Several ADRs of different companies } \\
\text { Capital Formation and Investment Incentives, Matthew Bender \& Co. } \\
\text { Digest of Commercial Laws of France, Oceana Publications, Inc., September } 1993 \\
\text { Directory Global of Shareholders' Rights } \\
\text { Doing Business in France, The Price Waterhouse } 1993 \\
\text { Droit des Societes, M. Jeantin, 2nd Edition, Montchrestien, Paris } \\
\text { European Company Laws, Drury and Xuereb, Chapter } 7 \& \text { 9, Dartmouth, England } 1991 \\
\text { FFO, The Economist Intelligence Unit, September } 1994 \\
\text { French Company Law, Le Gall, Oyez Publishing London } 1974 \\
\text { ILT, The Economist Intelligence Unit, June } 1994 \\
\text { International Society of Securities Administrators 1994, Union Bank of Switzerland, Zurich Switzerland } \\
\text { IRRC, Global Shareholder Service, Proxy Voting Guide, Investor Responsibility Research Center, } 1995 \\
\text { Legal Aspects of Doing Business in Europe, September } 1992 \\
\text { Shareholders Rights Abroad, Stephen M. Davis, Investor Responsibility Research Center } \\
\text { The Price Watetrhouse European Comapanies Handbook 1992/1993 }\end{array}$ \\
\hline CREDITORS & $\begin{array}{l}\text { Compositions in Bankruptcy, Dalhuisen, A.W. Sijthoff-Leyden, The Netherlands } 1968 \\
\text { Corporate Bankruptcy and Reorganization Procedures in OECD and Central and Eastem European Countries, OECD, Paris, } \\
\text { France } 1994 \\
\text { Guide to Insolvency in Europe, Ed. Houghton \& Atkinson, CCH International, Oxfordshire, U.K. } 1993 \\
\text { European Bankruptcy Laws, Ed. Botwinik and Weinrib, American Bar Association, USA 1986 } \\
\text { International Loan Workouts and Bankruptcies, Sponsored by Section of Corporate, Banking and Business Law and the Divisio } \\
\text { for Professional Education, American Bar Association, USA } 1987 \\
\text { Multinational Commercial Insolvency, American Bar Association } 1993 \\
\text { European Insolvency Practitioners' Handbook, Kenneth \& Weiss, Ed. New York, St. Martin's Press, } 1984\end{array}$ \\
\hline OWNERSHIP & $\begin{array}{l}\text { CIFAR'S ( Center for Intemational Financial Analysis \& Research, Global Company Handbook, 2nd Edition, 1993, Vol.4, } \\
\text { Princeton, New Jersey. USA } \\
\text { Directory of Corporate Affiliations, National Register Pub. Co., New Jersey } 1995 \\
\text { Extel Financial Ltd., } 1995 \\
\text { Major Companies of Europe 1993/93, Graham \& Trotman, London, United Kingdom } \\
\text { The, Price Waterhouse European Companies Handbook 1992/1993 } \\
\text { World Scope Global, Disclosure Inc. } 1996\end{array}$ \\
\hline
\end{tabular}




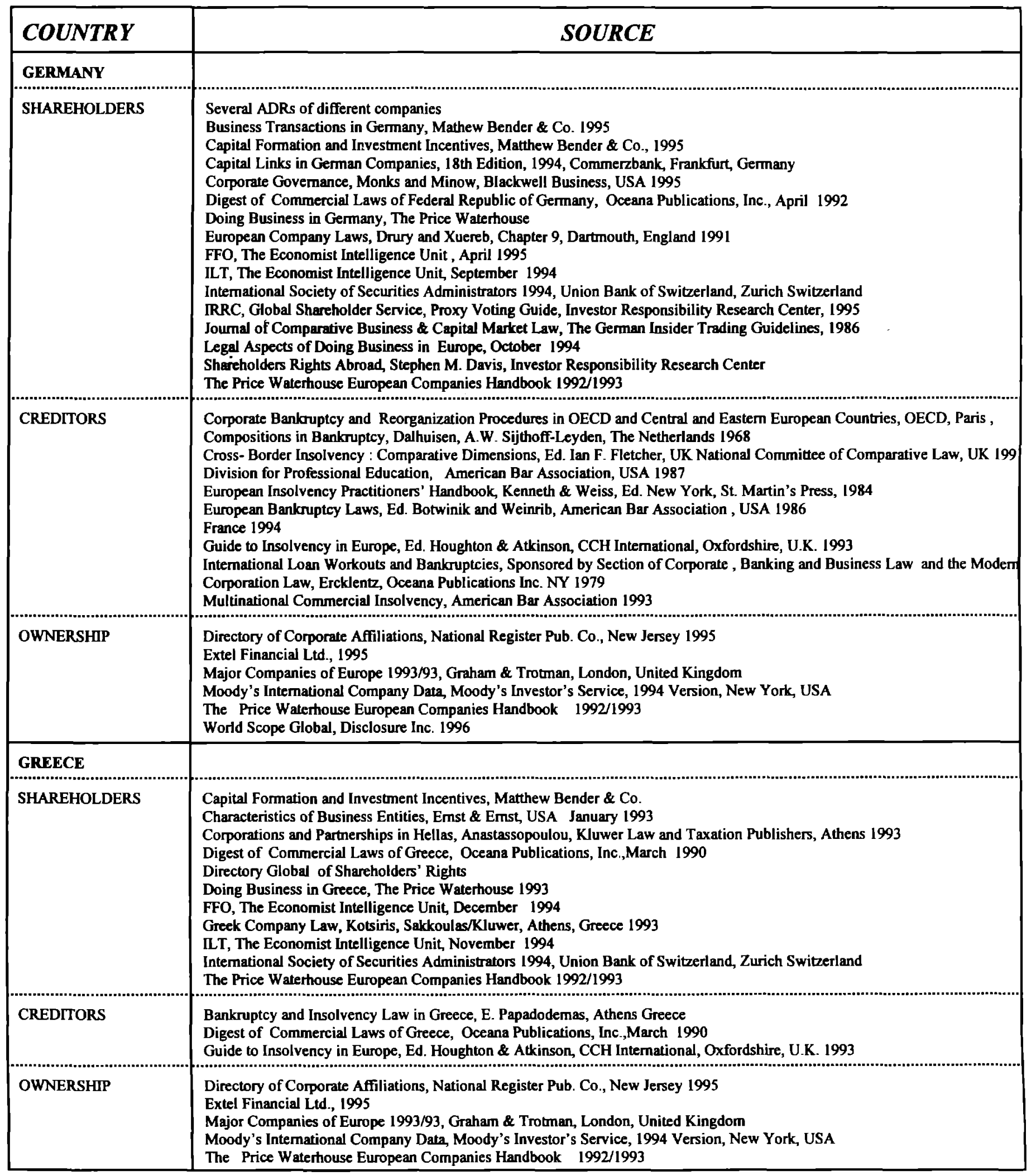




\begin{tabular}{|c|c|}
\hline COUNTRY & SOURCE \\
\hline \multicolumn{2}{|l|}{ HONK KONG } \\
\hline SHAREHOLDERS & $\begin{array}{l}\text { Business Law in Hong Kong, Sihombing, } 1991 \text { Edition, CCH Asia Limited } \\
\text { Capital Formation and Investment Incentives, Matthew Bender \& Co. } \\
\text { Company Law in Hong Kong, Wallace, 2nd Edition, Butterworths, } 1990 \\
\text { Corporate Govemance, Monks and Minow, Blackwell Business, USA } 1995 \\
\text { Digest of Commercial Laws of Hong Kong, Oceana Publications, Inc., March } 1992 \\
\text { Directory of Shareholders' Rights } \\
\text { Doing Business in Hong Kong. The Price Waterhouse } 1993 \\
\text { FFO, The Economist Intelligence Unit } \\
\text { Hong Kong Company Law, Sttot, 2nd Edition, Pitman } 1988 \\
\text { ILT, The Economist Intelligence Unit, December } 1994 \\
\text { International Society of Securities Administrators 1994, Union Bank of Switzerland, Zurich Switzerland } \\
\text { Global Shareholders' Service, Proxy Voting Guide, 1995 }\end{array}$ \\
\hline CREDITORS & $\begin{array}{l}\text { Company Law in Hong Kong, P. Wallace, 2nd Ed., Butterworths, Hong Kong } 1990 \\
\text { Doing Business in Hong Kong, The Price Waterhouse } 1993 \\
\text { Hong Kong Company Law, Sttot, 2nd Edition, Pitman } 1988\end{array}$ \\
\hline OWNERSHIP & $\begin{array}{l}\text { Asian Company Handbook, 1995/1996 Edition, Toyo Keizai Inc. } \\
\text { Directory of Corporate Affiliations, National Register Pub. Co., New Jersey } 1995 \\
\text { Extel Financial Ltd., } 1995 \\
\text { Moody's International Company Data, Moody's Investor's Service, } 1994 \text { Version, New York, USA }\end{array}$ \\
\hline \multicolumn{2}{|l|}{ INDLA } \\
\hline SHAREHOLDERS & $\begin{array}{l}\text { Capital Formation and Investment Incentives, Matthew Bender \& Co. } \\
\text { Company Law, Avtar Singh, Eastern Book Company, Delhi, India } \\
\text { Digest of Commercial Laws of Hong Kong, Oceana Publications, Inc., March } 1994 \\
\text { Doing Business in India, } 1993 \text { Price Waterhouse } \\
\text { FFO, The Economist Intelligence Unit, June } 1995 \\
\text { ILT, The Economist Intelligence Unit, May } 1995 \\
\text { Indian Company Law, N.K. Roy, The World Press Private Ltd, Calcutta, India } 1970 \\
\text { Intemational Society of Securities Administrators I994, Union Bank of Switzerland, Zurich Switzerland } \\
\text { Legal Aspects of Doing Business in Asia Pacific } \\
\text { The Company Law, Orient Law House, 4th Edition, New Delhi, India }\end{array}$ \\
\hline CREDITORS & $\begin{array}{l}\text { Digest of Commercial Laws of Hong Kong, Oceana Publications, Inc., March } 1994 \\
\text { Guide to Sick Companies, Dooger, Goldline Publishers, Delhi, India 1991 } \\
\text { Law and Practice of Company Winding Up, Goyle, Eastem Law House, Caleutta, India } 1987 \\
\text { The Companies Act. } 1956\end{array}$ \\
\hline OWNERSHIP & $\begin{array}{l}\text { Bloomberg's Electronic Database } \\
\text { CIFAR'S ( Center for International Financial Analysis \& Research,. Global Company Handbook, 2nd Edition, 1993, Vol.4, Prin } \\
\text { Jersey. USA } \\
\text { Directory of Corporate Affiliations, National Register Pub. Co., New Jersey } 1995 \\
\text { Moody's Intemational Company Data, Moody's Investor's Service, } 1994 \text { Version, New York, USA } \\
\text { The India Book 1992, A Guide to } 100 \text { Companies, } 1992 \text { Edition, Jardine Fleming, Bombay ,India } \\
\text { World Scope Global, Disclosure Inc. } 1996\end{array}$ \\
\hline \multicolumn{2}{|l|}{ INDONESIA } \\
\hline SHAREHOLDERS & $\begin{array}{l}\text { Capital Formation and Investment Incentives, Matthew Bender \& Co. } \\
\text { Company-Law in Indonesia, H. Perseroan, Pratomo, Legal Consultants } \\
\text { Digest of Commercial Laws of Indonesia, Oceana Publications, Inc., October } 1991 \\
\text { Doing Business in Indonesia, } 1993 \text { Price Waterhouse } \\
\text { FFO, The Economist Intelligence Unit, April 1995 } \\
\text { Global Shareholder Service, Proxy Voting Guide 1995, Investor Responsibility Research Center- } \\
\text { ILT, The Economist Intelligence Unit, January } 1995 \\
\text { ILTM } \\
\text { Global Shareholders' Service, Proxy Voting Guide, } 1995 \\
\text { Legal Aspects of Doing Business in Asia Pacific }\end{array}$ \\
\hline CREDITORS & Company-Law in Indonesia, H. Perseroan, Pratomo, Legal Consultants \\
\hline
\end{tabular}




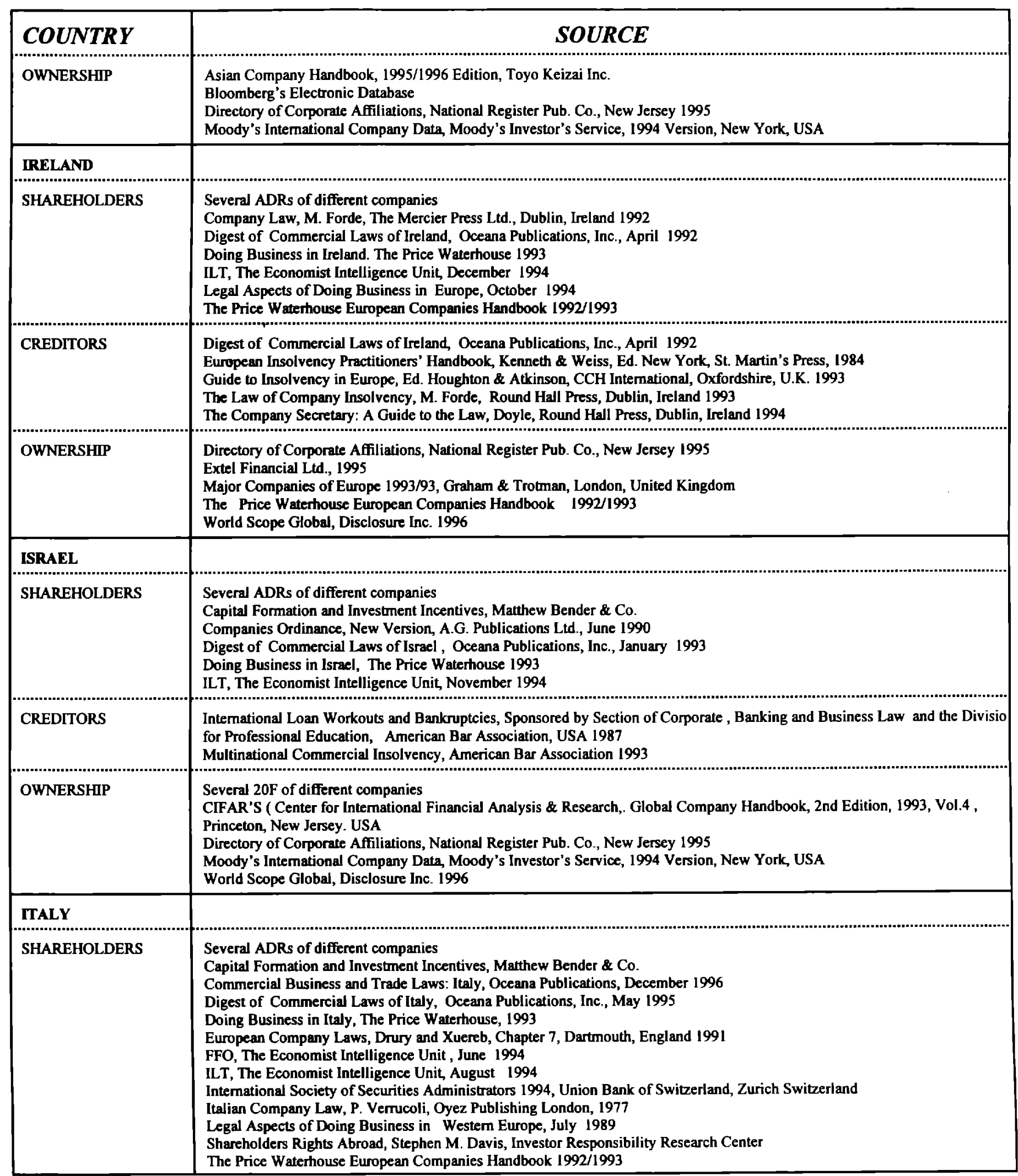




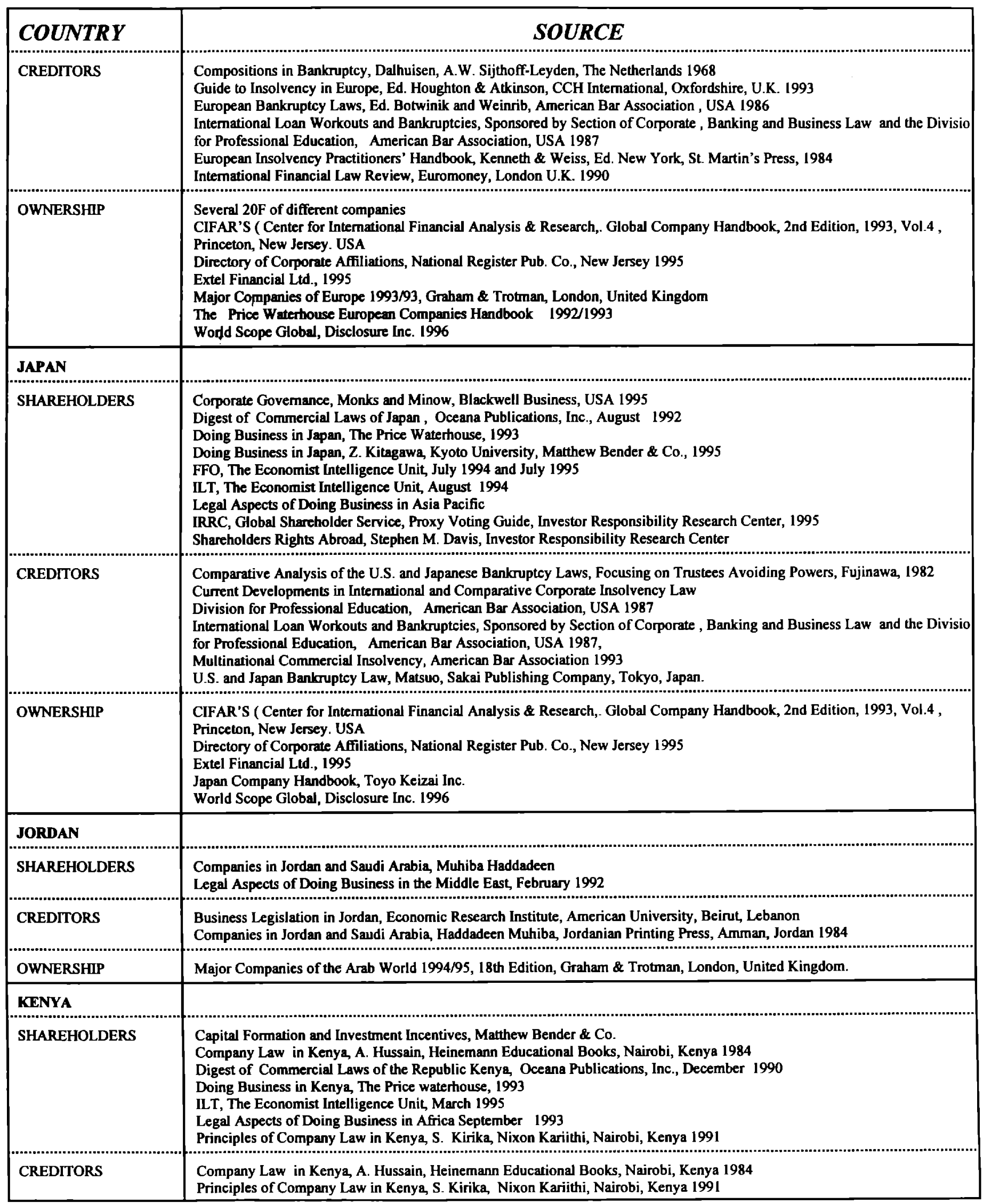




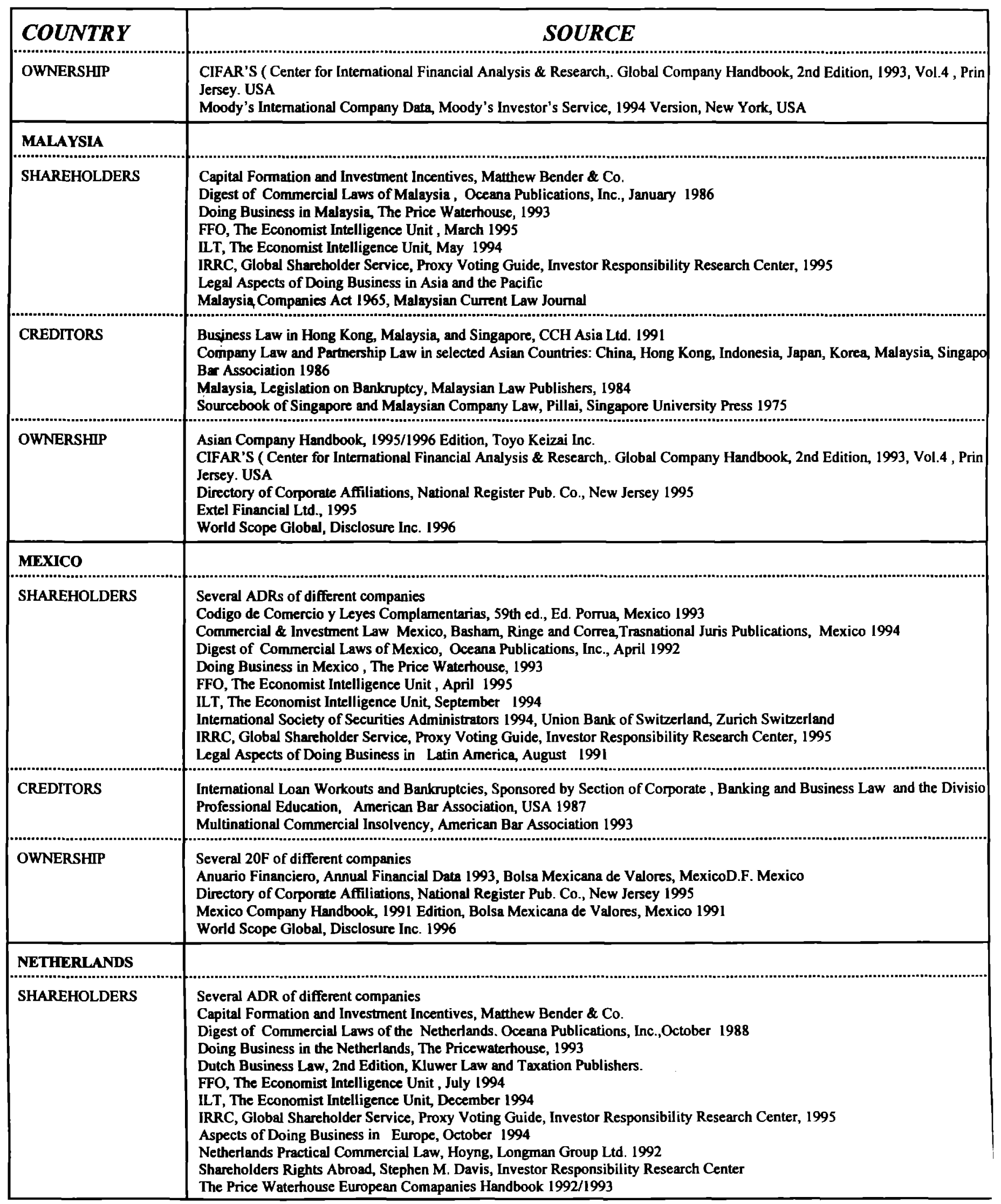




\begin{tabular}{|c|c|}
\hline COUNTRY & SOURCE \\
\hline CREDITORS & $\begin{array}{l}\text { Division for Professional Education, American Bar Association, USA } 1987 \\
\text { European Bankruptcy Laws, Ed. Botwinik and Weinrib, American Bar Association, USA } 1986 \\
\text { European Insolvency Practitioners' Handbook, Kenneth \& Weiss, Ed. New York, St. Martin's Press, } 1984 \\
\text { Guide to Insolvency in Europe, Ed. Houghton \& Atkinson, CCH Intemational, Oxfordshire, U.K. } 1993 \\
\text { International Loan Workouts and Bankruptcies, Sponsored by Section of Corporate, Banking and Business Law and the Divisio } \\
\text { for Professional Education, American Bar Association, USA 1987, } \\
\text { Multinational Commercial Insolvency, American Bar Association } 1993\end{array}$ \\
\hline OWNERSHIP & $\begin{array}{l}\text { Directory of Corporate Affiliations, National Register Pub. Co., New Jersey } 1995 \\
\text { Dutch Company Yearbook, 1995/96 Edition, The Hague, DELWEL, Netherlands } \\
\text { Extel Financial Ltd., 1995 } \\
\text { Major Companies of Europe 1993/93, Graham \& Trotman, London, Uinted Kingdom } \\
\text { Moody's International Company Data, Moody's Investor's Service, } 1994 \text { Version, New York, USA } \\
\text { The Price Waterhouse European Companies Handbook 1992/1993 } \\
\text { World Scope Global, Disclosure Inc. I996 }\end{array}$ \\
\hline NEW ZEALAND & \\
\hline SHAREHOLDERS & $\begin{array}{l}\text { Several ADRs of different companies } \\
\text { Capital Formation and Investment Incentives, Matthew Bender \& Co. } \\
\text { Company Survey of Securities Law } \\
\text { Commercial Law in New Zealand, Butterworths } \\
\text { Corporate Governance, Monks and Minow, Blackwell Business, USA } 1995 \\
\text { Digest of Commercial Laws of New Zealand, Oceana Publications, Inc., June } 1994 \\
\text { Director of sharebolders rights } \\
\text { Doing Business in New Zealand, The Price Waterhouse, } 1993 \\
\text { FFO, The Economist Intelligence Unit, April } 1995 \\
\text { Guidebook to N.Z. Comapanies and Securities Law, Beck and Borrowdale, 5th Edition, New Zealand } 1994 \\
\text { ILS, The Economist Intelligence Unit, May } 1994 \\
\text { International Society of Securities Administrators 1994, Union Bank of Switzerland, Zurich Switzerland } \\
\text { Introduction to Company Law in New Zealand, Northey, 9th Edition, Wellington, N.Z. 198 I } \\
\text { IRRC, Global Shareholder Service, Proxy Voting Guide, Investor Responsibility Research Center, } 1995 \\
\text { Legal Aspects of Doing Business in Asia and the Pacific, William T. Mckay } \\
\text { New Zealand Company Law Guide, CCH New Zealand Limited } 1993 \\
\text { The Price Watetrhouse European Comapanies Handbook 1992/1993 }\end{array}$ \\
\hline CREDITORS & $\begin{array}{l}\text { Commercial Law in New Zealand, Butterworths } \\
\text { Insolvency, New Zealand Law Society Seminar, Tony Agar and Gerard Coles, May } 1994\end{array}$ \\
\hline OWNERSHIP & $\begin{array}{l}\text { CIFAR'S ( Center for Intemational Financial Analysis \& Research,. Global Company Handbook, 2nd Edition, 1993, Vol.4, } \\
\text { Princeton, New Jersey. USA } \\
\text { Directory of Corporate Affiliations, National Register Pub. Co., New Jersey } 1995 \\
\text { Extel Financial Ltd., } 1995 \\
\text { Moody's International Company Data, Moody's Investor's Service, } 1994 \text { Version, New York, USA } \\
\text { The New Zealand Company Register 1994/95, 33th Edition, Mercantile Gazette Marketing Ltd., Bishopdale, Christchurch. } \\
\text { World Scope Global, Disclosure Inc. } 1996\end{array}$ \\
\hline \multicolumn{2}{|l|}{ NIGERIA } \\
\hline SHAREHOLDERS & $\begin{array}{l}\text { Capital Formation and Investment Incentives, Matthew Bender \& Co. } \\
\text { Digest of Commercial Laws of New Zealand, Oceana Publications, Inc., August } 1994 \\
\text { Doing Business in Nigeria, The Price Waterhouse, } 1993 \\
\text { Essays on Company Law, Ed. E.O. Akanki, University of Lagos, Nigeria } 1992 \\
\text { FFO, The Economist Intelligence Unit, June } 1994 \\
\text { ILS, The Economist Intelligence Unit, March } 1995 \\
\text { Legal Aspects of Doing Business in Africa, November } 1994 \\
\text { Nigeria Company Law. Ignatius A.Ayua, Graham Bum, U.K. I984 } \\
\text { Nigerian Company and Partnership Law, Kachikwu, 1st Ed., Mikzec Law Publications Ltd, Lagos Nigeria } 1988\end{array}$ \\
\hline CREDITORS & $\begin{array}{l}\text { Essays on Company Law, Ed. E.O. Akanki, University of Lagos, Nigeria } 1992 \\
\text { Nigeria Company Law. Ignatius A.Ayua, Graham Bum, U.K. } 1984\end{array}$ \\
\hline OWNERSHIP & $\begin{array}{l}\text { CIFAR'S ( Center for Intemational Financial Analysis \& Research, Global Company Handbook, 2nd Edition, 1993, Vol.4, } \\
\text { Princeton, New Jersey. USA } \\
\text { Moody's International Company Data, Moody's Investor's Service, } 1994 \text { Version, New York, USA }\end{array}$ \\
\hline
\end{tabular}




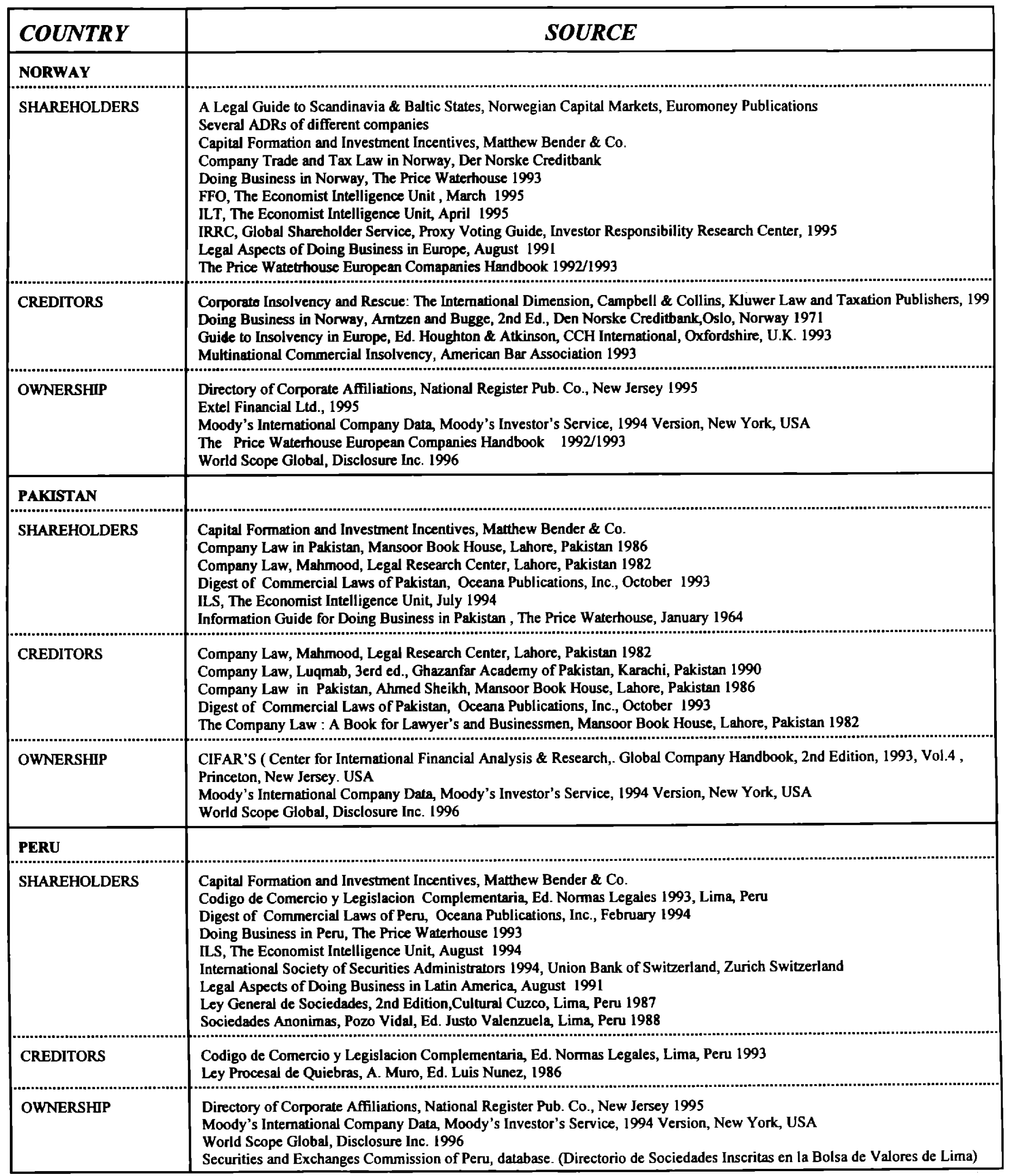




\begin{tabular}{|c|c|}
\hline COUNTRY & SOURCE \\
\hline \multicolumn{2}{|l|}{ PHILIPPINES } \\
\hline SHAREHOLDERS & $\begin{array}{l}\text { Several ADRs of different companies } \\
\text { Capital Formation and Investment Incentives, Marthew Bender \& Co. } \\
\text { Doing Business in Phillippines, The Price Waterhouse, } 1993 \\
\text { FFO, The Economist Intelligence Unit, April } 1994 \\
\text { ILT, The Economist Intelligence Unit, March } 1995 \\
\text { Law on Parnership and Corporations, Arichet, } 1986 \text { ed.Philippines } 1986 \\
\text { Legal Aspects of Doing Business in Asia and the Pacific, April } 1992 \\
\text { The Commercial Laws of Philippines, Oceana Publications, Inc., March } 1992\end{array}$ \\
\hline CREDITORS & $\begin{array}{l}\text { The Insurance Code and Insolvency Law, H. Perez, University Book Supply Inc., Manila, Philippines } 1983 \\
\text { The Insolvency Act No. } 1956 \text { of 1909, Ch. 2, 1983 }\end{array}$ \\
\hline OWNERSHIP & $\begin{array}{l}\text { Several 20F of different companies } \\
\text { CIFAR'S ( Center for Intemational Financial Analysis \& Research, Global Company Handbook, 2nd Edition, 1993, Vol.4, } \\
\text { Princeton, New Jersey. USA } \\
\text { Directory of Corporate Affiliations, National Register Pub. Co., New Jersey } 1995 \\
\text { Moody's International Company Data, Moody's Investor's Service, } 1994 \text { Version, New York, USA } \\
\text { World Scope Global, Disclosure Inc. } 1996\end{array}$ \\
\hline \multicolumn{2}{|l|}{ PORTUGAL } \\
\hline SHAREHOLDERS & $\begin{array}{l}\text { Several ADRs of different companies } \\
\text { Capital Formation and Investment Incentives, Matthew Bender \& Co. } \\
\text { Digest of Commercial Laws of Portugal, Oceana Publications, Inc., March } 1991 \\
\text { Doing Business in Portugal, The Price Waterhouse } 1993 \\
\text { FFO, The Economist Intelligence Unit, May } 1994 \\
\text { ILT, The Economist Intelligence Unit, August } 1994 \\
\text { Intemational Society of Securities Administralors 1994, Union Bank of Switzerland, Zurich Switzerland } \\
\text { Legal Aspects of Doing Business in Europe, August 1991 } \\
\text { The Price Watetrhouse European Comapanies Handbook 1992/1993 }\end{array}$ \\
\hline CREDITORS & Guide to Insolvency in Europe, Ed. Houghton \& Atkinson, CCH International, Oxfordshire, U.K. 1993 \\
\hline OWNERSHIP & $\begin{array}{l}\text { CIFAR'S ( Center for International Financial Analysis \& Research,. Global Company Handbook, 2nd Edition, 1993, Vol.4, } \\
\text { Princeton, New Jersey. USA } \\
\text { Directory of Corporate Affiliations, National Register Pub. Co., New Jersey } 1995 \\
\text { Hoover's Handbook of World Business } 1995-1996 \\
\text { Major Companies of Europe 1993/93, Graham \& Trotman, London, United Kingdom } \\
\text { The Price Waterhouse European Companies Handbook 1992/1993 } \\
\text { World Scope Global, Disclosure Inc. } 1996\end{array}$ \\
\hline \multicolumn{2}{|l|}{ SINGAPORE } \\
\hline SHAREHOLDERS & $\begin{array}{l}\text { Capital Formation and Investment Incentives, Matthew Bender \& Co. } \\
\text { Company Law, Walter C M Woon, Longman Singapore Publishers } 1990 \\
\text { Directory of Shareholders' Rights } \\
\text { Doing Business in Singapore, The Price Waterhouse } 1993 \\
\text { FFO, The Economist Intelligence Unit, September } 1994 \\
\text { ILT, The Economist Intelligence Unit, June } 1994 \\
\text { International Society of Securities Administrators 1994, Union Bank of Switzerland, Zurich Switzerland } \\
\text { IRRC, Global Shareholder Service, Proxy Voting Guide, Investor Responsibility Research Center, } 1995 \\
\text { Legal Aspects of Doing Business in Asia and the Pacific, Singapore } 1994 \\
\text { The Commercial Laws of Singapore, Oceana Publications, Inc., February } 1994\end{array}$ \\
\hline CREDITORS & $\begin{array}{l}\text { Credit and Security in Singapore, Ed. Allan, Hiscock \& Roebuck, St. Lucia, New York } \\
\text { Judicial Management in Singapore, Choong, Butterworths, Singapore } 1990 \\
\text { Sourcebook of Singapore and Malaysian Company Law, Pillaj, Singapore University Press } 1975 \\
\text { What Every Manager should Know About : Judicial Management, Tay }\end{array}$ \\
\hline OWNERSHIP & $\begin{array}{l}\text { Asian Company Handbook, 1995/1996 Edition, Toyo Keizai Inc. } \\
\text { Directory of Corporate Affiliations, National Register Pub. Co., New Jersey } 1995 \\
\text { Extel Financial Ltd., } 1995 \\
\text { World Scope Global, Disclosure Inc. } 1996\end{array}$ \\
\hline
\end{tabular}




\begin{tabular}{|c|c|}
\hline COUNTRY & SOURCE \\
\hline \multicolumn{2}{|l|}{ SOUTH AFRICA } \\
\hline SHAREHOLDERS & $\begin{array}{l}\text { Basic Company Law, Beuthin, 2nd Edition, Butterworths, South Africa } 1991 . \\
\text { Capital Formation and Investment Incentives, Matthew Bender \& Co., } 1995 \\
\text { Company Law, Benade, 4th Edition, Butterworths, Pretoria, South Africa } 1982 \\
\text { Digest of Commercial Laws of South Africa, Oceana Publications, Inc., August } 1992 \\
\text { Doing Business in South Africa, The Price Waterhouse, } 1993 \\
\text { FFO, The Economist Intelligence Unit, July 1995 } \\
\text { Honochsberg Company Act, 4th Edition, Butterworths } \\
\text { ILS, The Economist Intelligence Unit, February 1995 } \\
\text { International Society of Securities Administrators I994, Union Bank of Switzerland, Zurich Swizerland } \\
\text { IRRC, Global Shareholder Service, Proxy Voting Guide, Investor Responsibility Research Center,1995 } \\
\text { Legal Aspects of Doing Business in Africa, September } 1993\end{array}$ \\
\hline CREDITORS & $\begin{array}{l}\text { Commercial Laws in South Africa } \\
\text { Doing Business in South Africa, The Price Waterhouse, } 1993 \\
\text { The Law of Insolvency in South Africa, De la Rey, 8th Edition, Pretoria, S.A. } 1988 \\
\text { The Law of Insolvency in South Africa, C. Smith, Durban Butterworths } 1982\end{array}$ \\
\hline OWNERSHIP & $\begin{array}{l}\text { Directory of Corporate Affiliations, National Register Pub. Co., New Jersey } 1995 \\
\text { Extel Financial Ltd., } 1995 \\
\text { The Johannesburg Stock Exchange Handbook, Flesch Financial Publications, August } 1994 \\
\text { World Scope Global, Disclosure Inc. } 1996\end{array}$ \\
\hline \multicolumn{2}{|l|}{ SOUTH KOREA } \\
\hline SHAREHOLDERS & $\begin{array}{l}\text { Several ADRs of different companies } \\
\text { Capital Formation and Investment Incentives, Matthew Bender \& Co. } \\
\text { Doing Business in Korea, The Price Watehouse, } 1993 \\
\text { FFO, The Economist Intelligence Unit, February } 1995 \\
\text { ILT, The Economist Intelligence Unit, July } 1991 \text { and } 1994 \\
\text { International Society of Securities Administrators 1994, Union Bank of Switzerland, Zurich Switzerland } \\
\text { Legal Aspect of Doing Business in Asia Pacific }\end{array}$ \\
\hline \multicolumn{2}{|l|}{ CREDITORS } \\
\hline OWNERSHIP & $\begin{array}{l}\text { Asian Company Handbook, 1995/1996 Edition, Toyo Keizai Inc. } \\
\text { CIFAR'S ( Center for Intemational Financial Analysis \& Research,. Global Company Handbook, 2nd Edition, 1993, Vol.4, } \\
\text { Princeton, New Jersey. USA } \\
\text { Directory of Corporate Affiliations, National Register Pub. Co., New Jersey } 1995 \\
\text { World Scope Global, Disclosure Inc. } 1996\end{array}$ \\
\hline \multicolumn{2}{|l|}{ SPAIN } \\
\hline SHAREHOLDERS & $\begin{array}{l}\text { Several ADRs of different companies } \\
\text { Capital Formation and Investment Incentives, Matthew Bender \& Co. } \\
\text { Comentarios Practicos de la Ley de Sociedades Anonimas, J.Lanzas Galvache, Madrid } 1991 \\
\text { Digest of Commercial Laws of Spain, Oceana Publicaciones Inc, November } 1992 \\
\text { Directory of Global Shareholders Rights } \\
\text { Doing Business in Spain, The Price Waterhouse } 1993 \\
\text { FFO, The Economist Intelligence Unit, July } 1994 \\
\text { ILT, The Economist Intelligence Unic, January } 1995 \\
\text { Legal Aspects of Doing Business in Western Europe, July } 1989 \\
\text { The Price Watethouse European Comapanies Handbook } 1992 / 1993\end{array}$ \\
\hline CREDITORS & $\begin{array}{l}\text { Guide to Insolvency in Europe, Ed. Houghton \& Atkinson, CCH International, Oxfordshire, U.K. } 1993 \\
\text { Multinational Commercial Insolvency, American Bar Association } 1993\end{array}$ \\
\hline OWNERSHIP & $\begin{array}{l}\text { Directory of Corporate Affiliations, National Register Pub. Co., New Jersey } 1995 \\
\text { Extel Financial Ltd., 1995 } \\
\text { Major Companies of Europe 1993/93, Graham \& Trotman, London, Uinted Kingdom } \\
\text { Moody's Intermational Company Data, Moody's Investor's Service, 1994 Version, New York, USA } \\
\text { The Price Watetrouse European Comapanies Handbook 1992/1993, Euromoney } \\
\text { The Maxwell Espinosa Shareholder Directory, 7th Edition, 1994. S.P.A., Madrid, Espana } \\
\text { World Scope Global, Disclosure Inc. } 1996\end{array}$ \\
\hline
\end{tabular}




\begin{tabular}{|c|c|}
\hline COUNTRY & SOURCE \\
\hline \multicolumn{2}{|l|}{ SRI LANKA } \\
\hline SHAREHOLDERS & $\begin{array}{l}\text { Capital Formation and Investment Incentives, Matthew Bender \& Co. } \\
\text { Ceylon Company Law, Wickremasinghe, Tisara Press, Sri Lanka } \\
\text { Guide to the Companies Act of 1982, Jayasuriya, Asian Pathfinder Publishers \& Booksellers, Sri Lanka } 1983 \\
\text { Legal Aspects of Doing Business in Asia and the Pacific, April } 1992\end{array}$ \\
\hline \multicolumn{2}{|l|}{ CREDITORS } \\
\hline OWNERSHIP & $\begin{array}{l}\text { CIFAR'S ( Center for International Financial Analysis \& Research,. Global Company Handbook, 2nd Edition, 1993, Vol.4, } \\
\text { Princeton, New Jersey. USA } \\
\text { Handbook of Listed Companies, } 1992 \text { Edition, Colombo Stock Exchange, Colombo Sri Lanka } \\
\text { Moody's Intemational Company Data, Moody's Investor's Service, 1994 Version, New York, USA } \\
\text { World Scọpe Global, Disclosure Inc. } 1996\end{array}$ \\
\hline \multicolumn{2}{|l|}{ SWEDEN } \\
\hline SHAREHOLDERS & $\begin{array}{l}\text { Capital Formation and Investment Incentives, Matthew Bender \& Co. } \\
\text { Digest of Commercial Laws of the Commonwealth of Sweden, Oceana Publications, Inc., June } 1994 \\
\text { Doing Business in Sweden, The Price Waterhouse, } 1993 \\
\text { FFO, The Economist Intelligence Unit, October } 1994 \\
\text { ILT, The Economist Intelligence Unit, January } 1995 \\
\text { ILTM } \\
\text { International Corporate Govemance, Chapter 15, Wilhelm Luning } \\
\text { International Society of Securities Administrators 1994, Union Bank of Switzerland, Zurich Switzerland } \\
\text { IRRC, Global Shareholder Service, Proxy Voting Guide, Investor Responsibility Research Center,1995 } \\
\text { Legal Aspects of Doing Business in Westem Europe, July 1989 } \\
\text { The Price Waterthouse European Comapanies Handbook 1992/1993 }\end{array}$ \\
\hline CREDITORS & $\begin{array}{l}\text { Guide to Insolvency in Europe, Ed. Houghton \& Atkinson, CCH Intemational, Oxfordshire, U.K. } 1993 \\
\text { Cross- Border Insolvency : Comparative Dimensions, Ed. Ian F. Fletcher, UK National Committee of Comparative Law, UK } 199 \\
\text { Multinational Commercial Insolvency, American Bar Association } 1993\end{array}$ \\
\hline OWNERSHIP & $\begin{array}{l}\text { CIFAR'S ( Center for International Financial Analysis \& Research,. Global Company Handbook, 2nd Edition, 1993, Vol.4, } \\
\text { Princeton, New Jersey. USA } \\
\text { Directory of Corporate Affiliations, National Register Pub. Co., New Jersey } 1995 \\
\text { Extel Financial Ltd., } 1995 \\
\text { Major Companies of Europe 1993/93, Graham \& Trotman, London, Uinted Kingdom } \\
\text { The Price Watetrhouse European Comapanies Handbook 1992/1993, Euromoney } \\
\text { World Scope Global, Disclosure Inc. } 1996\end{array}$ \\
\hline \multicolumn{2}{|l|}{ SWITZERLAND } \\
\hline SHAREHOLDERS & $\begin{array}{l}\text { Capital Formation and Investment Incentives, Matthew Bender \& Co. } \\
\text { Digest of Commercial Laws of the Commonwealth of Switzerland, Oceana Publications, Inc., March } 1991 \\
\text { Doing Business in Switzerland, The Price Waterhouse, } 1993 \\
\text { FFO, The Economist Intelligence Unit, October } 1994 \\
\text { ILT, The Economist Intelligence Unic, October } 1994 \\
\text { Intemational Society of Securities Administrators 1994, Union Bank of Switzerland, Zurich Switzerland } \\
\text { IRRC, Global Shareholder Service, Proxy Voting Guide, Investor Responsibility Research Center,1995 } \\
\text { Legal Aspects of Doing Business in Europe, August 1991 } \\
\text { Shareholders Rights Abroad, Stephen M. Davis, Investor Responsibility Research Center } \\
\text { The Price Watethouse European Comapanies Handbook } 1992 / 1993\end{array}$ \\
\hline CREDITORS & $\begin{array}{l}\text { Guide to Insolvency in Europe, Ed. Houghton \& Atkinson, CCH Intemational, Oxfordshire, U.K. } 1993 \\
\text { European Bankruptcy Laws, Ed. Botwinik and Weinrib, American Bar Association, USA 1986 } \\
\text { Intemational Loan Workouts and Bankuptcies, Sponsored by Section of Corporate, Banking and Business Law and the Divisio } \\
\text { for Professional Education, American Bar Association, USA } 1987 \\
\text { Multinational Commercial Insolvency, American Bar Association } 1993\end{array}$ \\
\hline
\end{tabular}




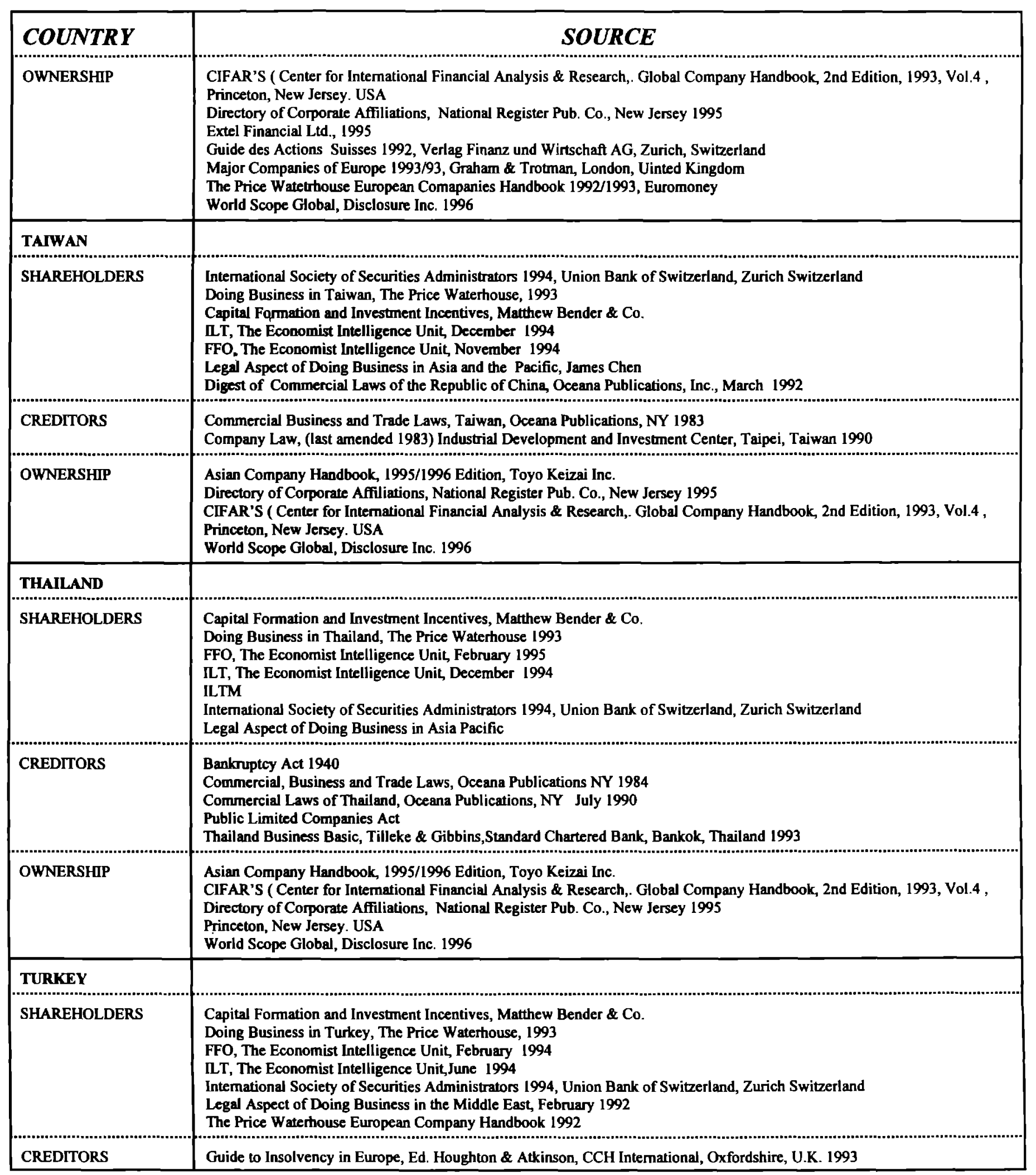




\begin{tabular}{|c|c|}
\hline COUNTRY & SOURCE \\
\hline OWNERSHIP & $\begin{array}{l}\text { Directory of Corporate Affiliations, National Register Pub. Co., New Jersey } 1995 \\
\text { Guide to Investment in Turkey, Global Investor 1993, Euromoney Publications, London } 1993 \\
\text { The Price Watetrhouse European Comapanies Handbook 1992/1993, Euromoney } \\
\text { CIFAR'S ( Center for Intemational Financial Analysis \& Research,. Global Company Handbook, 2nd Edition, 1993, Vol.4, } \\
\text { Princeton, New Jersey. USA } \\
\text { Moody's International Company Data, Moody's Investor's Service, } 1994 \text { Version, New York, USA } \\
\text { World Scope Global, Disclosure Inc. } 1996\end{array}$ \\
\hline \multicolumn{2}{|l|}{ U.K. } \\
\hline SHAREHOLDERS & $\begin{array}{l}\text { Several ADRs of different companies } \\
\text { Capital Formation and Investment Incentives, Matthew Bender \& Co. } \\
\text { Digest of Commercial Laws of England and Wales, Oceana Publications, Inc., August } 1994 \\
\text { Directory of Global Shareholders } \\
\text { Doing Business in the United Kingdom, The Price Waterhouse, } 1993 \\
\text { European Company Laws, Drury and Xuereb, Chapter } 7 \text { \& 9, Dartmouth, England } 1991 \\
\text { FFO, The Economist Intelligence Unit, August } 1994 \\
\text { ILT, The Economist Intelligence Unit, October } 1991 \\
\text { ILTM } \\
\text { Intemational Corporate Govemance, Overview of UK corporate govemance, Anne Simpson } \\
\text { Intemational Society of Securities Administrators } 1994 \text {, Union Bank of Switzerland, Zurich Switzerland } \\
\text { IRRC, Global Shareholder Service, Proxy Voting Guide, Investor Responsibility Research Center, 1995, } \\
\text { Legal Aspects of Doing Business in Western Europe, July 1989 } \\
\text { Shareholders Rights Abroad, Stephen M. Davis, Investor Responsibility Research Center } \\
\text { The Price Watetrhouse European Comapanies Handbook 1992/1993 }\end{array}$ \\
\hline CREDITORS & $\begin{array}{l}\text { Compositions in Bankruptcy, Dalhuisen, A.W. Sijthoff-Leyden, The Netherlands } 1968 \\
\text { Corporate Bankruptcy and Reoganization Procedures in OECD and Central and Eastem European Countries, OECD, Paris, } \\
\text { France } 1994 \\
\text { Guide to Insolvency in Europe, Ed. Houghton \& Atkinson, CCH International, Oxfordshire, U.K. } 1993 \\
\text { Cross- Border Insolvency : Comparative Dimensions, Ed. Ian F. Fletcher, UK National Committee of Comparative Law, UK } 199 \\
\text { European Bankruptcy Laws, Ed. Botwinik and Weinrib, American Bar Association, USA } 1986 \\
\text { Intemational Loan Workouts and Bankruptcies, Sponsored by Section of Corporate, Banking and Business Law and the Divisio } \\
\text { for Professional Education, American Bar Association, USA } 1987 \\
\text { Multinational Commercial Insolvency, American Bar Association } 1993\end{array}$ \\
\hline OWNERSHIP & $\begin{array}{l}\text { Several } 20 F \text { of different companies } \\
\text { CIFAR'S ( Center for Intemational Financial Analysis \& Research,. Global Company Handbook, 2nd Edition, 1993, Vol.4, } \\
\text { Directory of Corporate Affiliations, National Register Pub. Co., New Jersey } 1995 \\
\text { Extel Financial Ltd., } 1995 \\
\text { Moody's Intemational Company Data, Moody's Investor's Service, } 1994 \text { Version, New York, USA } \\
\text { Princeton, New Jersey. USA } \\
\text { The Price Watethouse European Comapanies Handbook 1992/1993, Euromoney } \\
\text { World Scope Global, Disclosure Inc. } 1996\end{array}$ \\
\hline \multicolumn{2}{|l|}{ URUGUAY } \\
\hline SHAREHOLDERS & $\begin{array}{l}\text { Capital Formation and Investment Incentives, Marthew Bender \& Co. } \\
\text { Commercial Laws of Uruguay } \\
\text { Doing Business in Uruguay, the Price Waterhouse } 1993 \\
\text { ILTM } \\
\text { ILT, The Economist Intelligence Unit, April I995 } \\
\text { Ley de Sociedades Comerciales, Ferro and Olivera, La Realidad Nacional, Montevideo, Uruguay } 1989 \\
\text { Sociedades Comerciales, Rippe, Fundacion de Cultura Universitaria, 1st Edition, Montevideo, Uruguay } 1989\end{array}$ \\
\hline CREDITORS & $\begin{array}{l}\text { Quiebras Derecho Comercial, Nuria Rodriguez, Ed. Universidad Ltda, Montevideo, Uruguay } 1988 \\
\text { Ley de Sociedades Comerciales, Ferro and Olivera, La Realidad Nacional, Montevideo, Uruguay } 1989 \\
\text { Sociedades Comerciales, Rippe, Fundacion de Cultura Universitaria, lst Edition, Montevideo, Unguay } 1989 \\
\text { El Derecho Comercial, el Derecho de Cambio, el Derecho de Quiebra y el Derecho de Comercio Maritimo del Uruguay, Garcia } \\
\text { Acevedo, London } \\
\text { Cross-Border Insolvency:national and Comparative Studies, I. Fletcher, JCM Mohr Tubingen } 1992\end{array}$ \\
\hline OWNERSHIP & $\begin{array}{l}\text { Hoppenstedt Affiliations and Corporate Structures } \\
\text { Moody's Intermational Company Data, Moody's Investor's Service, } 1994 \text { Version, New York, USA }\end{array}$ \\
\hline
\end{tabular}




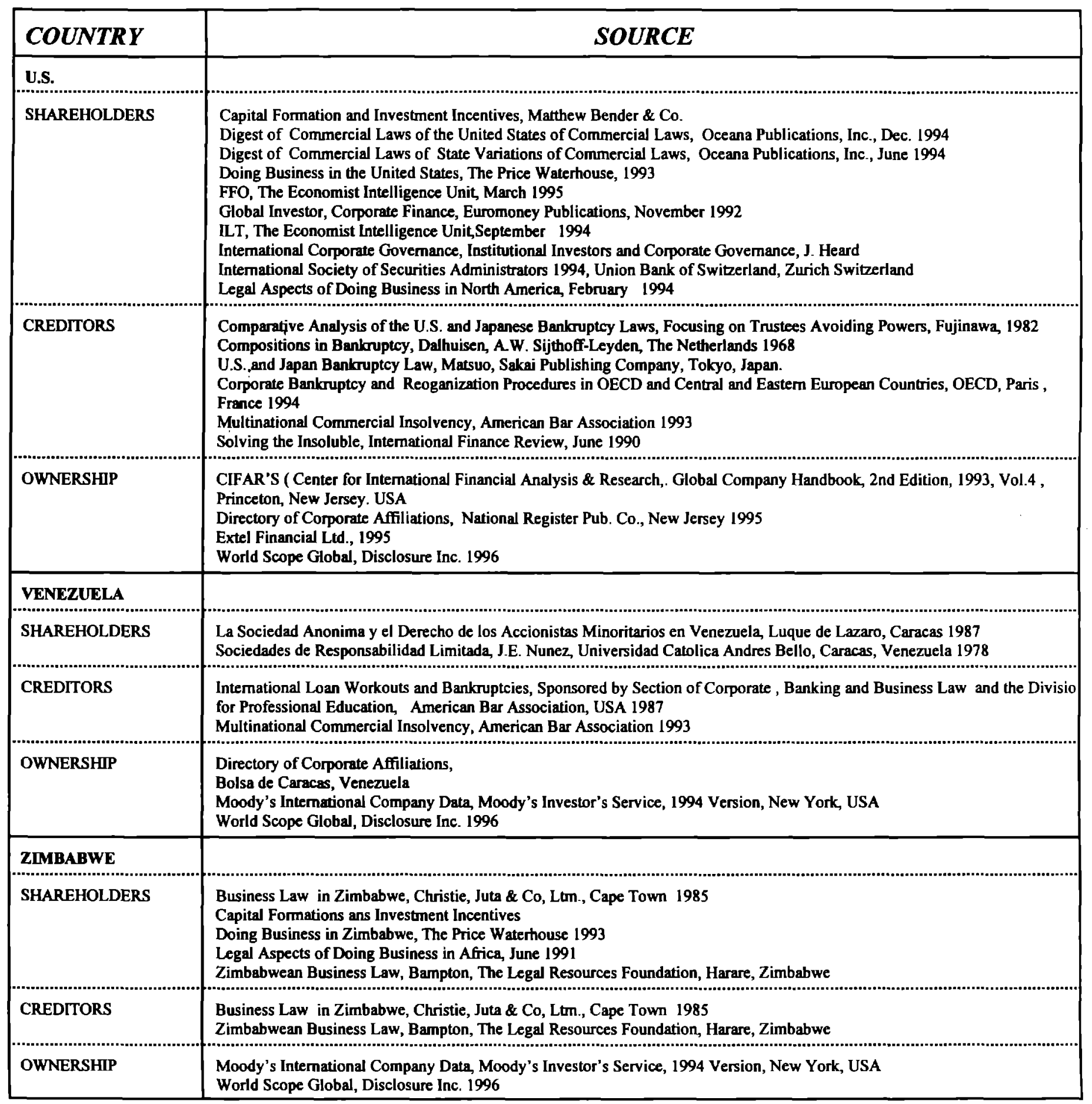




\section{OTHER GENERAL SOURCES:}

Asian Company Handbook, 1995/1996 Edition, Toyo Keizai Inc.

CIFAR'S ( Center for International Financial Analysis \& Research,. Global Company Handbook, 2nd Edition, 1993, Vol.4, Princeton, New Jersey. USA

Corporate Bankruptcy and Reoganization Procedures in OECD and Central and Eastern European Countries, OECD, Paris , France 1994

Corporate Governance, Monks and Minow, Blackwell Business, USA 1995

Cross- Border Insolvency : Comparative Dimensions, Ed. Ian F. Fletcher, UK National Committee of Comparative Law, UK 1990

Directory of Corporate Affiliations, National Register Pub. Co., New Jersey 1995

European Bankruptcy Laws, Ed. Botwinik and Weinrib, American Bar Association , USA 1986

Extel Financial Ltd., United Kingdom, 1995

Guide to Insolvency in Europe, Ed. Houghton \& Atkinson, CCH International, Oxfordshire, U.K. 1993

Hoppenstedt Affiliation Corporate Structures, Germany, 1995

Intemational Financial Statistics, Intemational Monetary Funds, February 1996

International Loan Workouts and Bankruptcies, Sponsored by Section of Corporate, Banking and Business Law and the Division for Professional Education, American Bar Association, USA 1987

International Corporate Finance, Robert 1. Tricker, Chapters 2, 3, 4, \& 8, Simon \& Schuster, Singapore 1994

Main Economic Indicators, OECD, January 1996

Major Companies of Europe 1993/94, Graham \& Trotman, London, Uinted Kingdom

Major Companies of the Arab World 1994/95, 18 th Edition, Graham \& Trotman, London, United Kingdom.

Minority Shareholders' Rights, Robin Hollington, 2nd Edition, Sweet \& Maxwell, London, U.K. 1994

Moody's International Company Data, Moody's Investor's Service, 1994 Version, New York, USA

Multinational Commercial Insolvency, American Bar Association 1989 and 1993, Wisconsin, USA

Shareholder Rights Abroad, A Handbook for the Global Investor, Stephen M. Davis, Investor Responsability Research Center, 1989

Social Indicators of Development 1991-92, World Bank, John Hopkins University Press 1992

The Price Watetrhouse European Comapanies Handbook 1992/1993, Euromoney

Who Owns Whom 1995/96, Dun \& Bradstreet International, Bucks, United Kingdom

World Development Report 1993, Investing in Health, World Bank, Oxford Press University 1993

World Tables, World Bank 1995, John Hopkins University Press

World Scope Global, Disclosure Inc. 1996 